\title{
ARTESANATO DE CAIXETA EM SÃO SEBASTIÃO - SP
}

\section{HEIDI CRISTINA BUZATO DE CARVALHO}

Bacharel em Ciências Sociais

Dissertação apresentada à Escola Superior

de Agricultura "Luiz de Queiroz",

Universidade de São Paulo, para obtenção

do título de Mestre em Ciências. Área de

Concentração: Ciências Florestais.

PIRACICABA

Estado de São Paulo - Brasil

Dezembro - 2001 


\section{ARTESANATO DE CAIXETA EM SÃO SEBASTĨ̃O - SP}

\section{HEIDI CRISTINA BUZATO DE CARVALHO}

Sociólogo

Orientador: Prof. Dr. Dalcio Caron

Dissertação apresentada à Escola Superior de Agricultura "Luiz de Queiroz", Universidade de São Paulo, para obtenção do título de Mestre em Ciências. Área de Concentração: Ciências Florestais.

PIRACICABA

Estado de São Paulo - Brasil

Dezembro - 2001 
Dados Internacionais de Catalogação na Publicação (CIP) DIVISÃO DE BIBLIOTECA E DOCUMENTAÇÃO - ESALQ/USP

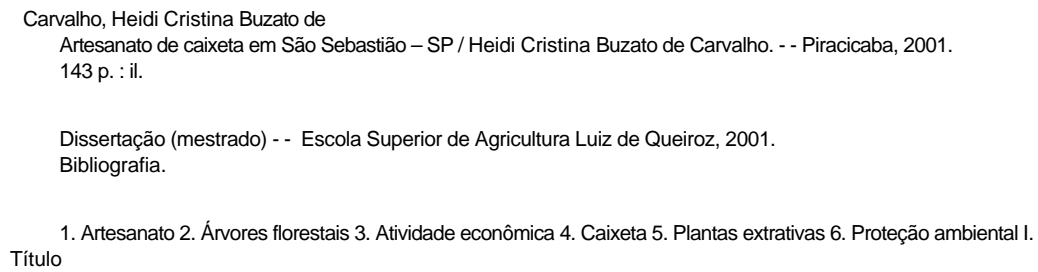

CDD 634.97354

"Permitida a cópia total ou parcial deste documento, desde que citada a fonte - $\mathrm{O}$ autor" 
Dedico esse estudo às minhas filhas Ana Luiza e Maria Olivia 


\section{SUMÁRIO}

Página

LISTA DE QUADROS …................................................................... VI

LISTA DE FIGURAS …..................................................................... VIII

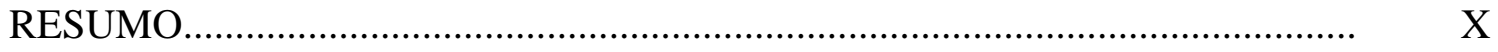

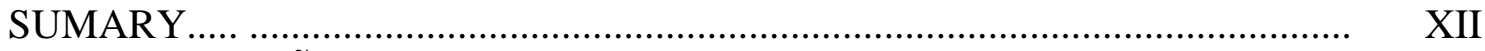

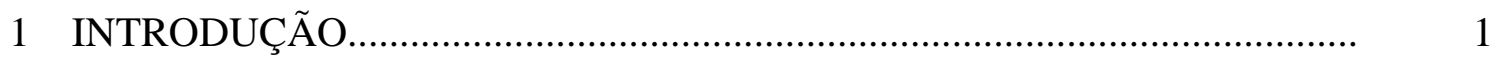

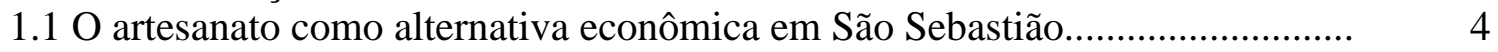

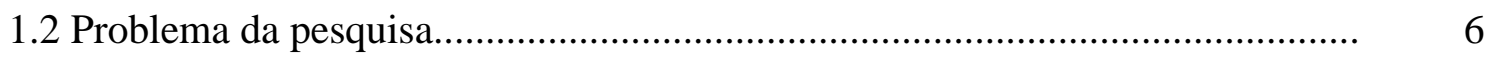

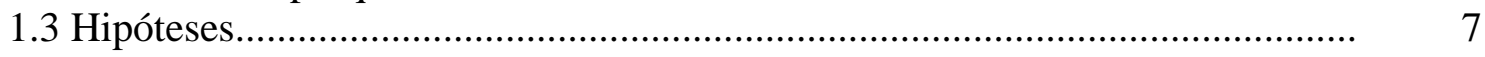

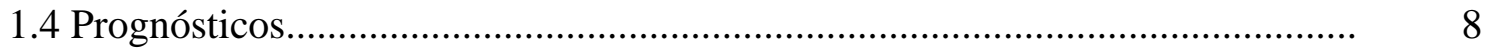

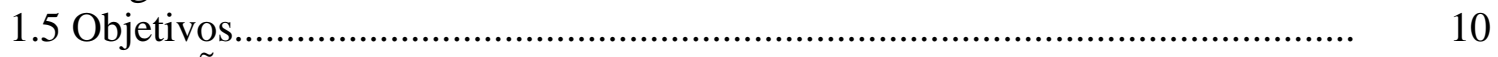

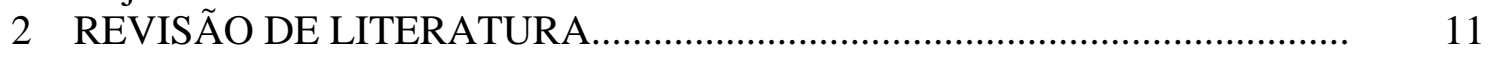

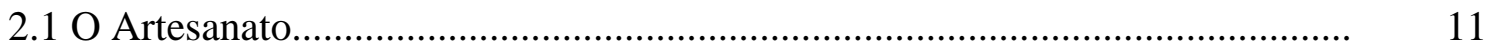

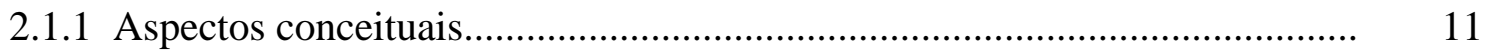

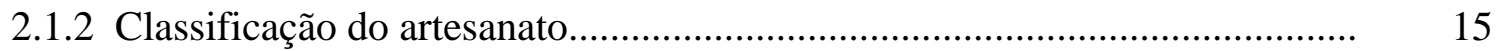

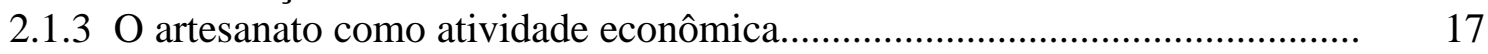

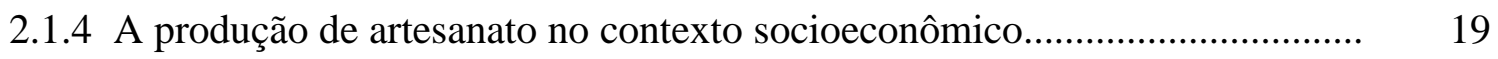

2.1.5 O artesanato nas comunidades tradicionais............................................... 20

2.1.6 Modo-de-produção artesanal e manufatura.................................................... 21

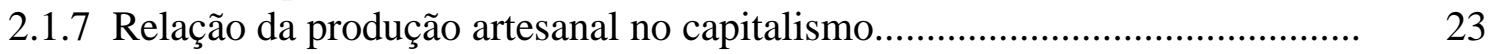

2.2 A cultura Caiçara......................................................................................... 28

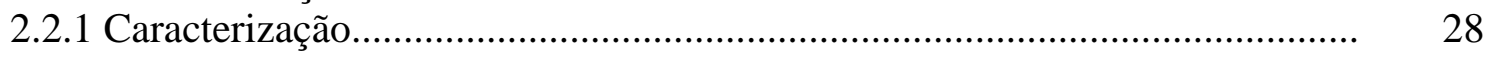

2.2.2 Cultura tradicional frente às transformações.................................................. 32

2.3 A Caixeta - Tabebuia Cassinoides (Lam) DC................................................. 35

3 PROCEDIMENTOS METODOLÓGICOS...................................................... 42

3.1 São Sebastião - caracterização do município.................................................... 49

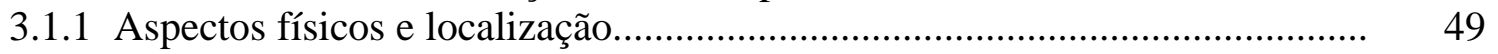

3.1.2 Histórico do município de São Sebastião.................................................... 49

3.2 Silveiras - caracterização do município........................................................ 52

3.2.1 Aspectos físicos e localização............................................................... 52

3.2.2 Histórico do município de Silveiras....................................................... 52 


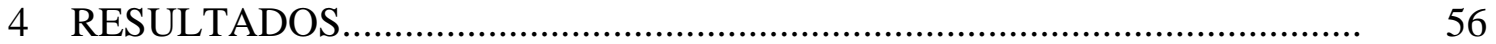

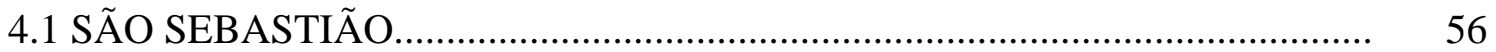

4.1.1 A cultura material dos caiçaras de São Sebastião......................................... 56

4.1.2 O surgimento do artesanato popular ........................................................... 62

4.1.3 Potencial de desenvolvimento da atividade............................................... 71

4.1.4 A organização dos artesãos......................................................................

4.1.5 Caracterização socioeconômica do artesão.................................................. 76

4.1.5.1 Aspectos gerais.................................................................................. 76

4.1.5.2 Aspectos particulares.............................................................................. 81

4.1.6 Produção e Comercialização....................................................................... 85

4.1.6.1 Matéria-prima.................................................................................... 85

4.1.6.2 Processo de produção - processamento da madeira ..................................... $\quad 90$

4.1.6.3 Comercialização.................................................................................... 92

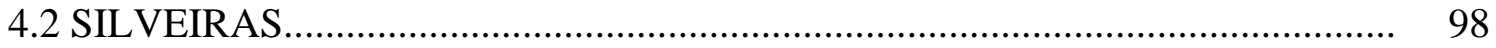

4.2.1 A implantação do artesanato em Silveiras........................................................ 98

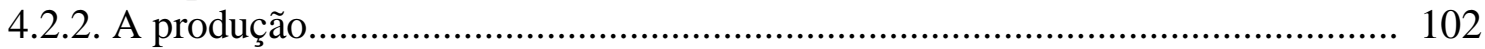

4.2.3 Caracterização do artesão, relações de trabalho e renda...................................... 105

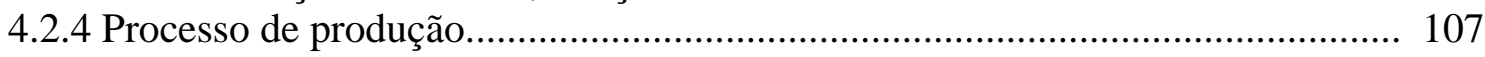

4.2.4.1 Locais de produção............................................................................... 107

4.2.4.2 Etapas da produção............................................................................... 107

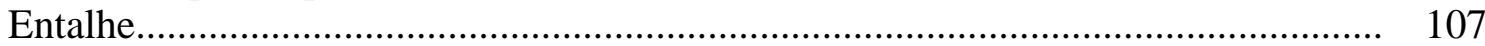

Corte

Lixa.

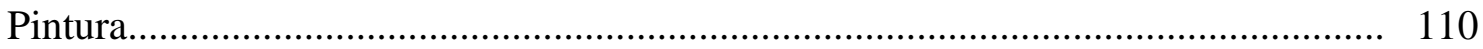

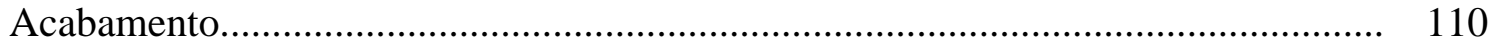

4.1.5 Matéria-prima da produção....................................................................... 113

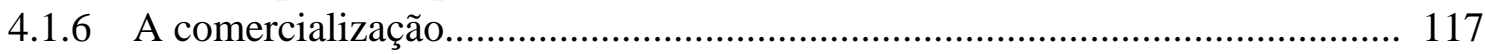

4.1.6.1 Formas de comercialização...................................................................... 118

4.1.6.2 Estratégias de comercialização.................................................................. 119

4.1.7 Criação, cópia e direito........................................................................... 122

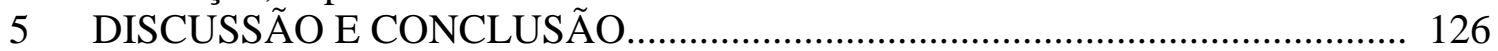

5.1 Produção tradicional X produção capitalista....................................................... 127

5.2 O artesão e o artesanato no contexto de mercado.................................................. 128

5.3 Fatores internos condicionantes da produção de artesanato................................... 129

5.3.1 Aspectos ambientais e legais - o suprimento da matéria-prima..................... 130

5.3.2 Aspectos sociais - a organização dos artesãos e as intervenções de instituições externas............................................................................... 131

5.3.3 Aspectos econômicos - produção e comercialização........................................ 133

5.3.4 Aspectos políticos - políticas públicas........................................................ 134

5.4 Artesanato: expressão cultural X mercadoria.................................................... 135

6 REFERÊNCIAS BIBLIOGRÁFICAS.......................................................... 138 


\section{LISTA DE QUADROS}

Página

1 Caixetais de São Sebastião - situação de manejo e área estimada.......................... 38

2 Áreas de ocorrência da caixeta na região sudeste do Brasil................................. 39

3 Número de entrevistados em cada município e ano do levantamento..................... 45

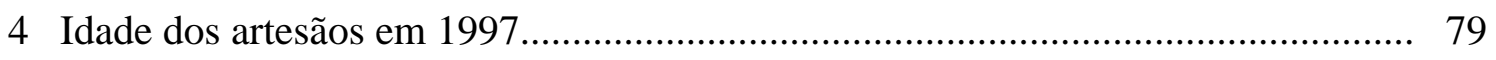

5 Renda dos artesãos em 1997/1999/2000.......................................................... 80

6 Artesãos consultados em 1997/1999/2000.................................................... 85

7 Formas de obtenção da caixeta nos anos 1997/1999/2000 ................................... 86

8 Dificuldades assinaladas pelos artesãos em 1997/1999/2000_............................. 87

9 Preço dos produtos em São Sebastião............................................................ 92

10 Locais de venda de artesanato em 1997/1999/2000.......................................... 94

11 Faturamento mensal/ número de unidades de produção........................................ 103

12 Tempo de constituição do empreendimento.................................................. 104

13 Número de trabalhadores envolvidos nas unidades pesquisadas...................... 105

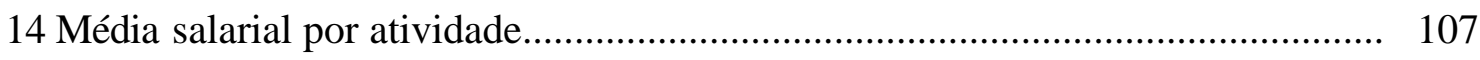

15 Valor pago por peça nas etapas de produção.................................................... 111

16 Preço dos produtos em Silveiras............................................................... 112 
17 Número de produtores por madeira utilizada................................................ 114

18 Consumo de madeira por mês.................................................................. 114

19 Número de produtores/origem da caixeta................................................. 114 


\section{LISTA DE FIGURAS}

Página

1 Localização dos municípios de São Sebastião e Silveiras...................................... 42

2 Primeiros passarinhos produzidos em São Sebastião............................................. 67

3 Mexedores de bebidas com passarinhos........................................................... 67

4 Chaveiros de peixe..................................................................................... 67

5 Peixe para pendurar na parede.................................................................. 67

6 Dona Luzia e as flores que criou...................................................................... 69

7 Flores criadas por dona Sebastiana.................................................................... 70

8 Helicônias do Lindomar.................................................................................. 70

9 Linda faz artesanato em sua casa..................................................................... 70

10 Distribuição dos artesãos por matéria-prima em 1990......................................... 77

11 Distribuição dos artesãos por matéria-prima em 1997........................................ 77

12 Loja na casa do artesão, produtos próprios e revenda........................................ 96

13 Loja de artesanato no centro da cidade ……………….................................... 96

14 Tucano feito por um dos irmãos Carvalho....................................................... 105

15 Entalhe na unidade de produção................................................................... 108

16 Entalhe feito em casa............................................................................. 108

17 Corte de tábuas................................................................................. 108

18 Riscando as peças............................................................................. 108 


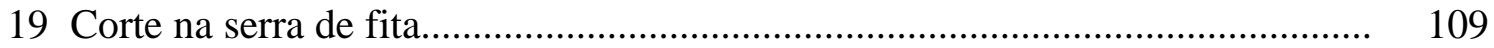

20 Peça cortada à máquina..................................................................................... 109

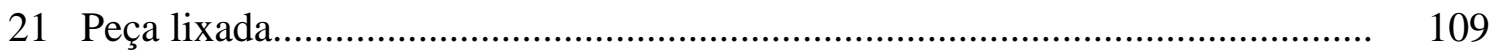

22 Lixa feita à máquina.................................................................................... 109

23 Pintura das peças............................................................................... 110

24 Colocação de ganchos no acabamento.......................................................... 110

25 Entrega de caixeta para João Camilo.................................................................. 116

26 Armazenagem usual ............................................................................. 116

27 Secagem das peças em varais...................................................................... 116

28 Armazenamento de toras feito por João Camilo.................................................. 116

29 Local de venda de produtos em Silveiras........................................................... 121

30 A diferença na qualidade dos produtos.............................................................. 123 


\title{
O ARTESANATO DE CAIXETA EM SÃO SEBASTIÃO
}

\author{
Autora: HEIDI CRISTINA BUZATO DE CARVALHO \\ Orientador: Prof. Dr. DÁLCIO CARON
}

\section{RESUMO}

$\mathrm{O}$ artesanato de caixeta -Tabebuia Cassinoides (LAM.) DC - existente no município de São Sebastião/SP foi criado pelos artesãos locais durante a década de 80 como resultado do turismo instalado na região, do conhecimento das técnicas de entalhe em madeira dos artesãos caiçaras e da disponibilidade do recursos natural existente no município. Com a diminuição das áreas de ocorrência da caixeta, devido à urbanização crescente, à venda da terra pelos artesãos e a legislação restritiva ao corte da caixeta, o artesanato produzido com essa matéria-prima perdeu a base de sua produção e vem desaparecendo no decorrer desses últimos anos. Esse estudo iniciourse com objetivo de identificar e analisar os fatores de sustentabilidade da produção de artesanato local. Ao longo do processo de levantamento de dados foi observada a existência da produção de artesanato de caixeta em sistema de manufatura no município de Silveiras. Esse sistema foi organizado por produtores locais no fim dos anos 80, em decorrência do artesanato produzido em São Sebastião. A produção foi mecanizada e criaram-se estratégias de comercialização eficientes, distribuindo esse artesanato em todo o país e no exterior. Os produtos se aprimoraram, diversificaram e se transformaram, passando a influenciar os padrões e o próprio sistema de produção do artesanato de São Sebastião. Os dados para 
essa pesquisa foram obtidos através de fontes secundárias e pesquisa de campo, em que foram realizadas entrevistas abertas, estruturadas e semi-estruturadas, questionários e conversas informais. Os dados dos dois sistemas de produção foram comparados, possibilitando, com isso, uma análise das condições de sustentabilidade da produção em São Sebastião. As conclusões desse estudo apontaram para as condições internas de sustentabilidade da produção em São Sebastião, limitadas, principalmente, pela pequena oferta da caixeta. Por outro lado, o artesanato tradicional se transformará para alcançar o consumidor da sociedade moderna. Enquanto produto de relações sociais, econômicas e culturais específicas, o artesanato sofre, necessariamente, transformações, à medida em que passam a existir relações com 0 mercado. 


\section{THE HANDCRAFT WITH “CAIXETA” IN SÃO SEB ASTIÃO \\ Author: HEIDI CRISTINA BUZATO DE CARVALHO Adviser: Prof. Dr. DÁLCIO CARON}

\section{SUMARY}

The handcraft with "caixeta" - Tabebuia Cassinoides (Lam) DC - that exists in the city of São Sebastião, in São Paulo, Brazil, was created by the local craftsmen during the decade of the eighties as a result from the tourism started in the region, from the knowledge of the wood carving techniques of the "caiçaras" craftsmen and from the availability of the natural resources in the region. As the areas where the "caixeta" grows are diminishing due to the growing urbanization, the selling of land by the craftsmen and the restrictive legislation about the cutting of this wood, the craft produced with the "caixeta" lost the base of its production and has been disappearing in the last years. This study began with the aim of identifying and analyze the factors of sustainability of the production of the local craft. As data was being collected, it was noticed the existence of production of craft with Tabebuia cassinoides in a system of manufacture in the city of Silveiras SP. This system was organized by local producers at the end of the eighties due to handcraft produced in São Sebastião. The production was mechanized and they created efficient commercialization strategies, distributing this craft in the whole country and abroad. The products were improved, diversified and transformed, getting to influence the patterns and even the craft producing system in São Sebastião. Data for this research was obtained 
through secondary sources and field research, by which open, structured and halfstructured interviews; questionaries and informal talks were 


\section{INTRODUÇÃo}

A derrubada de florestas tem sido responsável por grande parte dos danos ao meio ambiente. Entre eles pode-se citar a extinção de espécies animais e vegetais, erosão, compactação do solo, destruição dos ciclos de nutrientes, além dos fatores associados como a poluição das águas, mudanças climáticas, etc. $\mathrm{O}$ alarme causado pelo impacto do corte de florestas tem colocado na pauta de discussões a importância de buscar opções em outros modos alternativos de utilização das florestas. O ponto de partida é a necessidade de utilizar um recurso para valorizá-lo e evitar sua destruição. Para Posey (s/d), a utilização e conservação da diversidade biológica e ecológica está sendo atualmente destruída, em parte, pela falta de conhecimento do potencial econômico de espécies nativas para remédios, alimentos etc. Segundo ele, os povos tradicionais, com seus conhecimentos, podem ajudar-nos a usufruir desse imenso potencial, necessitando, para isso, que suas culturas sobrevivam.

Pesquisadores e estudiosos se empenham em demonstrar e confirmar a contribuição das sociedades tradicionais na ampliação e manutenção da diversidade biológica. Assim, a discussão atual sobre a biodiversidade está intimamente ligada à diversidade de culturas e as suas formas particulares de uso dos recursos naturais (Isabelle Vidal Giannini MARI/USP citada por Ribeiro, B.1995, Balleé,W, 1993, Diegues, 1993, Posey, D.A.,1983).

As populações que habitam áreas naturais e possuem uma intensa relação de dependência com o meio natural passaram a ser chamadas populações tradicionais, cujo conceito varia entre pesquisadores, governos e profissionais que trabalham com essas populações(Diegues, 1994; Adams, 2000). 
Os recursos naturais das florestas formam a base da cultura material dessas populações que tem seu modo de vida intrinsecamente ligado ao meio natural. $\mathrm{O}$ número de espécies usadas por essas populações é muito grande. Muitos autores já trataram do assunto, organizando, citando, enumerando as diferentes espécies e seus usos para alimentação, cura de doenças, ornamentos, rituais, indumentária, utensílios domésticos, para caça e pesca, venenos e muitos outros ( Lévi-Strauss, 1987; Elisabetsky, 1987; Posey, s/d; Ribeiro, 1992; Sanches, 1997)

Behr (1994) salienta que as populações tradicionais através de suas práticas econômicas, entre elas o artesanato, vêm contribuindo para a manutenção dos ecossistemas onde vivem. Essas populações necessitam de organização social e garantia de seus direitos sobre os recursos naturais. Segundo o autor, a criação de Reservas Extrativistas é uma forma de integrar as populações tradicionais na gestão dos recursos naturais, distribuir benefícios sociais e contribuir para o desenvolvimento sustentável. Ele acrescenta que " a diversificação das atividades econômicas nas Reservas e a eficiente comercialização são essenciais para diminuir a atual dependência do extrativismo. Essa diversificação pode ser alcançada pela introdução de novos produtos no mercado - como as plantas medicinais e o incentivo a sistemas agro-florestais, à apicultura, à piscicultura, artesanato, etc.”.

Atualmente, o desenvolvimento das comunidades tradicionais requer estratégias para o uso diversificado dos recursos naturais nos ecossistemas em que vivem. Assim, a produção de artesanato surge como uma forma de geração de renda a partir do uso de um recurso natural. Segundo Berta Ribeiro (1984), a produção de artesanato para o mercado pode oferecer ao artesão tradicional a oportunidade de exercer uma atividade à qual está acostumado e que faz parte de seu patrimônio cultural. A Autora diz ainda que a produção de artesanato para o mercado pode inibir a saída do artesão da comunidade para alugar sua força de trabalho como trabalhador braçal, além de proporcionar a confraternização dos homens e das mulheres nas horas de trabalho artesanal coletivo e lhes garantir uma renda que possa ser superior à que aufeririam como empregados de ínfima categoria nos empreendimentos regionais. 
Por outro lado, a produção de artesanato para o comércio pode promover uma série de transformações dentro das comunidades, como alertam Canclini (1984) e Ribeiro(1987), principalmente em relação à divisão do trabalho entre os sexos, além de exercer uma pressão maior sobre um recurso natural. Tais fatores devem ser considerados sempre que a produção de artesanato esteja em questão, considerando-se os aspectos particulares de cada caso.

Diegues (1992) chama atenção para a noção de que o desenvolvimento implica no equacionamento dos modos particulares, históricos e culturais, e de relações entre as pessoas com os ecossistemas em que vivem, criando-se assim, a possibilidade de construção de sociedades sustentáveis.

$\mathrm{O}$ uso dos recursos naturais passa por uma questão de ordem política que é a garantia ao direito de uso. Diferentes movimentos de populações extrativistas culminaram na garantia de direitos dessas populações à exploração dos recursos naturais dos quais dependem. Tais movimentos e organizações comunitárias tem promovido iniciativas de manejo sustentado de recursos naturais, alterando os padrões tradicionais de relação política com os centros de poder e com instâncias de intermediação, possibilitando a emergência de lideranças e o fortalecimento da organização social (Almeida, 1995, p.17) .

Almeida (1995) discorre sobre o Movimento das Quebradeiras de Côco Babaçu, cuja identidade emergiu a partir da construção das condições efetivas de "conquista da terra, autonomia do processo produtivo e do local de moradia, formas de organização político-organizativas que asseguram o livre acesso aos babaçuais e capacidade mobilizatória permanente como pré-requisito para o êxito das iniciativas cooperativistas"(Almeida, 1995, p.19).

Nos anos 80, um importante movimento social culminou na criação de uma alternativa para o desenvolvimento de regiões tropicais. As Reservas Extrativistas (RESEX) foram criadas para atender a uma necessidade dos seringueiros da decadente indústria da borracha. Segundo Viana (1992), as RESEX possuem muitos desafios a enfrentar para consolidarem-se. Entre eles a diversificação da base econômica, o 
aumento da produtividade, a melhoria do sistema de comercialização e industrialização local dos produtos da floresta.

\subsection{O artesanato como alternativa econômica em São Sebastião}

O litoral norte paulista, composto pelos municípios de Ubatuba, Caraguatatuba, São Sebastião e Ilhabela, caracterizou-se pelo desenvolvimento de uma cultura típica resultante da mistura do europeu, do índio e dos negros a partir das condições naturais e ambientais da região. Nas décadas de 50, 60 e 70, essa população e o ambiente natural sofreram as consequências de uma ocupação desenfreada, proporcionada pela abertura de estradas que deram acesso à região. Essa nova forma de ocupação passou a predominar no local sem que houvesse uma preocupação com o ambiente natural e cultural que ali se encontravam. A população residente era vista como a vendedora da terra e os ecossistemas locais como espaço a ser transformado para o lazer e para o lucro.

Tal processo gerou conflitos entre os caiçaras, habitantes dessas localidades, e os novos ocupantes da terra, o poder público e as autoridades encarregadas de fazer cumprir a legislação ambiental (São Sebastião/PCSSTA,1997).

Com a falta de iniciativas públicas em relação a essa ocupação os ecossistemas locais foram duramente afetados com a urbanização desorganizada, aumento da população, produção de lixo, ocupação de áreas inapropriadas para edificação, entre outros. Para a população local esse foi o início da desorganização de suas relações sociais, econômicas e culturais, que, uma vez ficando sem a terra, perdeu junto suas fontes de sobrevivência, seu trabalho, e, consequentemente sua cultura fortemente arraigada ao ambiente litorâneo.

O turismo, novo vetor do desenvolvimento local, provocou a venda das posses da terra e um impacto cultural sem precedentes ao implantar uma nova ordem econômica e sócio-cultural através da introdução de novos padrões de consumo, 
novas relações de trabalho, novas formas de lazer, debilitando ainda mais as instituições da cultura caiçara.

A população caiçara local, em sua maioria, ficou excluída dos benefícios oriundos desse ciclo de turismo, inserindo-se, na maioria da vezes, como mão-de-obra barata e sujeita às flutuações da oferta de empregos, condicionada pela sazonalidade das temporadas. Esse mesmo processo trouxe para os municípios locais um contingente grande de migrantes para a construção civil, que, atualmente, disputa empregos, espaços de moradia e serviços públicos em geral com os caiçaras e suas famílias.

No município de São Sebastião, tal processo de implantação do turismo permitiu que surgisse uma pequena produção de artesanato comercial como atividade econômica, em decorrência de uma atividade tradicional, a produção do artesanato utilitário. Essa atividade chegou a atingir um número significativo de pessoas ( cerca de 90 pessoas cadastradas pela prefeitura local) durante os anos de 1989, 1990 e 1991, mas hoje encontra-se muito reduzida, tendendo a desaparecer. Nessa ocasião foram identificados artesãos que trabalhavam com diferentes produtos madeireiros e nãomadeireiros oriundos das florestas locais, para o feitio de cestos gamelas, pilões, canoas e tantos outros.

O artesanato produzido com a caixeta (Tabebuia cassinoides) é um dos que sofre maior controle devido às restrições ao uso desse recurso e é também o objeto desse estudo.

O processo de urbanização da região diminuiu drasticamente a quantidade da caixeta disponível no local. Por outro lado, a venda das posses de terra pelos caiçaras tirou-lhes o direito de acesso às áreas com os remanescentes dos caixetais.

Com a legislação ambiental vigente, a caixeta passou a sofrer restrições para o corte, ficando condicionada a um Plano de Manejo, que é um instrumento técnico que possibilita a exploração do recurso. Tais Planos são caros pois exigem o trabalho de um técnico especializado. Com isso, os artesãos ficam impossibilitados de adquirir a caixeta e fazem-no à revelia da lei, para seu prejuízo e prejuízo do caixetal. Com a falta da caixeta toda a produção fica comprometida e o artesão fica desestimulado. 
Esse fator, aliado às dificuldades de acesso a novos mercados, competição com produtos similares a preços mais baixos, vem ocasionando a desestruturação da atividade. A perda dessa atividade pelos caiçaras representa a perda de uma alternativa econômica criada por eles mesmos num contexto extremamente favorável ao seu desenvolvimento. $\mathrm{O}$ do artesanato poderia representar uma alternativa para a conservação dos ecossistemas locais onde ocorrem os caixetais, frente à única forma de ocupação que vem sendo utilizada, ou seja, o corte dos caixetais para a construção civil.

Por outro lado, o artesanato é uma atividade que cria uma identidade, ainda que fraca, entre os artesãos caiçaras, porque caracteriza o artesão como um caiçara, que se reconhece e é reconhecido como tal por seus pares. Os artesãos caiçaras de São Sebastião têm como desafio garantir seu espaço físico e o uso dos recursos naturais locais em bases sustentáveis, gerando renda e melhoria na sua qualidade de vida.

Nos anos 80, a produção de artesanato de caixeta foi iniciada por comerciantes e produtores do município de Silveiras/SP, com a introdução da mecanização, incremento nas estratégias de produção e comercialização, entrando no mercado com produtos a preços baixos, nele interferindo e prejudicando a pequena produção oriunda do litoral. Esses produtos podem ser comprados nas lojas de artesanato de São Sebastião e de todo o litoral de São Paulo, do Brasil, interior e capital dos Estados e no exterior. As estratégias de mercado desses produtores é bastante agressiva e é um forte competidor com o produto de São Sebastião.

Tal fato representa uma tendência do mercado de absorver produtos de diferentes origens, de comunidades tradicionais, indígenas e outras, reelaborá-los e massificá-los, estabelecendo, nessas comunidades, novos mecanismos para a produção, transformando o produto e as relações de produção dentro das comunidades.

\subsection{Problema da Pesquisa}

A produção de artesanato de caixeta em São Sebastião é uma atividade realizada sob um sistema de produção que não tem sustentabilidade devido a vários fatores, o que impossibilita a integração entre o acesso ao recurso natural, a produção e a 
comercialização. Dessa forma a produção fica condicionada a fatores sazonais internos ou externos, ocasionando perda de renda e da possibilidade de conservação da caixeta no município.

Torna-se necessária a análise e compreensão desse sistema de produção, comparando-o com outras experiências, afim de se identificar os fatores para a sustentabilidade da produção.

\subsection{Hipóteses}

A sustentabilidade da produção de artesanato de caixeta em São Sebastião está condicionada aos seguintes fatores:

\section{(i) Ambientais}

- Urbanização crescente das áreas onde localizam-se os caixetais, ocasionando o seu desaparecimento.

\section{(ii) Legais}

- Os caixetais permaneceram durante muitos anos como áreas de coleta de espécies ou de caça para os caiçaras tradicionais. Com o turismo essas áreas foram vendidas e os artesãos não têm mais a posse da terra. $\mathrm{O}$ acesso à caixeta ficou muito restringido.

- A extração da caixeta está regulamentada por lei com exigência de Plano de Manejo. Os artesãos não tem condições para custear a elaboração de um Plano de Manejo.

\section{(iii) Sociais}

- Dificuldade de gerenciamento da produção com vistas a alcançar uma produção em uma escala que gere renda suficiente e constante 
- Os artesãos não possuem uma organização que os agregue e defenda seus interesses,

(iv) Culturais

- A entrada dos produtos similares de Silveiras diminuiu ainda mais o mercado local para os produtos locais

- A atividade é desvalorizada, tanto por não gerar renda significativa para a maioria dos artesãos, como pela presença de um conjunto de valores, em que o produto industrializado é mais valorizado, e a cultura aiçara faz parte do passado.

(v) Econômicos

- Os artesãos não estão capacitados para a auto-gestão da produção e não possuem controle do processo produtivo, ocasionando em baixa produtividade,

- O sistema de produção é desarticulado e necessita de um modelo que leve em consideração a oferta do recurso natural, a capacidade produtiva do grupo e a comercialização.

- Não há estratégia eficiente de comercialização para todos os artesãos.

(vi) Políticos

- A falta e ineficiência de políticas públicas nos níveis municipal e estadual não cria condições para o desenvolvimento da atividade.

\subsection{Prognósticos}

(i) A falta de caixeta é um dos fatores que limitam a produção de artesanato. Os caixetais são ameaçados pela urbanização crescente e encontram-se em propriedades particulares. A falta de um planejamento para o uso do solo que proteja os caixetais e a falta de interesse dos proprietários para a sua 
conservação, coloca os últimos caixetais sob o risco de total desaparecimento em virtude de ocuparem áreas de grande interesse para a construção.

(ii) Na prática, a regulamentação para o corte da caixeta, impossibilita o acesso do artesão à caixeta. A inexistência do manejo sustentável da caixeta e o fato do artesão não ser o dono das áreas onde localiza-se a caixeta, faz com que ele a extraia ilegalmente, ou passe a usar outros materiais, descaracterizando seu produto. Se, por um lado a legislação tem impedido o uso da caixeta para o artesanato, por outro, ela não tem conseguido evitar o corte raso de caixetais para grandes empreendimentos imobiliários.

(iii) A falta de organização dos artesãos não possibilita que eles se fortaleçam como grupo de interesses ou organizem o processo de produção, garantindo acesso à caixeta do local ou de outras fontes fornecedoras (ex: Vale do Ribeira), controlando a produção (custos, volume de materiais utilizados, planejamento) e promovendo uma comercialização eficiente.

(iv) Com a entrada dos produtos de Silveiras, o artesão local deixa de fazer seu artesanato e passa a copiar o artesanato de Silveiras, ou, simplesmente, revendêlo.

(v) Sem capacidade de gerir sua produção o artesão não melhora sua produtividade, não resolve a falta da caixeta e não articula a produção com a comercialização A falta de estratégias de comercialização restringe o mercado ao âmbito local, que é pequeno e sazonal. Poucos artesãos tem acesso a outros mercados. O artesanato 
de Silveiras faz forte concorrência com o artesanato local e confundem-se com ele.

(vi) Sem uma política que integre a questão ambiental, o uso e ocupação do solo e o desenvolvimento social, nos diferentes níveis de governo, os grupos que dependem de recursos naturais, como artesãos e pescadores, têm suas atividades de subsistência e/ou econômicas, em alguns casos, impedidas ou desestruturadas, além da constante ameaça de degradação dos ecossistemas de onde retiram os recursos naturais.

\subsection{Objetivos}

\section{Geral}

Esse estudo tem como objetivo fazer uma análise do sistema de produção de artesanato de caixeta em São Sebastião, comparando-a ao sistema de produção do município de Silveiras e avaliando suas condições de sustentabilidade, através da identificação de seus pontos vulneráveis e de seus potenciais.

\section{Específicos}

(i) Realizar um estudo de caso da produção de artesanato em São Sebastião para identificação dos fatores limitantes e das potencialidades.

(ii) Realizar um estudo de caso do sistema de produção de Silveiras; caracterizar e analisar sua base, visando realizar uma análise comparativa entre os dois sistemas. 


\section{REVISÃO DE LITERATURA}

\subsection{O Artesanato}

A bibliografia disponível sobre o tema aborda situações distintas em diferentes regiões do país e de outros países, sem, contudo, realizar um estudo aprofundado voltado para questões que envolvam as relações sociais, culturais e econômicas e o meio ambiente nas comunidades que tem o artesanato como alternativa de trabalho dentro do mercado mais abrangente.

Alguns autores tratam da produção artesanal e suas relações com o mercado capitalista e suas transformações a partir dessas relações.

\subsubsection{Aspectos Conceituais}

Pereira (s/d), estudioso do artesanato, discorre em diferentes trabalhos sobre as questões que envolvem o artesanato, alertando sobre a dificuldade em conceituá-lo, pois o termo é vago e impreciso para definir o artesanato enquanto sistema de produção. $\mathrm{Na}$ tentativa de classificá-lo enquanto atividade de produção de bens, o autor interpõe o artesanato entre a "Arte Popular" e a "Pequena Indústria", permutando características e manifestações entre uma e outra. Segundo o autor o artesanato constitui um sistema de produção à parte da indústria, porém com ela vai se confundindo ou sendo confundido fazendo surgir termos como "artesanato-industrial" ou "indústria artesanal" (Pereira, s/d) 
O autor acrescenta ainda que, apesar do emprego de tais expressões, o artesanato representa muito bem a cultura material de pequenas comunidades e que por estar

"de maneira fundamental subordinado à ecologia - a abundância local de determinada matéria-prima condicionando a formação do núcleo obreiro, e tantas outras relações entre a Terra e o Homem que ele centraliza - por certo, há de apoiar-se em arraigada tradição" (Pereira, s/d: p.9).

E segue dizendo, a respeito das condições de existência e manutenção desse artesanato, que:

“Na razão direta com que atuem as forças dessa função ecológica e a intensidade desse cunho tradicional variará a resistência do artesanato às influências modificadoras de sua feição; isto é, a tradição de trabalho faz com que subsistam vestígios de sua existência, mesmo quando ele já se encontra superado pelo poderio econômico da indústria. São estes vestígios as formas de Arte-Popular” (Pereira, s/d: p.9).

Pereira(s/d) faz a distinção entre o artesanato e a arte popular, dizendo que esta não visa atender, originariamente, a nenhuma finalidade econômica ou a uma satisfação imediata duma necessidade social, mas satisfaz aos impulsos de uma manifestação estética, embora seja eventualmente comercializada, enquanto que o artesanato raz inerente em si o interesse do comércio imediato. Artesanato e arte-popular identificamse pela fonte de produção - o povo e sua tradição - e distinguem-se nos seus fins (Pereira, s/d). 
Com relação à distinção entre artesanato e pequena-indústria diz o autor que o principal elemento diferenciador entre artesanato e a pequena-indústria é o processo de divisão do trabalho:

"Enquanto no artesanato esse processo se baseia em disposições de ordem fisiológica e psicológica, isto é, através duma formação profissional orientada no sentido de determinado ofício, à base de um aprendizado feito no próprio exercício da “arte”; na indústria, essa mesma divisão se filia a imperativos de ordem tecnológica estabelecida pela máquina” (Pereira, s/d: 12).

Pereira (s/d) alerta também para uma tendência que, embora não seja obrigatória, é uma tendência lógica, de que

"quando um núcleo de atividade artesanal opera alheio a influências capazes de lhe modificar as condições de existência e é favorecido por especiais situações de mercado, a sua valorização econômica há de levá-lo, rápida ou lentamente, a maiores possibilidades de atendimento ao consumo, para transformá-lo, mais cedo ou mais tarde, numa pequena-indústria” (Pereira, s/d: 13).

Segundo Pereira(1979), a atividade artesanal, pode ser considerada um fato econômico por estar inserida no campo do trabalho e constituir um problema de produção. O autor delineia uma conceituação operacional:

"atividade do tipo industrial, predominantemente manufatureira, executada em oficina (doméstica ou não) de equipamento primário e acentuado manualismo, em 
que indivíduos de ocupação qualificada se encarregam, pessoalmente ou mediante auxiliares, sem relação empregatícia, de todas ou quase todas as fases de transformação da matéria-prima em produtos acabados, os quais se destinam à comercialização e devem, conforme o caso, se caracterizar por um maior ou menor grau de originalidade ou de tipicidade” (Pereira, 1979: p.79).

Servetto et al. (1998) cita vários autores e estudos sobre a produção de artesanato na região andina da Argentina, dos quais ressalta a tendência de se definir o objeto artesanal e o artesão como produtor do objeto, descontextualizando suas condições de trabalho e sua história. Assim, encontra as seguintes definições que caracterizam o artesanato tradicional:

- $\quad$ Trabalho predominantemente manual

- Utilização de recursos naturais locais

- Conhecimentos transmitidos pelas gerações passadas

- $\quad$ Caráter utilitário e funcional da obra

- Bagagem cultural plasmada na criação individual

- $\quad$ Expressão de uma cultura e fator de identidade

A autora parte de uma análise das relações que se estabelecem entre os sujeitos sociais envolvidos no processo de produção de artesanato, nas dimensões econômicas, sociais, culturais e políticas presentes no arcuito produção-circulação-consumo. $\mathrm{O}$ conceito de estratégias de sobrevivência utilizado em seu estudo é entendido como a articulação do conjunto de mecanismos, comportamentos e relações empreendidas para viabilizar um objetivo fundamental, alcançar a reprodução integral da unidade doméstica nas melhores condições possíveis, isto é, alcançar um nível de satisfação das 
necessidades básicas. O conceito foi restringido à sua dimensão econômica - às estratégias de obtenção de renda.

As conclusões desse estudo apontam a importância da produção artesanal como atividade complementar na renda das famílias locais e ressaltam a importância da articulação dos três sujeitos sociais envolvidos: os artesãos, suas associações e o Estado, na viabilidade econômica de desenvolvimento da atividade (Servetto et al.,1998).

\subsubsection{Classificação do artesanato}

Em pesquisas realizadas para o Mapeamento do Artesanato Paranaense foi proposta a seguinte classificação:

1. Artesanato Popular - a obra feita à mão, baseada em motivos tradicionais e que se transmite, de geração a geração, com a utilização da matéria-prima regional.

2. Artesanato Artístico - expressa de alguma maneira o sentimento estético individual de um autor com forte presença do imaginário e de caráter utilitário.

3. Artesanato Utilitário - produz artigos sem caracterização artística especial, de uso cotidiano na comunidade.

4. Trabalhos Manuais - objetos confeccionados a partir de materiais diversos. Geralmente obedecem a receitas ou moldes e são facilmente copiados. Podem ser utilitários ou decorativos.

5. “Industrianato"- objetos cuja matéria-prima é industrializada e sua produção é feita em série, utilizando, na maioria das vezes, moldes, formas ou máquinas. A criação pode ser direcionada por ondas temporárias de consumo. Sua cópia pode ser praticada, por não possuir 
identidades que garanta sua originalidade. Podem ser utilitários ou decorativos (Paraná,SEASC, 1994: 5).

Pereira (s/d) classifica as atividades artesanais, dividindo-as em áreas distintas de acordo com a finalidade dos produtos. Assim tem-se:

- $\quad$ Artesanato Utilitário - compreende os bens de utilização direta para a vida, face aos condicionamentos do meio.

- Artesanato Artístico - compreende os bens de utilização acessória, decorativa ou ornamental

- $\quad$ Artesanato Misto - compreende os bens resultantes da combinação do artesanato utilitário com o artístico, onde as manifestações das atividades aparecem confundidas no produto, no uso ou na ativação.

- Artesanato da Manutenção - compreende as ocupações auxiliares da produção e os serviços de atendimento direto ao consumidor, cujo produto é o resultado obtido com a atividade. (Pereira,1979: 85).

Dentro das iniciativas públicas existe um Decreto Federal - Decreto no 80.098, de 08 de agosto de 1977 - que instituiu o Programa Nacional de Desenvolvimento do Artesanato - PNDA, 77, com o objetivo de coordenar, estimular e desenvolver as atividades artesanais no país, melhorando o padrão de vida do artesão, ampliação de oportunidades de trabalho e a conservação de valores culturais através do trabalho. $\mathrm{O}$ PNDA considera que o artesanato é:

- A atividade predominantemente manual de produção de um bem que requeira criatividade elou 
habilidade pessoal, podendo ser utilizadas ferramentas $e$ máquinas

- $\quad$ O produto ou bem resultado da atividade acima referida

- $O$ resultado da montagem individual de componentes, mesmo anteriormente trabalhados e que resulta em novo produto.

Nesse estudo serão utilizados as classificações de Artesanato Utilitário, como sendo aquele produzido visando suprir as necessidades de subsistência do grupo que o produz, utilizado pelos pesquisadores do Paraná/SEASC (1994) e por Pereira (s/d). O uso dessa classificação justifica-se apenas para situar o momento na cultura tradicional ( caiçaras de São Sebastião) em que eram produzidos objetos cuja finalidade era o uso da comunidade. Para as demais referências ao artesanato será utilizada a classificação de Artesanato Popular (Paraná/SEASC, 1994) por abranger a idéia de obra feita à mão, baseada em motivos tradicionais e utilização da matéria-prima regional. A noção de Artesanato Popular também será usada nesse estudo, como o artesanato feito para ser comercializado, em contraposição ao Artesanato Utilitário.

Essa classificação que procura distinguir os produtos prendem-se à característica dos produtos, à matéria-prima, ao uso do produto, à forma como foi concebido. Tais diferenças podem combinar-se num conjunto muito maior de possibilidades e classificações. Como os objetivos desse estudo são identificar os fatores de sustentabilidade da produção e entender como as relações sociais de produção de artesanato se transformam a partir das relações entre a produção e o mercado, essa classificação será utilizada para identificar situações e momentos distintos desse processo, sem ater-se às diferenças específicas do produto.

\subsubsection{O artesanato como atividade econômica}


O artesanato é uma atividade que pode ser analisada nas suas dimensões histórica, econômica, social, cultural e ambiental. Através do artesanato, o homem satisfez e ainda satisfaz demandas essenciais e acessórias do seu meio social e econômico, no tocante à obtenção de bens manufaturados.

Pereira (1979) enfatiza que, para ser eficientemente compreendido, o artesanato não pode ser apenas encarado como um conjunto de técnicas e processos dirigidos à produção de bens manufaturados, mas na reciprocidade das relações com o meio em que se expande, ou seja, dentro do contexto cultural que, num determinado momento, geram as condições que lhe dão origem e existência.

Pode-se dizer que muitos materiais e técnicas surgiram da adaptação dos grupos ao meio ambiente e em decorrência de sua organização social. Segundo Canclini (1984) tais materiais e técnicas estão em constante readaptação frente às condições econômicas e culturais, aos estímulos e recursos disponíveis.

Antonio Cândido (1987:25) reforça essa colocação ao dizer que " para cada sociedade, num determinado momento, há uma equação necessária entre o ajuste ao meio e a organização social”.

Pereira (1979), discorre sobre a história e evolução do artesanato como sistema de produção. Segundo analisa, o artesanato caracteriza-se como um complexo de atividades de natureza industrial, isto é, pela transformação de matérias-primas em produtos acabados. A produção de artesanato, tradicionalmente, ocorre no âmbito das famílias, com o suprimento das necessidades da mesma, em situação bastante próxima da auto-suficiência.

Da produção doméstica voltada para o autoconsumo, iniciou-se a expansão da produção e a divisão do trabalho. $\mathrm{O}$ aprimoramento profissional deu origem ao artesão propriamente dito, que, ao aprimorar-se transformou-se em mestre. Esse mestre estabelecia-se com uma oficina definindo, assim, seu ofício; na oficina repassava seu saber a um aprendiz ( Pereira, 1979).

Esse sistema, característico da Idade Média, atingiu seu mais alto grau de importância social com as Corporações de Ofícios, com objetivos de auxílio mútuo e aperfeiçoamento técnico. Com o alargamento dos mercados locais para os nacionais em 
decorrência da criação dos Estados modernos surgiu a figura do intermediário, que entrou no cenário econômico como negociante e consumidor exclusivo, restringindo pouco a pouco a independência do mestre. Esse negociante passou a fornecer a matériaprima e terminou por ceder-lhe os instrumentos de trabalho. Não detendo mais a propriedade dos bens de produção, o mestre perdeu sua autonomia na medida em que passou para a condição de empregado desse negociante, agora empresário. Surgiu assim a manufatura. Nesse sistema o artesão conservou apenas a característica de trabalhar em casa. Posteriormente, com a necessidade de aumentar e melhorar a produtividade, o empresário passou a reunir no mesmo local de trabalho os artífices de igual ofício, implantando a primeira forma organizada de concentração da mão-de-obra. No século XVIII, com a Revolução Industrial, a manufatura evoluiu e surgiu a fábrica (Pereira, 1979).

\subsubsection{A produção de artesanato no contexto socioeconômico}

No estudo sobre o artesanato no Paraná, afirmam os pesquisadores, que, o artesão, enquanto trabalhador e produtor, está inserido na estrutura econômica de uma sociedade e que, essa inserção possui importância diferenciada de acordo com a sociedade em questão. Mesmo que diferentes sociedades possuam um sistema econômico semelhante, o papel do pequeno agricultor ou do artesão, por exemplo, varia de uma para outra e também, em uma mesma sociedade ao longo do tempo (Paraná/SEASC,1994).

Segundo Parente (1994), o artesanato constitui uma das respostas colocadas para o problema do desemprego, concretizando-se na revitalização de atividades econômicas tradicionais, constituindo numa estratégia de ocupação intensiva de mão-de-obra, dinamização de mercados locais, preservação de valores culturais, ampliação dos conhecimentos acerca das características e valores locais, regionais e nacionais, favorecendo a criação de identidades no plano internacional. Segundo o autor, o artesanato funciona ainda como instrumento de ocupação produtiva, gerando renda, 
fixando o homem no campo, evitando o êxodo rural, intensificando trocas culturais e comerciais entre os países, incentivo ao turismo e conservação do meio ambiente (Parente, 1994).

Para D’Ávila (1983), o artesanato está diretamente ligado à questão do emprego, como solução de curto prazo para os países em desenvolvimento. $\mathrm{O}$ estímulo à produção artesanal requer baixos investimentos, dando chances a uma imensa parcela da população à participação econômica efetiva. Para o autor a importância do processo de produção artesanal reside ainda no resgate de valores humanos - habilidades pessoais, subjetividade, criatividade, liberdade de produção, autonomia, beleza - em contraposição aos processos industriais - de mecanização e automação. $\mathrm{O}$ autor ressalta o alto valor agregado do produto artesanal, e sua condição para penetrar em países onde os produtos manufaturados têm o melhor mercado (D’Ávila, 1983).

Pereira (1979) analisa algumas das funções do artesanato que dinamizam fluxos de melhoria econômica e social. Entre elas, cita que o artesanato proporciona mais emprego e produção com menos dispêndio de capital, tornando-se, por isso, importante fator de fomento social e econômico; é a um só tempo meio de subsistência e fator de equilíbrio no mercado de trabalho; é tradicionalmente um complemento básico da economia rural; responde por todo um sistema informal de capacitação de mão-de-obra; é uma força viva do potencial turístico; é um estímulo e uma resposta para a promoção social através do trabalho; representa não apenas um aspecto da memória cultural de um povo mas também se faz um instrumento de valorização de seus instrumentos materiais (Pereira, 1979).

Tais considerações, de modo geral, abordam o artesanato como um setor da economia que gera empregos e dinamiza os fluxos econômicos. Esse aspecto do artesanato pode ser observado em diferentes situações, no incremento da economia rural como estratégia de sobrevivência da agricultura familiar (Couto, 1998), no contexto de cidades turísticas e outros. Embora, não se enfatize, nesse estudo, esse aspecto, observarse-á, que, para os artesãos de São Sebastião o artesanato representa, fundamentalmente, a possibilidade de emprego e renda.

\subsubsection{Artesanato nas comunidades tradicionais}


Nas comunidades tradicionais, onde o artesanato possui um caráter utilitário, por princípio, ele não se constitui como objeto de troca ou venda, mas como um produto voltado para o suprimento das necessidades da comunidade.

Diegues (1994) aponta que o artesanato típico das comunidades caiçaras habitantes de uma porção específica do litoral brasileiro tem uma origem na colonização do país. Essas atividades artesanais foram se diversificando e se desenvolvendo como um complexo de trabalho relativamente orgânico à medida em que se expandiam os núcleos populacionais da Colônia. O autor enfatiza que, nessas comunidades tradicionais, os produtores independentes estão envolvidos em atividades econômicas de pequena escala, como agricultura e pesca, coleta e artesanato.

Dessa forma a produção de artesanato que se encontra junto a essas comunidades possui algumas características específicas. Primeiramente, o artesanato encontra-se no âmbito da produção familiar, com pequena especialização do trabalho, e vincula-se à razão determinante da disponibilidade da matéria-prima encontrada no local ( Diegues, 1994).

\subsubsection{Modo-de-produção artesanal e manufatura}

Com a finalidade de entender o modo-de-produção artesanal e suas relações com o mercado mais abrangente, esse estudo compreenderá uma abordagem dos conceitos de valor-de-uso, valor de troca, modo-de-produção e manufatura utilizados por Marx (1982).

Marx (1982) define o valor-de-uso de uma mercadoria como a utilidade daquele bem, que constitui o seu conteúdo material. $O$ valor-de-troca, encontra-se na relação quantitativa entre valores-de-uso de espécies diferentes, na proporção em que se trocam. Uma mercadoria possui seu valor-de-troca a partir de seu valor-de-uso somado ao tempo de trabalho humano, definido socialmente, cristalizado na mercadoria.

O conceito de modo-de-produção combina as característica intrínsecas de um tipo de unidade produtiva e sua articulação com a formação socioeconômica em que está 
inserida. Assim, tem-se o artesanato como um modo-de-produção onde predominam as características internas da produção, isto é, as técnicas, a matéria-prima, a divisão do trabalho por sexo, o tempo utilizado para a produção, que definem o produto e sua forma de produção, e as características externas à produção, suas relações com a sociedade abrangente, relações de compra e venda, interferências desse mercado na produção, resignificação do produto.

Marx (1982) faz um estudo sobre o surgimento da manufatura como modo-deprodução, colocando seu surgimento com a decomposição da atividade do artesão, cujo trabalho abrangia o processo de produção como um todo.

De acordo com o autor, o princípio característico da manufatura é a divisão do trabalho, e sua reorganização através da cooperação, isto é, trabalhadores de vários ofícios e independentes são concentrados numa mesma oficina e o produto final passa pelas mãos de todos os artesãos. O produto final, "a mercadoria, deixa de ser produto individual de um artífice independente que faz muitas coisas, para se transformar no produto social de um conjunto de artífices, cada um dos quais realiza ininterruptamente a mesma e única tarefa parcial (Marx, 1982, p.388)”.

A manufatura, que no início era a combinação de vários ofícios independentes, se transforma, progressivamente, num sistema de produção com a divisão especializada de diversas operações, "onde cada operação se cristaliza em função exclusiva de um trabalhador e sua totalidade é executada pela união desses trabalhadores parciais ( Marx, 1982, p.387)”.

A manufatura se origina e se forma a partir do artesanato. Ela surge, de um lado, da combinação de ofícios independentes que perdem sua independência e se tornam tão especializados que passam a constituir operações parciais do processo de produção, e de outro, tem suas origem na cooperação de artífices de determinado ofício, decompondo o ofício em suas diferentes operações particulares. Na manufatura, cada função é executada separadamente, mas ocorre simultaneamente.

A manufatura caracteriza-se pela presença do trabalho manual, artesanal, dependendo da força, da habilidade, rapidez e segurança do trabalhador individual, para manejar seu instrumento. "O ofício continua sendo a base". 
Com a manufatura ganha-se força produtiva em relação ao artesanato, cuja vantagem advém de seu caráter cooperativo geral e da especialização do trabalhador que passa a realizar uma única tarefa, diminuindo o tempo necessário para sua realização.

$\mathrm{Na}$ manufatura estabelece-se o princípio da diminuição do tempo de trabalho necessário para a produção de mercadorias, utilizando-se máquinas, eventualmente, para processos simples e de larga escala. Nesse processo desenvolvem-se diferentes funções para o trabalhador, estabelecendo uma hierarquia nas forças de trabalho, no grau de formação profissional, criando valores diversos e diferentes salários (Marx, 1982).

\subsubsection{Relação da Produção Artesanal no Capitalismo}

Canclini (1984) considera que os bens culturais de um determinado grupo surgem das necessidades globais de um sistema social e por ele está determinado, ou seja, existe sempre uma organização material própria para cada produção cultural. Tais bens culturais, entre eles o artesanato, sejam de comunidades tradicionais ou das classes populares rurais e urbanas, são manifestações de sua cultura popular.

Entretanto, o autor entende que as culturas populares inseridas no contexto mais abrangente da sociedade capitalista são o resultado de uma interação com essa sociedade, cuja relação caracteriza-se por uma apropriação desigual do capital cultural, pela elaboração específica das suas condições de vida e pela interação conflituosa com os setores hegemônicos.

Assim, o autor sugere que o artesanato deve ser estudado dentro de um contexto mais amplo, dentro da sociedade abrangente em que é produzido, em suas relações com o sistema econômico vigente e em suas diferentes etapas: a produção, a circulação e o consumo. $\mathrm{O}$ autor afirma que "é necessário estudar o artesanato como um processo e não como um resultado, como produtos inseridos em relações sociais e não como objetos voltados para si mesmos” (1984, p. 51).

Para Canclini (1984) tais fatos devem ser entendidos na relação entre a cultura hegemônica e a cultura subalterna. As classes subalternas, grupos e comunidades 
culturalmente distintos, são vistos como portadores de uma diversidade cultural considerada inferior, estática e dissociada da realidade atual. O artesanato, produto dessas camadas, grupos e comunidades, é valorizado pelo seu exotismo, que nas lojas urbanas de artesanato, nos museus, na publicidade e no turismo, é resignificado. $\mathrm{O}$ sentido e o valor popular são reelaborados nas relações sociais.

$\mathrm{O}$ autor avalia que a cultura hegemônica incorpora a cultura popular pois necessita dessa diferença para firmar sua superioridade e para sua própria expansão. Segundo Canclini (1984), na relação entre a cultura popular e o capitalismo, este apropria-se dessa cultura popular, reestruturando-a, reorganizando o significado e a função dos seus objetos, suas crenças e práticas através do reordenamento da produção e do consumo. Ocorre uma desestruturação das culturas nacionais, étnicas e de classe e sua posterior reorganização num sistema unificado de produção simbólica onde a base econômica e as representações culturais já não fazem parte de um todo e fica rompida a unidade entre a produção, a circulação e o consumo, bem como entre os indivíduos e a comunidade.

Canclini (1984) diz ainda que um objeto é produzido, numa comunidade/sociedade tradicional, pelo seu valor-de-uso, é vendido no mercado pelo seu valor-de-troca e é comprado por um turista estrangeiro pelo seu valor estético.

Os produtos artesanais, que possuem a função tradicional de suprir as necessidades do grupo, modificam-se ao se relacionarem com o mercado capitalista, o turismo, a indústria cultural e as formas modernas de arte, comunicação e lazer. Tal processo de transformações torna o artesão mais frágil pois desloca seu poder de decisão sobre o quê, como e quando produzir, para a esfera da comercialização. O consumo e o próprio consumidor passam a definir o que é comercialmente vendável, introduzindo novas demandas e necessidades de renovação (Canclini, 1984).

Para Canclini (1984) a multinacionalização do capital e, consequentemente, a transnacionalização da cultura, impõem uma troca desigual dos bens materiais e simbólicos. As comunidades tradicionais, grupos étnicos e as classes populares, chamados por Canclini de culturas subalternas, são obrigados a subordinar sua organização econômica e cultural aos mercados nacionais, de acordo com uma lógica 
monopolística. Nessa relação, a produção e o consumo dessas classes e culturas subalternas, assim como sua estrutura social e sua linguagem própria são reordenados, com a finalidade de se adaptarem ao desenvolvimento capitalista.

Segundo Braverman (1981) na forma econômica que antecede ao capitalismo monopolista, a família era a unidade de produção e consumo dos bens da comunidade. Com a transformação dos produtos em mercadorias, o mercado passa a ser o intermediador das relações humanas e da vida social. Diz o autor que

“ é na era do monopólio que o modo capitalista de produção recebe a totalidade do indivíduo, da família e das necessidades sociais e, ao subordiná-los ao mercado, também os remodela para servirem às necessidades do capital” (Braverman 1981, p.231).

Berta Ribeiro (1984:11) em estudo sobre a comercialização de artesanato indígena, distingue a produção "para dentro" como sendo o equipamento de ação sobre a natureza para o provimento da subsistência e a parafernália ritual, da produção "para fora", ou seja, a produção de um excedente para além das necessidades dos produtores diretos. Ela chama a atenção sobre o perigo da produção para o mercado causar um desequilíbrio social com a introdução de formas de exploração do homem pelo homem, para o fato de que a produção em massa descaracterizar a expressão estética , estilística e cultural do artesanato tradicional e para a troca desigual, isto é, produtos artesanais que demandam grande dispêndio de tempo e esforço em sua confecção pelos quais se pagam, muitas vezes, preços irrisórios (Ribeiro,1984:13).

Por outro lado, a autora faz algumas ressalvas, dizendo que, os produtos artesanais, pelo seu caráter, muitas vezes exótico, por ser um produto manufaturado de sabor primitivo e ingênuo é muito valorizado e cobiçado em mercado consumidores mais refinados. 
Segundo a autora, a produção de artesanato para o mercado não é um mal em si. Seu aspecto mais deletério é introduzir modificações na divisão tradicional do trabalho entre os sexos, mas que, todos os males são passíveis de correção.

No contato com o mercado, o artesão tende a modificar e adaptar seu produto afim de atender à demanda. Assim, pode lançar mão de materiais industrializados que considera interessantes, mas que, podem subtrair ao produto sua estética original, descaracterizando o produto (Ribeiro, 1984).

Ribeiro (1984) faz uma série de questionamentos sobre essa atividade e considera que tais observações são válidas para todo artesanato popular brasileiro. As questões levantadas pela autora são as seguintes:

$\checkmark$ Em que medida a produção artesanal para o comércio serve ao artesão tradicional como fonte de recursos para obtenção de bens industriais de que não mais pode prescindir?

$\checkmark$ Até que ponto essa atividade obsta sua saída de sua comunidade para empregar-se em outras atividades urbanas ou rurais?

$\checkmark$ A produção de artesanato interfere em suas atividades rotineiras de provimento da subsistência?

$\checkmark$ Em que proporção a atividade artesanal para o comércio constitui para o artesão tradicional, um trabalho dignificante que alimenta seu orgulho e reforça sua identidade étnica?

$\checkmark \quad O$ artesanato para a venda descaracteriza a concepção artística peculiar à cultura pela introdução de novos temas, novos modos de exprimir os motivos tradicionais, a utilização de materiais heteróclitos?

$\checkmark$ Quais as providências que devem ser tomadas para a conservação da atividade artesanal e para que ela seja transmitida às novas gerações, continuando a funcionar como um mecanismo através do qual o sujeito se identifica e é assim identificado pela sociedade envolvente?

Para responder a essas questões a autora lembra que: 
" cabe averiguar até que ponto a produção artesanal para fora pode alterar as principais instituições sociais que regem a vida indígena, bem como o ecossistema de que o indio participa, cuja destruição representa a destruição de seus modos de vida tradicionais e de sua própria existência como entidade étnica" (Ribeiro,1984:)

Com relação ao tipo de artesanato a ser produzido para o mercado, Ribeiro (1984) ressalta que não se deve comercializar objetos rituais, objetos produzidos a partir de matérias-primas escassas, e que não constituam a totalidade do acervo de cultura material que essa sociedade detém e produz para uso próprio.

Segundo a autora, outro tema de crucial importância diz respeito à preservação e ao aprendizado do artesanato, para os quais devem-se utilizar os melhores artesãos de cada comunidade, reconhecidos internamente como tais, para ensinarem sua arte às gerações mais novas.

Quanto à comercialização, Ribeiro (1984) tem um pressuposto básico: deve ser realizada diretamente pelos artesãos pois, com a intermediação, o lucro maior fica com o revendedor. Assim, a autora conclui que os cuidados a serem tomados por todos aqueles - sejam instituições governamentais ou não-governamentais - que estimulam ou trabalham com a produção de artesanato indígena (aqui são selecionados os ítens que cabem para o artesanato tradicional, não-indígena), são os seguintes:

Não adquirir artefatos em que se empregam matéria-prima escassa e exaurivel.

Considerar que a cultura material de um grupo serve à sua reprodução social e não deve ser tomada em sua totalidade, como um artesanato para a venda.

Evitar que a atividade artesanal para o comércio interfira nas instituições que regulam a vida social do grupo, como 
a divisão social do trabalho, o sistema de distribuição de bens e as atividades para o provimento da subsistência. Incentivar a transmissão de técnicas artesanais às novas gerações, através dos artesãos mais destros.

Estimular a produção mais elaborada.

Devolver informação aos grupos que mais necessitam através do envio de registros iconográficos e técnicos.

Ter em conta que a produção artesanal para fora objetiva a conservação do artesanato para dentro, como símbolo da identidade étnica, de autonomia cultural e econômica e de orgulho.

Considerar que o artesanato destina-se a um público seletivo, não pode transformar-se em produção em massa (Ribeiro, 1984: 26).

\subsection{A Cultura Caiçara}

\subsubsection{Caracterização}

Para entendimento da cultura caiçara fazem-se necessárias algumas considerações sobre o conceito de culturas ou sociedades tradicionais, dentro das quais a cultura caiçara se encaixa.

Segundo Diegues (1994), as culturas tradicionais caracterizam-se por um modo de vida com um tipo de organização econômica e social onde:

- há dependência e conhecimento aprofundado da natureza e seus ciclos naturais, passado de geração em geração através da tradição oral;

- noção do espaço ocupado pelo grupo, ao longo de gerações, como local de reprodução econômica e social ;

- importância de atividades de subsistência; reduzida acumulação de capital; 
- importância dada à vida familiar e doméstica e à relações de parentesco e compadrio;

- importâncias de simbologias, mitos e rituais associados à vida material;

- tecnologias simples e pequena divisão técnica e social do trabalho;

- fraco poder político;

- auto-identificação ou identificação pelos outros de se pertencer a uma cultura distinta das outras (Diegues, 1994).

A cultura caiçara está marcada por uma grande influência indígena, de quem os caiçaras incorporaram um patrimônio tecnológico, conhecimento do meio ambiente, de hábitos alimentares e da atividade agrícola, marcada pelo cultivo itinerante. Vários ítens da cultura material indígena foram incorporados ao modo de vida caiçara, entre eles, a canoa escavada em um tronco só, o tipiti (cesto flexível para espremer a massa da mandioca) e o uso de ervas medicinais (Mussolini, 1953).

Também se podem encontrar elementos da cultura portuguesa nas técnicas, na religiosidade, no folclore, e da cultura africana, principalmente na culinária e nas danças. A mistura das tradições européias, indígenas e, em menor parte, africanas, configuraram uma cultura rica e sincrética que permaneceu nas crenças, nas festas religiosas e profanas, nas estórias e lendas, costumes, alimentação, e muitos outros aspectos da vida social, cultural e política (Mussonini,1953).

Essa miscigenação dá ao caiçara, como em geral ao povo brasileiro, essa "mestiçagem na carne e no espírito", como salientou Darcy Ribeiro, através da mescla de diferentes aspectos genéticos e culturais (Ribeiro,1995).

Adams (2000) faz um apanhado de autores que definiram e caracterizaram a cultura caiçara. Assim, a autora cita Berta Ribeiro (1987) e Gioconda Mussolini (1953), que identificam a existência de um conjunto de subculturas, denominadas culturas rústicas brasileiras, nas quais se encontra a agricultura de coivara, o mutirão, o complexo cultural da farinha de mandioca, compadrio, novenas e folias, entre as quais está incluída a cultura caiçara. Segundo Adams (2000), outros autores ( Pierson \& Teixeira, 1947; 
Noffs, 1988; Silva, 1993) consideram a cultura caiçara como uma expressão regional da cultura caipira. A autora cita ainda França(1954) e Setti (1985) que consideram que, embora haja elementos comuns entre o caipira e o caiçara, este possui traços culturais definidos, tais como hábitos cuja origem remonta "ao colono português dos primeiros séculos de povoamento do país"(Adams, 2000: 105). Tais particularidades dessa região, segundo a autora, existem em função da deserção da população à medida que o povoamento avançou para o interior e a região ficou privada de influências culturais externas.

Diegues (1994) citando vários autores ( Foster, 1971; Redfield, 1971) enfatiza que as culturas tradicionais estão inseridas dentro de uma sociedade mais ampla, com as quais possuem importantes relações, das quais, em grande parte, dependem sua reprodução social, econômica e cultural.

Mussolini (1953) destaca que as populações caiçaras desenvolveram atividades de subsistência ao lado da grande lavoura monocultura de produtos voltados para a exportação. A produção, voltada para a subsistência, gerava um pequeno excedente, o que possibilitava a aquisição de bens que não eram produzidos, como o sal, querozene, tecidos e outros. Tais aspectos caracterizam o modo de vida caiçara como economia de pequena produção mercantil, com uso de técnicas de baixo impacto nos ecossistemas (Diegues, 1983) .

Nas sociedades caiçaras, a unidade básica de trabalho, de reprodução, de produção e consumo era a família nuclear ou extensa, com papéis sexuais bem definidos: a mulher trabalhava na casa e na roça e o homem na caça e pesca, derrubada e queimada da mata, serviços pesados da roça, construção, transporte e comercialização dos produtos agrícolas (Mussolini ,1953; França, 1954; Diegues, 1983, 1994; Adams,2000).

O território caiçara era composto pela terra e pelo mar, um referencial indivisível sobre o qual se assenta seu modo de vida, sua tradição cultural. Representava não apenas o local de onde tirava sua subsistência, seu trabalho, mas também de onde obtinha os meios de reproduzir os aspectos materiais de suas relações sociais, ou seja, 
suas relações de parentesco, religião, crenças, além da noção de territorialidade remeter à consciência étnica (França,1954; Diegues,1983, 1994).

Segundo Mussolini (1954), as escarpas montanhosa da Serra do Mar no Estado de São Paulo promoveram um isolamento das comunidades caiçaras que ali se estabeleceram, e que, devido ao baixo poder aquisitivo e baixa influência de fatores externos, resultou num

aproveitamento intensivo, quase exclusivo e mesmo abusivo dos recursos do meio, criando-se, por assim dizer, uma intimidade muito pronunciada entre o homem e seu habitat. Conhece o homem muito bem as propriedades das plantas ao seu redor - bem como os fenômenos naturais presos à terra e ao mar e que o norteiam no sistema de vida anfíbia que leva, dividindo suas atividades entre a pesca e a agricultura de pequeno vulto, com poucos excedentes para troca ou para a venda: os ventos, os "movimentos" das águas, os hábitos dos peixes, seu periodismo, a época e a lua adequadas para por abaixo uma árvore ou lançar à terra uma semente ou uma muda ou colher o que plantou ( 1954: 85).

A pesca artesanal, atividade essencialmente masculina, constituía-se como a principal atividade das comunidades caiçaras e determinava importantes aspectos das relações sociais e culturais. O pescado, juntamente com os produtos agrícolas - milho, mandioca, feijão - constituia-se como fonte básica da alimentação. A agricultura estava voltada para a subsistência e era praticada com o sistema de coivara e pousio Um dos produtos mais utilizados na alimentação do caiçara, cuja produção era fonte de grande mobilização era a farinha de mandioca. Sua produção envolvia, além de um complexo aviamento, que constituía no ralador, prensa, cocho e forno, o envolvimento de toda a família , ou mesmo da vizinhança (Mussolini, 1953, França, 1954, Diegues, 1983). 
Os caiçaras utilizavam a floresta para obtenção de recursos que lhes possibilitavam exercer suas atividades de pesca, agricultura, moradia, etc. Além da caça e coleta de alimentos, o caiçara retirava a madeira para as canoas, utensílios domésticos, aviamento para a produção de farinha, madeiramento para construção das casas de barro, e a lenha, além de fibras para cestaria, ervas medicinais e outros. Tanto a caça como a coleta eram praticadas com técnicas seletivas baseadas em seu conhecimento ancestral sobre os ciclos naturais (Mussolini, 1953; França, 1954; Diegues, 1983, 1994; Noffs, 1988; Luchiari, 1992; Cavente,1993).

Entre os caiçaras, predominava o catolicismo, com uma mistura de aspectos religiosos e profanos, que pode ser observado nas festas, nas crenças, nos mitos e no folclore (Diegues,1983). A vida social caracterizava-se por intensa solidariedade entre os grupos, posto que estava baseada nas relações de trabalho. A pesca era praticada de forma coletiva, envolvia cooperação, envolvimento espontâneo e divisão dos resultados (Mussolini,1953; França,1954, Diegues, 1983; Adams,2000). Os costumes e a moral estavam pautados pela austeridade, respeito à autoridade dos mais velhos, recato e pequena autonomia das mulheres e a grande importância do compadrio (França, 1954; Diegues, 1983; Marcílio,1986).

\subsubsection{Culturas Tradicionais frente às transformações}

Diegues(1994) salienta que as culturas tradicionais estão articuladas de forma diferenciada com a sociedade dominante e encontram-se transformadas em maior ou menor grau. Segundo o autor um dos processos desorganizativos reside na uniformização cultural produzida pelo capitalismo e pela sociedade de massas (Diegues, 1994).

Diegues (1994) ressalta que as sociedades tradicionais são dinâmicas e absorvem mudanças, sem, contudo, destruírem seu modo de vida baseado na pequena produção mercantil, dependendo do grau de relações estabelecida entre ambas. $\mathrm{O}$ autor cita Queiroz (1973), por seus estudos com sociedades camponesas, nos quais diz que, o 
primeiro sintoma da mudança surge na esfera do consumo pois o camponês passa a consumir mais frequentemente os produtos da cidade.

Diegues (1994) cita Cândido (1964) que, estudando caipiras do interior de São Paulo, assinala que um dos fatores principais de mudança na vida dos caipiras está no fato de "perderem" a terra, e passarem a viver do trabalho agrícola assalariado, a criando uma dependência maior do mercado urbano e perdendo as afinidades com o meio natural.

Calvente (1993), estudando as transformações trazidas pelo turismo no litoral norte de São Paulo, traz o histórico da ocupação da região à partir da década de 70, quando foram abertos os trechos da Rodovia Rio-Santos, como parte de um eixo rodoviário de ligação do Rio Grande do Sul ao Ceará. Segundo a autora o plano diretor para o litoral norte de São Paulo tinha a preocupação com os aspectos ambientais pois nesse local a serra se aproxima muito do mar, o que exigia diretrizes específicas. Porém, as obras foram realizadas em ritmo acelerado, ocasionando no aterro de praias, florestas, encostas e manguesais (Calvente,1993).

Siqueira(1989) citada por Calvente(1993:110), afirma que a partir daí iniciou-se "uma nova fase de devastação cujo agente principal é a especulação imobiliária...", que foi seguida por poderosos empreendimentos turísticos, privatização e poluição das praias que ancestralmente haviam pertencido aos caiçaras.

Segundo Afonso(1999), o turismo na região litorânea do estado de São Paulo, pode ser visto como o último ciclo de ocupação depois da mineração, indústrias, do gado, do açúcar e do café. A ocupação do litoral com a atividade turística está em função da viabilidade de acesso à região litorânea. As vias de acesso ao litoral eram restritas a precários caminhos que ligavam o planalto ao litoral, com exceção à ligação ao Porto de Santos, em1867. No litoral norte do estado, até o início desse século, predominavam as atividades de subsistência, principalmente em função do isolamento em que a região se encontrava. Com a intensificação do transporte rodoviário e a construção de estradas, o acesso ao litoral foi facilitado proporcionando a expansão da atividade turística em larga escala, processo que, até então, estava restrito à baixada santista beneficiada pelo acesso ferroviário (Afonso, 2000). 
Diegues e Nogara (1994) estudando a vida da população caiçara do Saco do Mamanguá, litoral sul fluminense, salientam que a entrada do turismo, a expansão urbana, promoveram mudanças nessas comunidades a partir da venda da terra e do abandono das atividades tradicionais. Esse processo transformou suas relações sociais, alterou relações de trabalho, valores, impôs um novo padrão no uso do espaço e dos recursos naturais, implicando na qualidade de vida dessas populações, que passaram a ter necessidades de produtos que já não produzem, com uma dependência cada vez maior do mercado e cada vez menor das atividades de subsistência (Diegues e Nogara, 1994).

Segundo Calvente (1993), o turismo transforma as condições de subsistência da população através da

"passagem de uma economia onde a maior parte das necessidades eram atendidas pela produção da própria comunidade para uma economia onde o salário deveria poder atender as necessidades básicas de consumo que antes não existiam" (Calvente, 1993, p.124).

Vesentini(1989) citado por Calvente(1993, p.122) considera que a mundialização do capitalismo significou a imposição a outros povos e regiões o imperativo de que o trabalho deve ser produtivo, voltado para a produção de mercadorias, dentro de uma lógica de acumulação capitalista. Daí a idéia de que o índio é preguiçoso, e também o caiçara, cujo termo tem, entre outros significados, o de malandro e vagabundo (Aurélio, 86).

Marques(1995), em seu estudo em comunidades litorâneas, aponta as transformações que a entrada das relações capitalistas provoca entre comunidades tradicionais, através das quais inicia-se o processo de privatização da natureza. Essas relações privam a população local do uso dos recursos naturais que sempre utilizou e que, a partir desse momento, muitas vezes, precisa comprar. 
Diegues(1993) analisa as consequências desastrosas para os ecossistemas a partir da expulsão dos caiçaras de suas terras e ressalta que a desorganização dessas comunidades e de sua cultura tradicional tem caminhado junto com a destruição de importantes ecossistemas naturais; acrescenta ainda que essas comunidades, que tradicionalmente exploraram essas áreas, agora vivem à margem delas. As novas demandas que surgiram entre as comunidades determinam um novo padrão de uso do espaço e dos recursos naturais, acarretando um impacto ambiental com consequências para o presente e o futuro dos ecossistemas e dessas populações.

Essas transformações levaram à superexploração de alguns recursos naturais como o palmito, a caixeta, entre outros, uma vez que encontram maior aceitação junto ao mercado, garantindo melhor forma de subsistência (Diegues,1993; Diegues e Nogara,1994).

Nos anos 80, foram criadas Unidades de Conservação com o objetivo de conservar as áreas naturais . Com essa legislação ambiental restritiva ao uso de recursos naturais da floresta, os caiçaras que ainda vivem de atividades tradicionais foram novamente prejudicados, muitos deles, abandonando suas atividades, como é o caso dos artesãos que usam produtos madeireiros e não madeireiros retirados da floresta.

Segundo Diegues (1994), a degradação dos ecossistemas litorâneos, a legislação de proteção ambiental e a nova caracterização fundiária afastaram o caiçara da floresta, dificultando, ou impedindo-o de utilizar os recursos florestais para alimentação, artesanato e outros.

\subsection{A Caixeta - Tabebuia cassinoides (Lam.) DC.}

A caixeta - Tabebuia cassinoides (Lam.) DC é uma espécie arbórea, da família Bignoniaceae, de pequeno a médio porte, podendo chegar a $20 \mathrm{~m}$ de altura e $70 \mathrm{~cm}$ de DAP (Diâmetro na Altura do Peito) em florestas maduras. A espécie ocorre exclusivamente na planície litorânea, de Pernambuco a Santa Catarina e ocorre 
geralmente em agrupamentos densos, chamados caixetais (Ziller, 1992 citado por Marquesini 1994).

A floresta de caixeta é popularmente conhecida como caixetal. O caixetal é uma área de várzea ou brejo onde a caixeta ocorre com alta densidade. Esse ecossistema é singular devido às suas características, como o alagamento frequente e variação da lâmina d'água presente, que dificultam a fixação e sobrevivência de outras espécies arbustivas e arbóreas, favorecendo a dominância da caixeta sobre o estrato arbóreo (Pinheiro e Armelin, 1996).

A madeira é leve e mole, não racha durante a secagem e aceita acabamento ( Lorenzi, 1992; Carvalho, 1994 citados por Marquesini, 1994). Devido às essas características é muito usada para fabricação de lápis, lápis fino, tamanco e artesanato em geral (Marquesini, 1994).

Popularmente, a caixeta é denominada caxeta (PR), caixeta (SP,ES), pautdetamanco (ES,PR), pau-paraíba e tamanqueira (ES), tamancão, malacaxeta (SP, PR), paut caxeta, pau-caixeta, pau-viola (PR) e outros (Nolasco, 2000).

A cobertura vegetal do Estado de São Paulo vem sendo progressivamente destruída. A planície litorânea no município de São Sebastião, originalmente possuía grandes áreas com ocorrência de caixeta, que vem se restringindo devido à ocupação urbana. Com a ocupação dessas áreas para a construção, muitos aterros recortaram os caixetais, extinguindo-os ou deixando apenas alguns fragmentos. Tais fragmentos, localizados em propriedades particulares, estão abandonados e sujeitos à perturbações e no entanto representam parte das florestas naturais, últimos depositários da biodiversidade natural de boa parte das florestas ( Viana et alii, 1992 citado por Armelin,1994).

Segundo Pinheiro e Armelin (1996), no levantamento de caixetais do município de São Sebastião, a área estimada era de 250 hectares de caixetais no município no ano de 1996.

Os caixetais de São Sebastião vêm sofrendo uma forte pressão resultante da expansão desordenada da área urbana. A especulação imobiliária e o aumento das construções determinam o aterro de diversas áreas (mangues, brejos, e várzeas) e a 
devastação de diversas formações vegetais (restingas, mangues e caixetais, entre outros), em detrimento desses ambientes e das populações locais que utilizam matéria-prima para suas manufaturas ( Pinheiro e Armelin, 1996).

Atualmente, os caixetais são propriedades privadas. Antes da chegada do turismo, essas áreas eram de uso comum. Geralmente pertenciam às áreas de posse das famílias locais. Com a especulação imobiliária essas áreas foram vendidas para empresas ou particulares, e vêm, ao longo do tempo, sendo aterradas pois encontram-se em localização apropriada para a construção de condomínios e residências Os caiçaras não utilizavam essas áreas para agricultura, mas somente como fonte de coleta de matérias-primas ou caça (São Sebastião/PCSSTA, 1997).

A exploração da caixeta no município de São Sebastião é praticada pelos artesãos e ocorre sem planejamento prévio ou acompanhamento. A ausência de um Plano de manejo normalmente resulta em práticas inadequadas de exploração, com a não execução de desbrota após o corte, que pode diminuir o incremento da madeira e comprometer ações futuras. Entretanto, dada a incidência de caixeta existente originalmente no município, o volume de madeira explorada e o intervalo entre as extrações, pode-se considerar que a exploração para o artesanato tem um impacto muito peque no em termos ambientais

( Pinheiro e Armelin, 1996).

A degradação dos caixetais do município estão em função da pressão da urbanização e do assoreamento de rios, lançamento de detritos sólidos em cursos d'água , criação de barragens, açúdes e estradas cruzando cursos d'água e alterando os regimes hidrológicos ( Pinheiro e Armelin, 1996).

O processo de urbanização fragmenta a floresta e o caixetal. Muitos fragmentos de caixetais do município de São Sebastião possuem esse histórico. Aos poucos, esses fragmentos são aterrados e destruídos. Entretanto existem caixetais em plenas condições para a conservação, beneficiando esses ecossistemas e as populações que dependem do uso de seus recursos. Para tanto deve-se basear essa conservação no manejo sustentável da caixeta ( Pinheiro e Armelin, 1996). 


\begin{tabular}{|c|c|c|}
\hline Bairro & Situação para Manejo & Área estimada \\
\hline Maresias & Ruim & 5 ha \\
\hline Maresias & Médio & 11.7 ha \\
\hline Maresias & Médio & 29.6 ha \\
\hline Maresias & Médio & 0.6 ha \\
\hline Maresias & Ruim & 34.8 ha \\
\hline Maresias & Ruim & 3 ha \\
\hline Maresias & Médio & 29.8 ha \\
\hline Maresias & Médio & 38.6 ha \\
\hline Camburí & Bom & 9 ha \\
\hline Camburí & Bom & 1.9 ha \\
\hline Camburí & Ruim & 0.4 ha \\
\hline Camburí & Médio & 2.2 ha \\
\hline Camburí & Ruim & 0.3 ha \\
\hline Pegorelli & Médio & 54 ha \\
\hline Pegorelli & Médio & 2.2 ha \\
\hline Pirassununga & Médio & 3.8 ha \\
\hline Guaecá & Ruim & 2.5 ha \\
\hline Guaecá & Ruim & $26.25 \mathrm{ha}$ \\
\hline Baleia & Ruim & 10.5 ha \\
\hline Baleia & Médio & $-*$ \\
\hline Baleia & Médio & -* \\
\hline Baleia & Médio & $-*$ \\
\hline Baleia & Médio & $-*$ \\
\hline Área Total & & 250 ha \\
\hline
\end{tabular}

Quadro 1 .Relação dos caixetais de São Sebastião em relação à situação de manejo e área estimada.

Fonte: Levantamento dos Caixetais do Município de São Sebastião/SP, realizado por Pinheiro e Armelin, 1996.

\section{Legenda}

Bom - áreas protegidas a curto prazo

Médio - caixetais próximos a áreas urbanas e/ou com alterações no regime hidrológico

Ruim - fragmentos aterrados/drenados ou com alagamento permanente

* - áreas que não foram calculadas

A região do Vale do Ribeira concentra a maior parte dos remanescentes de caixetais do Brasil, numa área estimada de 3.000 hectares. No litoral norte de São Paulo, 
nos municípios de São Sebastião e Ubatuba, e em Paraty, litoral sul do Rio de Janeiro devido à sua localização, próximas ao mar, os caixetais sofrem forte pressão da crescente urbanização das áreas de planície litorânea para construção de condomínios e loteamentos (Marquesini et all, 1996 citado por Nolasco, 2000). No norte do Estado do Paraná, também encontram-se áreas com caixetais nos municípios de Morretes, Guaraqueçaba, Paranaguá, Matinhos, Pontal do Paraná e Guaratuba ( Galvão et al., 1999 citado por Nolasco, 2000)

\begin{tabular}{|c|c|c|c|}
\hline Município/UF & $\mathrm{N}^{\mathbf{0}}$ de Caixetais & $\begin{array}{c}\text { Área estimada } \\
\text { (ha) }\end{array}$ & $\begin{array}{c}\text { Área em } \\
\text { U.C. (ha) }\end{array}$ \\
\hline Iguape/SP & 50 & 1170 & 445 \\
\hline Ilha Comprida/SP & 1 & 70 & 70 \\
\hline Pariquera-Açu/SP & 4 & 90 & O \\
\hline Paraty/RJ & 5 & 185 & 140 \\
\hline Sete Barras/SP & 4 & 185 & 0 \\
\hline Cananéia/SP & 3 & 135 & 65 \\
\hline Registro/SP & 2 & 45 & 0 \\
\hline São Sebastião/SP & 5 & 45 & 15 \\
\hline Ubatuba/SP & 1 & 15 & 785 \\
\hline Linhares/ES & 1 & 50 & 1990 \\
\hline Total = 10 & 76 & & 0 \\
\hline
\end{tabular}

Quadro 2 - Áreas de ocorrência de caixeta na região sudeste do Brasil Fonte: Marquesini, M.- III Relatório do Projeto "Manejo Integrado e Sustentável de Florestas de Caixeta no Vale do Ribeira, SP” (não publicado) citado por Nolasco (2000).

Desde a década de 40 a caixeta era usada de forma incipiente na produção de caixas finas, instrumentos, etc. Em 1950 a caixeta começou a ser usada para fabricação de lápis pela Faber Castel. (Ramos,1994 citado por Marquesini s/d). Nas décadas de 70 e 80 , o consumo de caixeta aumentou muito e muitas serrarias foram instaladas no Vale do 
Ribeira, tornando-se um importante recurso econômico para a população local (Diegues, 1991).

No município de Iguape, onde a exploração era intensa, a população envolvida com a produção e beneficiamento da caixeta passou a exigir das autoridades responsáveis uma legislação mais adequada, que atendesse a conservação da espécie e as necessidades sócio-econômicas da população (Marquesini,1999).

Devido à quase paralização da atividade de exploração de caixeta no período 9196, tornou-se difícil a reinserção da caixeta no mercado. Atualmente existe apenas a demanda de Silveiras, para o artesanato, que está por volta de 50 metros estere/mês.

\section{Legislação}

Um fator de grande impacto nas comunidades caiçaras foi a criação das Unidades de Conservação e a criação da legislação ambiental que protege as áreas naturais. A aplicação da legislação por parte dos órgãos governamentais impede que atividades tradicionais fundamentais para a sobrevivência das comunidades sejam realizadas uma vez que dependem da extração de madeira e outros recursos não madeireiros oriundos da floresta, gerando conflitos e favorecendo atividades predatórias ( Luchiari, 1992; Calvente, 1993; Diegues, 1993; Nolasco e Armelin,1997)

Até fins dos anos 80 a exploração da caixeta não tinha uma norma própria. Em 1989 foi instituído o Decreto federal $n^{\circ}$ 99.574/89 suspendendo toda atividade de corte de caixeta no Estado. As restrições atingiram as populações ligadas à extração e ao desdobro da caixeta do Vale do Ribeira, assim como os caiçaras de São Sebastião que usavam a caixeta para o artesanato (Diegues, 1991; Nolasco e Armelin, 1997).

A partir de 1991 a Secretaria de Meio Ambiente do Estado (SMA/SP) instituiu normas para elaboração de planos de manejo de caixeta para o Estado, culminando na Resolução SMA -11/92, que normatiza a exploração sob "regime de rendimento autosustentado". Posteriormente essa Resolução foi amparada pelo Decreto Federal do

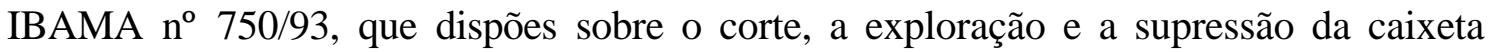
(Marquesini, 1994). 
Apesar do Decreto n 750/93 admitir a exploração da vegetação pelas populações tradicionais com a devida autorização do órgão competente, na prática o uso legal é inviabilizado devido à desinformação, à burocracia e aos custos de implantação de um plano de manejo. Como não há uma organização de usuários de caixeta que solicite e encaminhe esse plano, no município de São Sebastião só ocorre extração ilegal. Esse fato impede e desestimula os artesãos a continuarem a produzir artesanato (Nolasco e Armelin, 1997).

Atualmente, uma das perspectivas que se apresenta no mercado para produtos florestais é a certificação sócio-ambiental. A certificação foi um mecanismo criado pelo e para o mercado para avaliar e garantir a qualidade do manejo florestal, considerando a proteção aos ecossistemas, a qualidade do trabalho humano e apoio social à comunidade local, e a otimização econômica da atividade. (Viana et all, 1996).

O sistema de produção da caixeta apresenta boas condições para a certificação devido às características que ela apresenta, um vigor na rebrota e dominância no extrato arbóreo. O manejo da caixeta possui impactos ambientais muito inferiores às demais alternativas econômicas de aproveitamento da terra nas regiões de ocorrência da espécie, além de não utilizar nenhum tipo de agrotóxico. A madeira da caixeta é utilizada em produtos de alto valor agregado como lápis de alta qualidade, caixas de jóia, artesanato e outros e, por fim, o manejo da caixeta é realizado por populações locais que se beneficiam diretamente dessa atividade. Tais características criam condições muito favoráveis para a certificação da caixeta, diferenciando os produtos dentro do mercado(Viana et all, 1996).

Apesar desse potencial, a certificação sozinha não é capaz de viabilizar o bom manejo da caixeta. São necessários esforços conjuntos entre instituições governamentais e não governamentais, universidades, empresas, produtores e consumidores para se conseguir o bom manejo dessa espécie(Viana et all, 1996). 
Florestais da ESALQ/USP, que realizaram estudo de mapeamento do artesanato de São Sebastião/SP, produzido a partir de materiais oriundos da Mata Atlântica.

O PCSSTA atuou junto aos artesãos entre os anos de 1989 a 1997, ano em que estabeleceu uma parceria com o Projeto Artesãos da Mata Atlântica. Os primeiros trabalhos realizados com os artesãos, no início de 1989, foi no sentido de dar-lhes visibilidade pois realizavam seu trabalho em suas casas e a população local conhecia muito pouco esse trabalho. Com essa proposta foram realizadas feiras, exposições em praças públicas e, por fim, a instituição das Escolas de Artesanato, que levaram os artesãos para as salas de aula para ensinarem seu ofício.

Em 1997, com a parceria com o Projeto “Artesãos da Mata Atlântica” buscou-se dar um enfoque às questões relativas à matéria-prima do artesanato, isto é, a caixeta e demais fibras que eram utilizadas. Essa experiência confirmou o estado de fragilidade em que se encontrava a atividade no município, e a partir dela, foi elaborado o projeto para aprofundar o estudo sobre o tema.

O objetivo dessa dissertação consistiu inicialmente em estudar o sistema produtivo do artesanato de caixeta de São Sebastião/SP, especificamente no bairro de Camburí, onde se localiza o maior número de artesãos, realizando uma análise das condições gerais do sistema, visando identificar quais seus pontos críticos, o contexto em que se realiza e os elementos necessários para viabilizá-lo.

No início do ano de 1999, já em fase de levantamento de dados para essa dissertação, foi realizada uma viagem ao município, e verificou-se que a atividade, seguindo a tendência em que se encontrava, estava praticamente extinta. Nessa ocasião, foram encontrados 4 artesãos que ainda produziam. Eram os mais estrut urados, os que tinham uma loja para comercialização de artesanato de diferentes origens, vivendo mais dessa atividade do que da produção de artesanato.

Percebeu-se que a presença maciça do artesanato de Silveiras/SP, similar ao produzido em São Sebastião, no local, era um fator que se somava aos demais no processo de desestruturação da atividade, visto que alguns artesãos locais deixaram de produzir seu artesanato para revender os produtos de Silveiras. Percebeu-se também que 
o sistema de produção de Silveiras estava bastante aprimorado, principalmente em relação à comercialização, pois o produto dominava o mercado local e nacional.

Os artesãos locais queixavam-se dos produtos de Silveiras pela concorrência que tais produtos faziam com o artesanato local, por introduzirem padrões de pintura que ganhavam a preferência do turista e por serem vendidos a um preço mais baixo, fazendo forte concorrência com o artesanato local. Assim, a produção de Silveiras passou a fazer parte do escopo dessa pesquisa pois sua existência indicava que a produção de artesanato estava adquirindo uma nova forma dentro e a partir de suas relações com o mercado. Esse fato proporcionaria uma discussão, no âmbito dessa pesquisa, abordando as relações com o mercado e suas interferências na produção local. Optou-se, então, pela inserção do estudo do sistema de produção de Silveiras visando conhecer sua estruturação, servindo de base para uma análise comparativa entre os dois sistemas de produção.

Assim definiu-se pelo levantamento de dados sobre a produção de artesanato de caixeta no município de São Sebastião/SP e produção de artesanato de caixeta no município de Silveiras/SP. Os dados foram levantados em diferentes momentos para cada um dos dois locais de estudo ( Quadro 3). Os dados de São Sebastião referem-se a uma situação ocorrida ao longo de uma história local e seu desfecho nos últimos10 anos. O objetivo desse levantamento é fazer, prioritariamente, uma abordagem histórica e qualitativa. Os dados de Silveiras são referentes ao ano de 1999 e possuem uma abordagem qualitativa.

A partir da análise das informações sobre esses dois sistemas de produção identificaram-se os fatores de sustentabilidade do sistema de produção de São Sebastião. 


\begin{tabular}{|c|c|c|c|c|c|}
\hline Ano & $1989-1997$ & 1990 & 1997 & 1999 & 2000 \\
\hline São Sebastião & $38^{*}$ & $96^{* *}$ & $27^{*}$ & 6 & 11 \\
\hline Silveiras & & & & 23 & \\
\hline
\end{tabular}

Quadro 3 - Número de entrevistados em cada município e ano do levantamento

* Artesãos que trabalhavam com diferentes matérias-primas

** Listagem de artesãos obtida na prefeitura

\section{$1^{\circ}$ levantamento de dados em São Sebastião}

Sobre o artesanato em São Sebastião, foram reunidos dados levantados ao longo do trabalho com o PCSSTA, em diferentes momentos. Durante esses anos de trabalho, foram realizados levantamentos de dados relativos ao conjunto das manifestações culturais da população local. Esses dados dizem respeito aos aspectos tradicionais das atividades de pesca, agricultura, extrativismo, produção de utensílios, festas, religião, costumes, entre outros. Tais dados foram levantados através de atividades como festas, fóruns de debates, visitas informais, entrevistas e muitas outras formas de convivência. Essas formas de convivência com a comunidade eram muito variadas, envolvendo atendimento de vários níveis à população, tais como reestruturação de escolas, implantação de rádio de comunicação, distribuição de alimento e roupas, realização de festas típicas, cursos, intermediação junto aos órgãos públicos para resolução de diferentes questões, e outras.

De um total de 100 entrevistas realizadas pelo PCSSTA foram escolhidas 38, que tratavam especificamente das questões relativas ao uso dos recursos florestais para a produção de objetos de uso dos caiçaras.

Tais entrevistas foram realizadas durante os anos de 1989 a 1997; são entrevistas abertas e semi-estruturadas. Também foram consideradas nesse estudo as resoluções de cada fórum de debates realizados pelo PCSSTA onde se reuniram representantes de comunidades tradicionais ligados à pesca, a agricultura, extrativismo e artesanato, autoridades, técnicos e universidade para a discussão das questões pertinentes a cada área. Cada um dos 6 fóruns realizados durante a década de 90 resultou numa carta que 
apresenta os principais problemas de cada atividade e as propostas dos participantes. Esse conjunto de dados obtidos através do PCSSTA foram o ponto de partida para o levantamento dos demais dados.

\section{$2^{\circ}$ levantamento de dados em São Sebastião}

Em 1997, foi realizado outro levantamento do artesanato e diagnóstico sócioeconômico dos artesãos em parceria do PCSSTA com o Laboratório de Movelaria e Resíduos Florestais do Departamento de Ciências Florestais da ESALQ para o Projeto Artesãos da Mata Atlântica, sob a coordenação da Prof ${ }^{a}$ Adriana Nolasco. Na ocasião, foi obtido junto à prefeitura local uma lista de artesãos cadastrados em 1990, único registro referente à atividade disponível no município. Trata-se de uma lista onde estão os nomes dos artesãos, a matéria-prima utilizada e o tipo de produto. A partir dessa lista buscou-se o contato com os artesãos.

Esses dados foram levantados através de questionários, buscando conhecer o artesão e entender o sistema de produção de artesanato através dos seguintes aspectos: (i) origem; (ii) sexo; (iii) idade; (iv) escolaridade; (v) renda, (vi) matéria-prima utilizada; (vii) produtos, (viii) origem da matéria-prima, (ix) forma de acesso à matériaprima, (x) comercialização. Nessa ocasião, foram entrevistados artesãos que utilizam diferentes produtos florestais.

Para levantamento desses dados, foi realizado um censo partindo-se da lista obtida junto à prefeitura em 1990. Muitos artesãos não foram encontrados ou tinham deixado a atividade por diferentes motivos, principalmente pelo desestímulo em relação à própria atividade. A partir dos artesãos contatados formoutse uma rede de informações que levaram a outros artesãos que não constavam da lista de 1990.

Esses artesãos foram selecionados em função dos seguintes critérios: (i) estarem produzindo artesanato, uma vez que muitos daqueles 90 artesãos da lista de 1990 já não produziam mais, (ii) serem encontrados, pois alguns já haviam falecido ou mudado de cidade. 
Foram realizadas visitas aos artesãos locais ao longo do ano de 1997 em que foram entrevistados 27 artesãos, usuários de caixeta, taboa, taquara e outros materiais. Desses, 11 trabalhavam com a caixeta e apenas esses foram considerados nesse estudo.

\section{$3^{0}$ levantamento de dados em São Sebastião}

No início de 1999, foi realizada nova coleta de dados para atualização das informações, seguindo a lista de artesãos de 1997. Na ocasião, já estava definido o universo de trabalho com o artesanato de caixeta. Foram encontrados apenas 4 artesãos trabalhando com caixeta e foram realizadas entrevistas estruturadas, semi-estruturadas e conversa informal. Foram levantados os seguintes dados: (i) renda, (ii) forma de coleta da caixeta, (iii) dificuldades encontradas para a coleta da caixeta, (iv)locais de comercialização. Foram entrevistados 2 ex-artesãos.

\section{$4^{0}$ levantamento de dados em São Sebastião}

Em março de 2000, foi feito novo levantamento de dados, seguindo as características do levantamento de 1999, visando acompanhar as alterações da produção. Os artesãos foram contatados a partir das listas anteriores. Foram realizadas

entrevistas estruturadas e semi-estruturadas e conversa informal. Foram levantados os seguintes dados: (i) renda, (ii) forma de coleta da caixeta, (iii) dificuldades encontradas para a coleta da caixeta, (iv)locais de comercialização, com realização de entrevistas semi-estruturadas. Nessa ocasião identificou-se um aumento do número de artesãos a partir de um novo aquecimento da atividade. No último levantamento apenas 4 artesãos tinham sido encontrados e nesse momento foram encontrados 11 artesãos.

\section{$1^{\circ}$ levantamento de dados em Silveiras}

O primeiro contato com os artesãos de Silveiras iniciou-se a partir da indicação dos artesãos de São Sebastião. A referência para o artesanato em Silveiras é o artesão João Camilo, o mais antigo artesão do município. A primeira viagem a Silveiras ocorreu em 1998, ocasião em que foi realizada uma entrevista aberta com o Sr. João Camilo, através da qual levantaram-se as informações preliminares sobre a produção local. Ainda 
nessa ocasião foi realizada uma visita informal a uma unidade de produção (moradores e artesãos locais chamam a estas unidades de fábrica).

Através da entrevista com João Camilo levantaram-se dados sobre o (i) número estimado de unidades de produção do município; (ii) principais unidades de produção; (iii) nome dos proprietários; (iv) localização dessas unidades.

\section{$2^{\circ}$ levantamento de dados em Silveiras}

A segunda viagem a Silveiras foi realizada em 1999 e foi programada a partir das informações obtidas na viagem anterior. Foram visitadas 11 unidades de produção, de um universo estimado de 18 a 20 unidades. Os critérios de escolha dessas unidades foram (i) o tamanho da unidade; (ii) a disponibilidade do proprietário/artesão em ser entrevistado. Procurourse abarcar através do critério do tamanho da unidade, as grandes e as pequenas unidades, grandezas essas definidas por João Camilo, de acordo com o número de funcionários envolvidos. Foram aplicados 11 questionários (modelo anexo) para os proprietários das mesmas para o levantamento dos seguintes dados (i) nome e idade do proprietário; (ii) tempo de existência do empreendimento; (iii) tipo de empresa (Micro-empresa, CNPJ, etc); (iv) faturamento bruto; (v) custo operacional; (vi) número total de empregados; (vii) número de empregados registrados; (viii) número de empregados terceirizados; (ix) melhor período de vendas; (x) locais de venda; (xi) comprador predominante; (xii) madeiras utilizadas/volume consumido cada madeira; (xiii) origem da caixeta; (xiv) uso de máquinas.

Foram também realizadas 12 entrevistas semi-estruturadas com artesãos que prestam serviço para as unidades de produção, isto é, artesãos que fazem entalhe, lixam ou pintam em suas casas, não têm vínculo empregatício com os proprietários das unidades de produção. Os entrevistados foram escolhidos pelas diferentes etapas de produção que realizam: entalhe, lixa, pintura e fornecimento de material (raiz, palitos de taquara). Os dados levantados referem-se a: (i) quantidade de peças produzidas por dia;

(ii) valor pago por peça; (iii) renda mensal; (iv) horas trabalhadas por dia; (v) recebe ajuda de familiares; (vi) relação de trabalho com o proprietário 


\subsection{São Sebastião/SP - Caracterização do município}

\subsubsection{Aspectos físicos e localização}

O município de São Sebastião localiza-se no litoral norte do Estado de São Paulo, sob as coordenadas geográficas $23^{\circ} 46^{\prime} \mathrm{S}$ e $45^{\circ} 25^{\prime} \mathrm{W}$. Possui $479 \mathrm{Km}^{2}$ e uma população de 33.430 habitantes (Seade, 1991). A região é tropical úmida, com período seco anual variando entre zero e sessenta dias, segundo o Projeto RADANBRASIL de 1993. A classificação de Köppen encaixa São Sebastião no tipo climático Cfa, não havendo inverno seco e com a temperatura do mês mais frio, julho, inferior a $18^{\circ} \mathrm{C}$, e temperatura do mês mais quente, fevereiro, superior a $22^{\circ} \mathrm{C}$. Junto com os municípios de Ubatuba, Caraguatatuba e Ilhabela, formam o litoral norte de São Paulo (São Sebastião/PCSSTA, 1997) ${ }^{1}$

\subsubsection{Histórico do município de São Sebastião}

A região litorânea brasileira que abarca o litoral sul fluminense, toda a costa paulista e o litoral norte do Paraná é o território onde se desenvolveu a cultura caiçara. Ela está assim demarcada devido às características culturais e o modo de vida comum às populações que se encontram nessa região (Diegues, 1988).

O município de São Sebastião localiza-se no litoral norte paulista. Essa parcela do litoral é uma região, cujo processo de povoamento e colonização iniciou-se no período colonial, caracterizando-se pela ocupação de um espaço que já era habitado e visando suprir a demanda de gêneros tropicais e matérias-primas dos países europeus (Mussolini,1953).

A área urbana do município de São Sebastião localiza-se em uma pequena baixada litorânea entre a escarpa da Serra do Mar e o Oceano Atlântico, cujo povoado formou-se no início do século XVI, quando foram concedidas as primeiras sesmarias. Os

\footnotetext{
${ }^{1}$ PROJETO CULTURAL SÃO SEBASTIÃO TEM ALMA. Núcleo de educação, cultura e pesquisa dos povos do mar. São Sebastião, 1997, 132p. (Relatório de pesquisa).
} 
primeiros cultivos que formaram a base da economia local foram o fumo, o anil e a cana-de-açucar, a partir da qual estabeleceram- se engenhos de açúcar e aguardente.

A região toda possuía muitos engenhos tendo como motor a mão-de-obra escrava, também usada na agricultura. As riquezas da região atraíam navios mercantes além de corsários holandeses, franceses, espanhóis e ingleses (França, 1954).

Em 1636 o povoado foi elevado à categoria de vila e ainda nesse século foram edificados o Convento Franciscano de Nossa Senhora do Amparo, em 1659 e a Capela de Nossa Senhora na Fazenda do Guaecá, da ordem carmelita, em 1680, impulsionando a ocupação das costas norte e sul do município (França,1954).

O sítio portuário de São Sebastião, de condições naturais favoráveis, possibilitou o movimento de embarcações desde o início da colonização, contribuindo muito para o desenvolvimento local. Com o ciclo do ouro, no século XVII, aumentaram o movimento e a importância do Porto, mas diminuíram drasticamente no século XVIII, com a abertura de novos caminhos que ligavam a área de mineração ao Rio de Janeiro e desviando o movimento de exportações para outros portos da capitania. Nesse período desenvolveutse a pesca de baleia, atividade que permaneceu por mais de cem anos. No fim do século XVIII e começo do XIX, após reconquistar sua liberdade de comércio, o município viveu um momento de grande prosperidade (França,1954).

As atividades agrícolas ganharam novo impulso com a cultura de cereais, fumo e cana-de-açucar. Os engenhos se multiplicaram, desenvolveu-se o cultivo da banana junto à lavoura de subsistência. Em meados do século XIX iniciou-se o ciclo cafeeiro, com abertura de caminho que ligavam o litoral ao planalto. Desse período de riqueza permanecem os sobrados e casarões construídos no centro da cidade e nas fazendas.

O comércio entre as cidades litorâneas e o planalto era muito intenso, feito por tropas de animais em caminhos muito precários. Entre 1867 e 1877 foram construídas as ferrovias que ligavam São Paulo a Santos e ao Rio de Janeiro, desviando a exportação de café e outros produtos do Porto de São Sebastião para outros portos, abalando a economia litorânea, contribuindo para um novo período de isolamento e declínio econômico (França,1954). 
No início do século XX, outras regiões do Estado viviam um momento de urbanização e transformações com a chegada dos imigrantes. O litoral norte, entretanto, permaneceu em um relativo isolamento, economicamente estagnado.

Em meados desse século o litoral norte foi "redescoberto". Nos anos 50 foi construído o atual Porto comercial de São Sebastião, e em 1969 foi inaugurado o terminal marítimo da Petrobrás. Esse período coincidiu com a abertura, e melhoria das estradas de acesso ao litoral desencadeando um movimento turístico que deu início a uma nova ocupação. O turismo de veraneio impulsionou a venda da terra pelos caiçaras locais, que, alheios ao mercado, venderam suas posses por preços irrisórios. Nos anos 60 iniciou-se o turismo de massa. Proliferaram os campings, desenvolveram-se os ramos de hotelaria, gastronomia, turismo náutico, serviços, etc. (Diegues,1988, 1994; São Sebastião/PCSSTA,1997).

O processo de ocupação nas décadas de 50, 60 e 70, ocasionou um impacto muito grande na cultura local. A comunidade caiçara de São Sebastião sofreu profundas e rápidas transformações a partir da abertura da rodovia Prestes Maia (SP-55) na década de 60. A perda da terra e do acesso ao mar levou o caiçara para os sertões, como são denominados os espaços junto à mata, ou para a periferia da cidade. Esse fato implicou no abandono da pesca, da agricultura e do extrativismo, de onde tirava seu sustento para uma busca pelo emprego na cidade, passando a viver principalmente de serviços ligados ao turismo, e em pequena escala, daquelas atividades tradicionais (Luchiari,1992).

As novas gerações, seduzidas pelos encantos trazidos pelo turismo, não encontram razão de ser na cultura original, mas também não se inserem nos padrões atuais do consumo, da moradia e ficam marginalizados tanto das atividades econômicas como das sociais (Diegues,1993; São Sebastião/PCSSTA,1997) 


\subsection{Silveiras/SP - Caracterização da região}

\subsubsection{Aspectos físicos e localização}

Silveiras está localizada na região chamada Fundo do Vale ( Vale do Paraíba), sob as coordenadas 22.40 S e 44.52W. Tem como limites as cidades de Areias, Cunha, Lorena, Cachoeira Paulista, Cruzeiro, Lavrinhas e Queluz.

Encontra-se entre duas grandes serras: Serra do Mar e Serra da Mantiqueira, na

área de "garupas" caracterizada pelos mares de morros. É cortada pelo ribeirão Silveiras, pelos rios Itagaçaba, Bocaina e outros.(Boletim n ${ }^{\text {o }} 10$ jan/mar 1979 - Setor de Pesquisa e Documentação das Faculdades Integradas Teresa D’Ávila - Lorena)

Silveiras é um município com $412 \mathrm{~km}^{2}$. Possui $670 \mathrm{~m}$ de altitude, clima temperado, inverno seco, temperatura entre 14 e $29^{\circ} \mathrm{C}$.

A população foi registrada ao longo dos anos com os seguintes números:

1841 - 5.200 habitantes, 1870 - 6.071, 1872 - 11.973,1886 - 24.950, 1945 - 6.754, 1970 - 5.452.( Boletim $n^{\circ}$ 10/79). Segundo dados do IBGE, em 1996 o município possuía 5.240 habitantes. Note-se a queda do número de habitantes, relacionada à perda das atividades econômicas tradicionais.

\subsubsection{Histórico do município de Silveiras}

A origem do município deu-se com a vinda e fixação de famílias que vieram da região de Taubaté com sentido para o litoral, recebendo terras e abrindo estradas, sempre em busca de ouro( Ferraz, 1984)

As primeiras trilhas da região foram feitas pelos índios, que foram seguidas pelos desbravadores e aventureiros, nos muitos caminhos que levavam às cidades litorâneas de São Sebastião, Paraty e Mambucaba, em busca do mar.

Da necessidade de uma ligação por terra entre São Paulo e Rio de Janeiro como alternativa ao Caminho Velho do Embaú, cujo rumo era Guará, Cunha e Paraty, surgiu o Caminho Novo da Piedade em 1725. O Caminho Novo servia para o escoamento do ouro sem passar pelo mar, evitando-se a investida de corsários (Ferraz, 1984). 
O governo imperial doava sesmarias a quem quisesse construir o caminho e se fixar no local. Vieram famílias de vários locais: Guaratinguetá, Cunha, Taubaté, Pindamonhangaba. Segundo a história, Maria Mota ergueu o rancho mais importante na estrada, ponto de parada de tropeiros, e que daria origem à Silveiras. O rancho era o lugar de pouso do desbravador. Depois virou ponto de pouso, compra, barganha, abastecimento e prestação de serviços para os tropeiros. Nos ranchos dormia-se em rede, o fogão era de taipa, a construção rústica. Junto ao rancho fixava-se o ferrador, o seleiro, o armazém de secos e molhados (Ferraz, 1984).

Os tropeiros tiveram muita importância na ampliação das fronteiras nacionais, desde o início do século XVII e deixaram sua marca na história do município de Silveiras. Sua importância constitui-se pelo transporte de gêneros, informações, cartas, produção, divulgando costumes. Os tropeiros deixaram sua marca, integrando a cultura e fortalecendo a identidade do país, através da culinária, medicina caseira, benzimento e crendices, danças e músicas, anedotário e ditados, artistas populares, habitação e vestuário, linguajar, lendas e folguedos, artesanato folclórico e utilitário, divulgados pelo tropeiro(Ferraz, 1984).

Em meados do século XVIII o peso econômico do tropeirismo era absoluto, possibilitando a entrada em Minas Gerais, transportando o ouro. De Sorocaba, centro comercial de tropas no Brasil, partiam as tropas para todo o país. Esse comércio de tropas e os pousos que se formavam ao longo dos caminhos geravam atividades correlatas como seleiros, ferreiros, funileiros que se estabeleciam ao redor dos ranchos espalhados pelo território, ampliando e consolidando as relações comerciais.

Em 1730 já havia o povoado de Silveiras, cujo primeiro nome foi Capela das Pitas, em louvor a Nossa Senhora da Conceição, ao redor da qual foram se agrupando as primeiras casas. O caminho foi melhorando devido ao seu uso pelos tropeiros, o que fez com que alcançasse a importância de constar nos mapas Oficiais. Já Em 1800 o povoado era considerado bairro devido à afluência de pequenos sitiantes, fazendo parte do distrito de Lorena. Com a passagem de Dom Pedro pelo local, finalmente o povoado ganhou um novo status(Ferraz, 1984). Em 1830 é elevada à categoria de freguesia e recebe o nome 
oficial de Silveiras. Depois dos primeiros serviços foi construída a capela, che garam os missionários, as primeiras autoridades, um rancho para diversão.

O município sofreu com a Revolução Liberal de 1842. No âmbito da política nacional, os liberais estavam descontentes com os conservadores devido à elaboração de leis opressoras visando exercer maior controle das regiões. $\mathrm{Na}$ região toda, Guaratinguetá, Lorena, Areias, Bananal, os liberais estavam dispostos a lutar contra as leis conservadoras. Silveiras, sob o comando do tenente Anacleto Ferreira Pinto, tornour se o último núcleo de resistência da revolução. Os soldados de Caxias, que vieram para debelar a resistência, venceram a batalha, à qual se seguiram saques, destruição e fogo(Ferraz, 1984).

A sociedade de Silveiras se reergueu e nesse mesmo ano de 1842 foi elevada à categoria de Vila, sede de município, desmembrando-se de Lorena, título que perdeu como punição pela sua participação na revolução e só foi restituído em 1844, com a anistia. De acordo com o Censo Geral do Império de 1872, havia 11.973 habitantes na Vila (Ferraz,1984).

A cidade cresceu e caiu com o café. Toda a região era repleta de fazendeiros endinheirados pelo ciclo do café. No apogeu do café havia muita riqueza na região. A partir de 1880 começou o êxodo rural para o oeste do estado devido ao desenvolvimento dessa cultura nas terras férteis do interior. Em 1872 começou a ser construída a Estrada de Ferro Central do Brasil que passou distante do município de Silveiras. Tais fatores somados à abolição da escravidão, ao cansaço das terras, a política local mal conduzida e posteriormente, a industrialização das cidades vizinhas acarretaram a decadência econômica da cidade(Ferraz,1984). .

O Vale do Paraíba foi atingido economicamente com a crise do café, tendo esvaziado a economia dos pequenos municípios. As revoluções de 30 e 32 trouxeram mais danos à emergente pecuária leiteira. Em 1933 foi criada a Cooperativa Central de Laticínios do Estado de São Paulo, por iniciativa de líderes políticos da região de Pindamonhangaba, Guaratinguetá, Roseira, São José do Barreiro, Cruzeiro, Areias, fortalecendo a pecuária local. Com o fim do café o município voltou-se para o cultivo de produtos para subsistência e para a pecuária leiteira. (Ferraz, 1984). 
Em 1978, em pesquisa realizada no município encontrava-se artesanato feito com couro, crochê, doces, flores de palha, marcenaria, sisal, taquara, abrolhos (amarração de fios desfiados de tecido), tricô e pintura a óleo. Durante a década de 80 foram feitos esforços ( feiras, divulgação, Festa do Tropeiro, incentivo ao turismo) para incrementar a produção de artesanato, que já se direcionava para a confecção de objetos de madeira (Ferraz, 1984). 


\section{RESULTADOS}

\subsection{SÃO SEBASTIÃO}

\subsubsection{A cultura material dos caiçaras de São Sebastião}

$\mathrm{O}$ artesanato faz parte da cultura material da população caiçara e tem sua origem nas necessidades dessa população que retirava matéria-prima de seu local de moradia e transformava em bens de consumo e instrumentos de trabalho. Embora não fosse assim denominado, o que se chama aqui de artesanato popular tem essa origem na produção de objetos utilitários.

Todas as atividades cotidianas, a lavoura, a pesca, e as necessidades da casa e da família dependiam de um grande número de instrumentos, ferramentas, móveis e apetrechos diferenciados, para serem realizadas. A necessidade de produzir tais objetos desenvolveu habilidades para trabalhos com diferentes materiais, as técnicas para produzir os objetos, as diferentes espécies da floresta e o conhecimento dos ciclos naturais, do tempo apropriado para o corte e a finalidade de uso de um produto. Essas habilidades e conhecimentos foram passadas de pai para filho durante muitos anos, enquanto o modo de vida dos caiçaras ainda não havia sofrido as transformações por que passou, envolvendo sua cultura material, suas crenças e, principalmente, o acesso livre à terra e aos recursos naturais.

Sobre a construção das casas, diz dona Maria Aparecida:

“A casa, antigamente, não tinha esse negócio de fazer de tijolo, de bloco, porque naquela época não tinha essas 
coisas. Então era assim, cortava aquele monte de bambú, lascava o meio e pegava o tipo de um cipó de nome imbé, pegava os bambús e botava tudo assim nas paredes, amarrava com o cipó imbé, e, depois de toda casa pronta com esse trabalho, tinha que tirar um fim de semana com uma quantidade de pessoa pra fazer a barreada, que falava”.(Entrevista realizada com dona Maria Aparecida de Souza no ano de 1990).

O material era obtido no próprio local usando-se madeiras apropriadas para cada função:

"As casas eram de pau-a-pique e telha de barro antiga, casa de esteio de madeira, com uma sapata no pé de 60 centímetros, tudo enquadradinho, lavrado no machado. Usava canela preta pra terra, é uma madeira boa. Cedro pra fazer os esteios, tudo na altura. Cortava o pau roliço, pegava a viga e fazia caibro também (... ) o piso da casa era chão batido. Porta, janela, era tudo madeira aparelhada no enchó e serrado no traçado (...). A plaina era feita de madeira, madeira reta e plana. Meu pai fazia até porta, tudo feito à mão. E se, por exemplo, a gente precisava de uma dobradiça, de um prego, dobradiça era de couro, prego era pino de madeira” ( Entrevista com o artesão José Carlos dos Santos, no ano de 1992).

Um dos principais instrumentos de trabalho era a canoa, usada para a pesca e transporte. O senhor José Carlos, aprendeu a fazer canoa com seu pai, da escolha da madeira na mata ao feitio:

“Quando eu ia fazer uma canoa, já dizia, essa aqui é um Jequitibá, sabia pela cor, pela casca. Ou isso aqui é uma 
Canela, tudo tem sua utilidade né! Pra cortar uma madeira tem que entrar pra dentro da mata. A gente chega lá e escolhe a madeira. Tem muita madeira, de todo tipo. Então, quando é uma canoa pra viagem tem que ser uma madeira mais firme, madeira grande, que tem o diâmetro bem grosso. Jequitibá. Imbuia já é muito difícil dar uma canoa desse tamanho. O Cedro já dá uma canoa pra sair. Cedro, Jequitibá, Mirinduba e, justamente, temo também o Imbirussú. Como o Imbirussú era muito grande, então o pessoal fazia, mas era muito fraco, por pouco tempo, madeira que apodrecia muito fácil. Uma canoa pra viagem tem que ser de uma madeira mais grossa, canoa maior, né! Pra pesca, porque a distância é mais perto, então uma canoa de 3 a 4 metros e meio. Agora pra viagem era de 9 metros em diante"

( Entrevista com o artesão José Carlos dos Santos em 1992)

Para a casa e para o trabalho havia também uma grande necessidade de objetos produzidos pelos próprios caiçaras:

“ Meu pai fazia remo, fazia cabo de machado, tudo coisa que precisava pra casa, fazia as gamelas pra tomar banho, que antigamente não tinha chuveiro. As gamelas que a gente usava eram feita de figueira, raiz de figueira” ( Entrevista com o artesão José Carlos dos Santos em 1992)

Um equipamento muito importante para os caiçara era o aviamento para a casa de farinha, também chamado de tráfico da farinha. Consistia em uma roda para ralar a mandioca, prensa, cocho e forno. O feitio da farinha mobilizava a família e a vizinhança: 
"A gente arrancava a mandioca, demorava, é questão de 2 dias só pra arrancar, a gente trazia pra cá, raspava, né, bastante gente, sentava todo mundo ali junto, ajudava a raspar. Depois de raspadinha tinha que lavar, levá na roda, depois de raladinha, você derramava no cesto, chamado tipiti, colocava na prensa, né, pra apertar, escorre todo aquele caldo, chega até o ponto de enxugar, passa na peneira e larga no forno pra começar a fazê a farinha”

( Entrevista com dona Maria Cristina de Lara em 1992)

Fazia-se ainda o monjolo, tamanco, usado por homens e mulheres, a viola e a rabeca:

“Manjolo é uma peça que tem um pilão na ponta, e ele é justamente uma gamela, uma madeira lavrada de cinco metros de comprimento, então lá na ponta tem uma mão de pilão e aqui no meio é arriado com um eixo de madeira. Justamente aquela gamela enchia de água, levava ele lá e quando jogava a água fora batia o pilão”

( Entrevista com o artesão José Carlos dos Santos em 1992)

"Eu faço violino, é uma arte muito difícil. Pra fazer um violino a gente usa Pinho do Brasil. Viola a gente faz, só que não é uma peça só, é colado o tampo, a parte de cima e a parte de baixo é feita de uma madeira só"

( Entrevista com o artesão José Carlos dos Santos em 1992) 
Além da madeira usavam-se outros recursos não madeireiros da floresta para o feitio de cordas, cestos de vários formatos e tamanhos.

"Cesto feito de taquara durava muito. O pessoal de bordo de barco chegavam de pesca, eles encomendavam pra serviço no barco. Era muito fabricado em Camburí e Boiçucanga. Papai fazia pra nosso uso (...), fazia vassoura de cipó, peneira de camarão, pra pegá camarão no rio, pra abaná feijão"

(Entrevista com dona Maria Aparecida de Souza em 1990)

“Eu cortei palha pra mulher fazer abano. Palha de coqueiro do mato. Chama o côco preto, ele dá um cacho desse tamanho assim, é bom pra comer (...) É a brejaúva. Cortava o broto com o tempo bom. Só podia cortar com o tempo bom. Com o sol que nem agora, com 3 dias de sol já tava boa. Cortava na mata, trazia, botava no sol, deixava secar, depois dava a limpeza, tirava aquele cerro que tem pra fazer o abano”

(Entrevista com o senhor Aprígio Vicente em Barequeçaba, no ano de1997).

Para a corda, usava-se a casca da Embaúba, conhecida como embira e também a Pita, cuja fibra era tratada para se tirar o limo e depois fazer a corda:

"Fazia corda com imbira do mato. Eles tiravam do mato e traziam, depois a gente fazia. Desfiava aquele pedaço, $e$ depois cochava, formava o tipo de uma corda(...) dava pra fazer cerco, rede, tudo, porque naquele tempo não tinha meios de comprar, não tinha casa de pesca, nem se falava nisso" 
(Entrevista com a artesã Isabel Marques em Camburí, no ano de1992)

Usava-se o ubá, cipó imbé e timbopeva para amarrar os bambús que sustentavam as paredes de pau-a-pique das casas e servia também para fazer cestos. $\mathrm{O}$ cipó timbopeva era usado para fazer cestos, sobretudo o tipiti, de consistência elástica, usado para espremer a mandioca ralada:

“Tinha um cipó com nome de tingopeva, né, era pra fazê o tapeti, tipo de um balaio, pra colocá a massa que você colocava a mandioca, e colocava dentro pra espremê, depois fazia a farinha (...) Os cestos eram feitos de bambú, esse bambú que tem aí no rio e no morro. Fazia, assim, o meio dele com o tingopeva e depois ele trançava embaixo e o fundo do balaio era feito com ubá”

( Entrevista com dona Maria Aparecida de Souza em Boiçucanga, no ano de 1990)

A taboa era usada para fazer esteiras para dormir. A caixeta, por ser leve, era usada para se fazer remos e bóias para as redes de pesca:

"Colchão era esteira de taboa, que se colocava em cima de uma cama rústica, feita com 4 paus fincados no chão” ( Entrevista com o Sr. Filhinho, em 1993, no bairro de Juqueí)

“ A caixeta não usava pra nada, só usava pra fazer um remo ou bóia de rede, é madeira mole, leve. Hoje o pessoal faz artesanato”

( Entrevista com o canoeiro Giovani dos Santos, em 1997) 


\subsubsection{O surgimento do Artesanato Popular}

Durante a década de 60, um grupo de voluntários, sebastianenses e paulistanos, liderados pela senhora Nilza do Vale, criou no município de São Sebastião, uma entidade assistencialista chamada "Assistência ao Pequeno Caiçara". Essa iniciativa constitui-se como o primeiro aporte de novas técnicas, possibilitando o desenvolvimento de produtos até então inexistentes no conjunto de objetos produzidos pelos caiçaras. Novas técnicas de trançado em taboa eram repassadas para os artesãos locais, que passaram a confeccionar tapetes, bolsas e chinelos, que eram levados para venda em São Paulo. O dinheiro resultante da venda era trazido para os artesãos ou distribuído em espécie para comunidades caiçaras isoladas e carentes de atendimento à saúde. Esse trabalho foi desativado no fim da década de 70 e não houve continuidade, nem por intervenção externa, nem por mobilização dos artesãos.

Com a chegada do turismo, intensificada a partir da década de 70, o artesanato popular, com fins comerciais, foi surgindo dessa relação entre a demanda trazida pelo turismo e a oferta de objetos produzidos pelos caiçaras e caracterizando-se como o artesanato popular típico da região. Esse artesanato baseia-se em técnicas tradicionais de cestaria, trançado, entalhe, modelagem em cerâmica, tecelagem e empalhamento, utilizando matéria-prima proveniente dos remanescentes da Mata Atlântica do município. Assim, podia-se encontrar no local, objetos como cestos e balaios feitos com taquara e cipó, tapetes, bolsas e chinelos feitos com taboa, potes e panelas de barro, gamelas, tinas e pequenos objetos de madeira tais como colheres de pau, pilões e outros.

Sobre a atual produção do artesanato comercial em São Sebastião: 
"Aprendi a fazer cesto com papai e ele aprendeu com o pai dele. Hoje a gente faz pra vender, mas antigamente era só pro uso da casa”

( Entrevista com o artesão Virgulino José de Farias, no ano de 1999, em Juqueí)

"Eu uso a tamanqueira pra fazer artesanato, é uma madeira típica aqui do litoral, ela se usa pra fazer remo, colher de pau, é uma madeira que não racha e é mole de se trabalhar, é muito apreciada. Tem a caixeta, tem a canela, só que a canela é muito mole no fundo, ela tem miolo e esse miolo não é bom, e a tamanqueira não tem miolo. A caixeta, como tá proibido de cortar, está faltando, então eu uso a tamanqueira. A tamanqueira, o vento derruba muito galho, você pega, serra e deixa murchar”. ( Entrevista com o artesão Sebastião Salomão de Oliveira, no ano de 1992, no bairro da Enseada)

“Meu filho corta a taboa no brejo pra mim. Aí eu destalo tudo e estendo tudo direitinho no sol. Com 3 dias de sol tá tudo sequinho e tá pronto pra trançar. Dá pra fazer tapete, chinelo, chapéu, eu faço tudo isso"

( Entrevista com a artesã Iraci Paula dos Santos, em 1999, na praia de Boiçucanga).

Os caiçaras utilizavam a taboa para confeccionar esteiras que serviam como colchão. Essa técnica consistia na amarração da folha de taboa, esticada lado a lado formando a esteira. A partir dos trabalhos da "Assistência ao Pequeno Caiçara" os artesãos aprenderam a fazer diferentes tipos de trança, que, emendadas e costuradas, formam tapetes, chinelos, redes para descanso, forro para cadeiras, entre outros objetos. 
A cerâmica era produzida no bairro São Francisco devido à existência próxima do "barro" de qualidade própria para o feitio de panelas e potes. Com a urbanização dessas áreas essa matéria-prima ficou escassa e esse artesanato praticamente desapareceu.

“Mamãe fazia panela que ela aprendeu com a mãe dela. Minhas filhas não querem saber disso (...) dentro de casa só cozinhava na panela de barro; fazia o cuscuzeiro, panela grande, pequena, de todo jeito. Vendia muito, ia de canoa pra vender em Paraty”

(Entrevista com a artesã dona Adélia Barsoti, no ano de 1992, no bairro São Francisco)

Com relação ao artesanato feito com taboa pode-se dizer que o artesanato popular, com finalidade comercial substituiu o artesanato utilitário pois a função cumprida pelo artesanato utilitário passou a ser cumprida por outros produtos industrializados. A taboa era usada para confecção de esteiras para dormir. Hoje usa-se o colchão, mesmo entre as famílias de mais baixa renda e a taboa é usada apenas para a confecção de tapetes, bolsas, etc. O mesmo não ocorre com as panelas de barro, que são feitas para a venda e para o uso da família.

\section{$O$ artesanato de caixeta}

$\mathrm{O}$ artesanato com caixeta, segundo depoimento de artesãos locais, iniciou-se quando um artesão local, senhor Jordão, hábil no entalhe de madeiras, a partir de uma raiz, que lhe sugeriu uma forma de pássaro, deu-lhe um acabamento e vendeu para um turista, dando início a uma crescente atividade de confecção artesanal de pássaros de madeira usados para decoração. Esse fato, ocorrido na praia da Baleia, caracterizou o bairro de Camburi, que fica ao lado, como o centro produtor de artesanato com caixeta. Os pássaros de caixeta tomaram formatos, proporções e finalidades muito variadas, 
transformando-se em objetos decorativos ou utilitários (espátulas, mexedores de bebida, etc.) usados pelos hotéis, bares e restaurantes locais, além de suvenir para os turistas que por ali passam.

“ A gente não usava muita caixeta, era só pra fazer um remo, uma gamelinha pra farinha. Esse negócio de passarinho começou com o seu Jordão, que mora ali na Baleia. Ele conta que foi pegá uma madeira no mato e tropeçou na raiz de uma árvore, aí ele pegou aquela raize cortou a ela e trouxe para casa porque achou ela parecida com um pássaro. Daí ele pegou uma faquinha e tirou um pouquinho daqui, um pouquinho dali, foi melhorando, né! E ficou um passarinho bem direitinho. Daí, ele pendurou no cipó e deixou na casa dele. Daí teve um moço, acho que é de São Paulo, que passou e gostou e levou. Depois veio mais gente querendo e outras pessoas começaram a fazer”. (Entrevista com dona Isabel, praia de Camburí, 1999)

Nesse ponto pode-se recorrer à Pereira $(\mathrm{s} / \mathrm{d})$ sobre a distinção que faz entre arte popular e artesanato. Esculpir um passarinho em uma raiz de árvore pode ser considerado uma manifestação da arte popular caiçara, a transposição de um elemento do ambiente e do imaginário do artesão, um pássaro, ao qual ele associou o formato da raiz, com uma intenção puramente estética, um ato de expressão própria, sem interesse de comercializá-la.

Embora não se possa dizer que o primeiro passarinho criado tenha um caráter étnico, de origem cultural, seu surgimento tem uma ligação com o ambiente e o universo cultural vivenciado por seu produtor, traz referências próprias da cultura local.

A reprodução desses objetos visando a comercialização representa o surgimento do artesanato popular de caixeta de São Sebastião. Esse artesanato traz esse 
conteúdo da arte popular que o originou, e, atualmente, é uma atividade econômica, cuja finalidade é a comercialização.

Segundo a conceituação de Marx (1982) pode-se identificar o surgimento do valor-de-troca desses produtos no momento em que é criado o artesanato popular de caixeta. A caixeta era utilizada para outros fins, como a produção de remos e bóias para redes, fazendo parte da economia local e tinha apenas um valor-de-uso. Com o surgimento da produção do artesanato para o comércio, a caixeta e os objetos com ela produzidos passaram a ter valor-de-troca, o que antes não possuíam.

A produção para o comércio passa a interagir com o mercado e sofrer influências a medida em que o consumidor de artesanato passa a interferir sobre o quê, como e quando produzir, como aponta Canclini (1984). Assim, tem-se o surgimento de objetos já bastante diferenciados de sua origem, caracterizando o que Canclini (1984) chama de aspecto híbrido do artesanato: aspecto étnico (sobrevivência da cultura) e aspecto econômico (objeto produzido dentro da lógica mercantil).

Os primeiros produtos a serem feitos com a caixeta foram passarinhos, que eram colocados sobre um arco de cipó, de caráter decorativo. Com o aumento da produção para a venda, outros objetos passaram a ser produzidos, com finalidade utilitária e não apenas decorativa. A introdução de tais objetos já ocorreu em função da relação da produção com o mercado local, através da solicitação dos comerciantes locais para a confecção de objetos para uso.

"Pelo que eu sei, os donos de bar e restaurante, aqui de Camburi, gostaram dos passarinhos e pediram pra fazer o socador de caipirinha”

(Entrevista com a artesã Isabel Marques, no ano de 1999, na praia de Camburí).

Outros temas e objetos foram incorporados a esses produtos. Não foi possível identificar, através das conversas informais e das entrevistas com os artesãos, em que momento foram surgindo novos objetos, no vos temas a serem trabalhados devido à dispersão das influências incorporadas e ao fato de que a introdução desses novos 
objetos ou temas ocorreu ao longo de vários anos, nas décadas de 80 e 90, sem que se tenha registrado claramente o momento e a influência específica de algum fator externo.
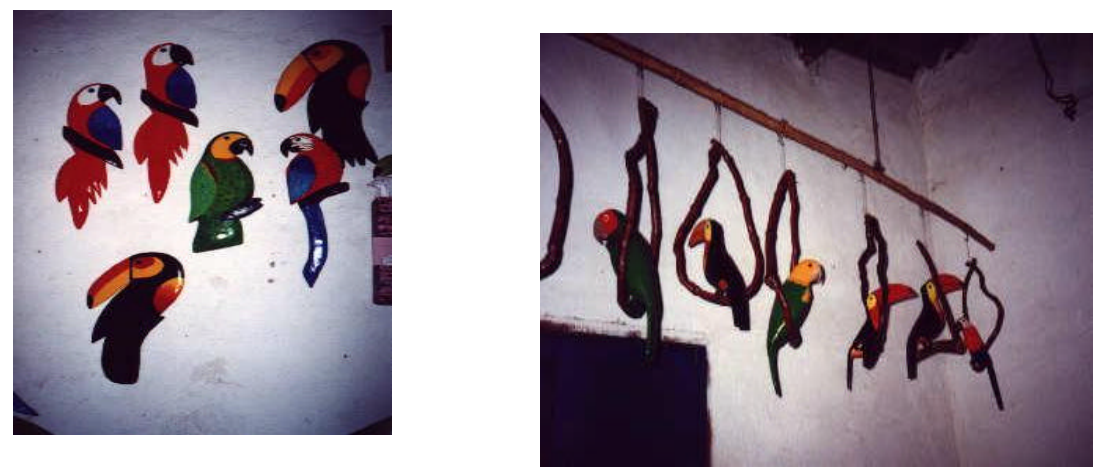

Figura 2 - Primeiros passarinhos produzidos em São Sebastião
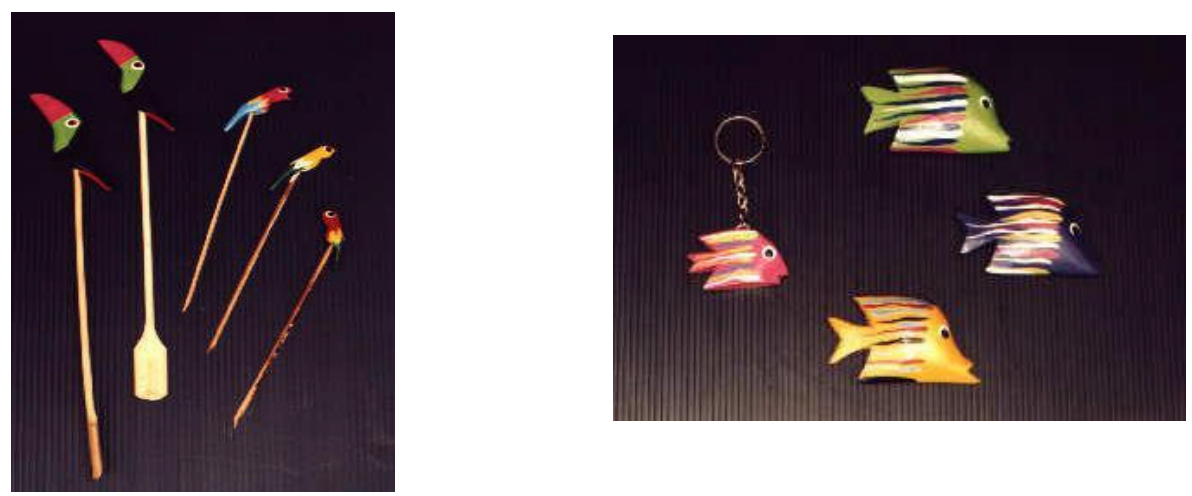

Figura 3 - Mexedores de bebida com passarinhos

Figura 4 - Chaveiros de peixe

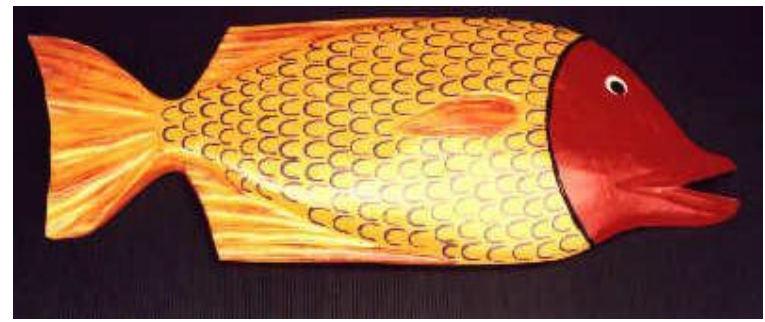

Figura 5 - Peixe para pendurar na parede

Fotos: Adriana Nolasco, 1997 
Uma exceção a esse fato foi a produção de flores de caixeta realizada por dona Luzia Marques. Essa artesã narra a história de sua criação, quando passou a produzir flores de caixeta:

“Eu só fazia passarinhos, igual aos outros. Quando aquela moça abriu aquela loja com artesanato de Bali, eu vi uma flor com pétalas grandes. As pétalas eram encaixadas com arame, todas soltas. Aí eu achei que dava pra fazer igual e fiz uma igual. Depois eu fiz aquela vermelha, a helicônia que diz, a amarela, né, e as orquídeas, tudo assim, com as folhas encaixadas” ( Entrevista com a artesã Luzia Marques, no ano de 1999, na praia de Camburí)

Esse artesanato popular de São Sebastião foi apropriado, posteriormente, por outros grupos de produtores de Silveiras, que ntroduziram novas transformações no processo de produção e nos produtos, chegando à configuração de uma pequena indústria ( o caso de Silveiras será analisado em detalhe nos próximos ítens).

A chegada ao mercado local, dos produtos de Silveiras também trouxe um novo padrão de pintura para os produtos locais. Um artesão local, Lindomar, conta que seu pai possuía várias peças que não conseguia vender e resolveu pintá-las novamente, usando as cores dos pássaros de Silveiras. Depois de pintar as peças elas foram vendidas.

Esse mesmo artesão começou a fazer as helicônias criadas por dona Luzia e passou a utilizar a folhas de uma palmeira abundante no local, a areca (Chrysalidocarpus lutescens Wendl), para a confecção das folhas que acompanham a helicônia. 

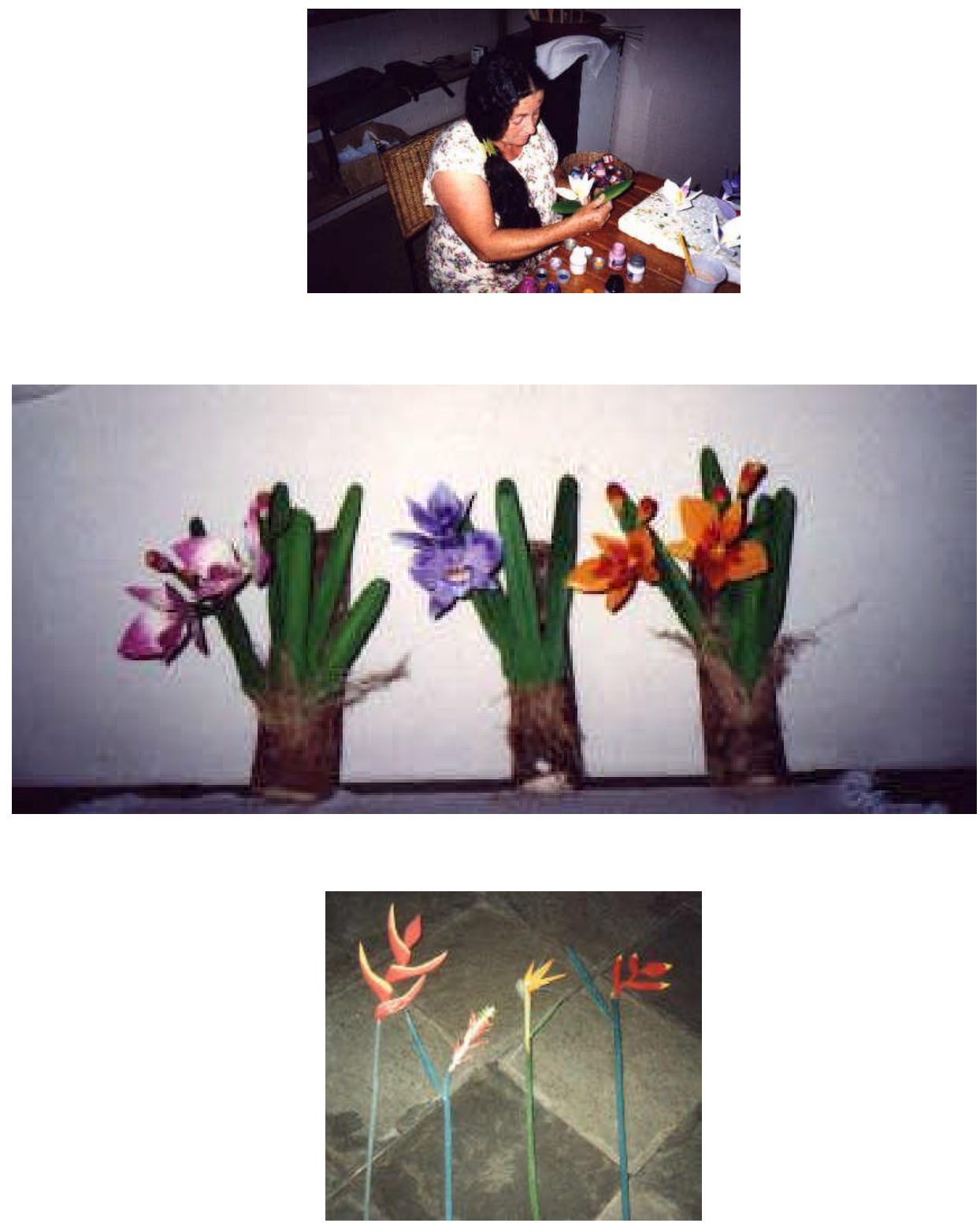

Figura 6 - Dona Luzia e as flores que criou 


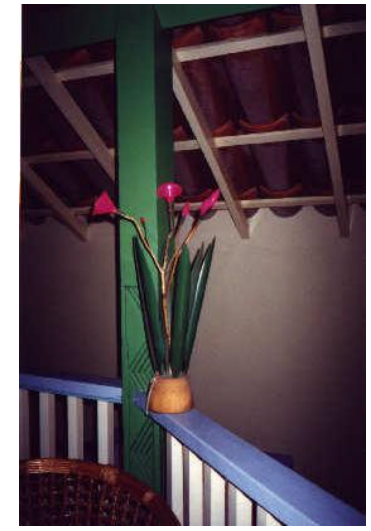

Figura 7 - Flores criada por dona Sebastiana

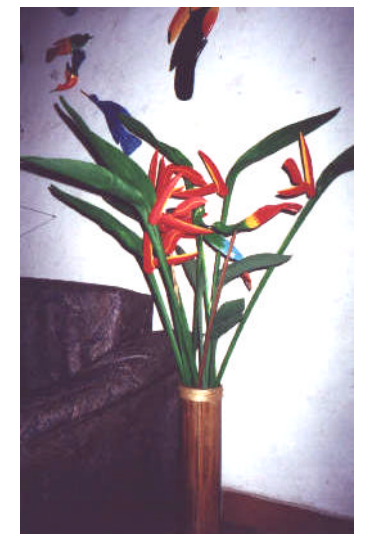

Figura 8 - Helicônias do Lindomar

Linda e Juarez, um casal de artesãos, receberam um pedido para fazer penduradores de toalha em que o suporte tivesse o formato de um peixe, de um modelo vindo de $\mathrm{Bali}^{2}$, que foi trazido pela compradora. O peixe foi copiado e feito conforme a encomenda.

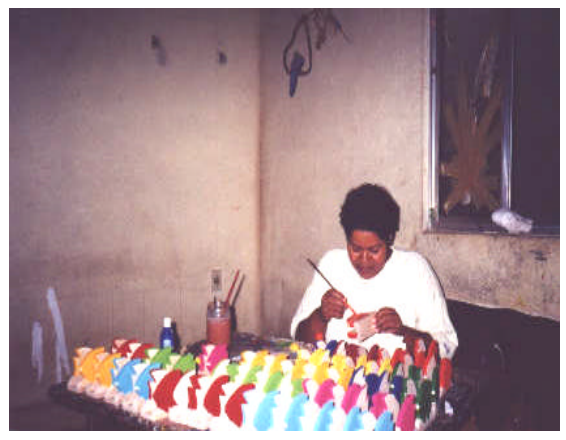

Figura 9 - Linda faz artesanato em sua na casa

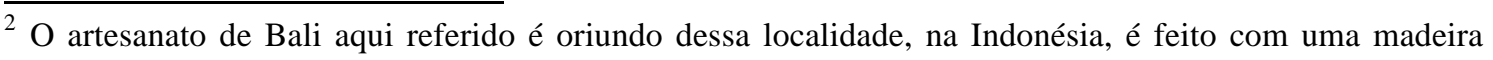
com propriedades físicas parecidas com a caixeta, encontrada no local e também representa objetos da natureza como plantas e animais. Ficou muito comum encontrá-lo nas lojas de artesanato.
} 
Esse processo de transformação e incremento do artesanato local deurse a partir da influência de fatores externos à produção, que foram incorporados, copiados e reelaborados pelos artesãos locais dentro do conjunto de referências culturais ainda existentes, relações específicas do artesão com o ambiente, relações com o mercado e influências externas diferenciadas trazidas pelo turismo ( moda, esportes, etc.).

A entrada de diferentes produtos artesanais no mercado local, como o artesanato de Bali, também é um fator que contribuiu para o enfraquecimento da comercialização do artesanato local. Tais produtos ocupam um nicho de mercado fazendo forte concorrência com o artesanato caiçara pois possuem a mesma temática, e bom acabamento.

Em 1997, foram levantados diferentes produtos e temas utilizados no artesanato com caixeta. Os temas são os pássaros, peixes e flores. Os produtos identificados foram, em sua maioria, utilitários e outros decorativos. Entre os utilitários: remo, espátula, fruteira, ímã de geladeira, palito para coquetel, mexedor de caipirinha, socador de caipirinha, palito para aperitivo, gamela, porta-guardanapo, suporte para chave , pendurador de toalhas. Para decoração encontrou-se: flores, árvore de cacau, árvore de jabuticaba, peças grandes para jardim, colher, garfo, concha, borboleta, barcos, canoa miniatura.

\subsubsection{Potencial de desenvolvimento da atividade}

Durante o trabalho realizado junto aos caiçaras, o que se observou é que existe um potencial de produção de artesanato de caixeta que reside nos seguintes fatos:

- Conhecimento de técnicas de entalhe na madeira. Os objetos de madeira de uso tradicional exigiam uma habilidade para entalhar diferentes peças, engrenagens, ferramentas. Essa habilidade é encontrada ainda hoje entre os mais velhos.

- Criação. Os objetos que hoje fazem parte do conjunto do artesanato popular voltado para o comércio foram criados pelos artesãos locais a partir do contato com o turismo. Entre a demanda pelos objetos típicos e a oferta de objetos produzidos para o uso da população local, artesãos locais passaram a usar a caixeta, que antes era usada para confeccionar remos e bóias, para produzir pássaros usados em decoração. 
Daí, passaram a adaptá-los em utensílios de uso doméstico desenvolvendo uma série de produtos utilitários ou decorativos de grande aceitação no mercado e que foram copiados por todos os demais produtores dentro e fora do município. Alguns artesãos locais tem mostrado sua capacidade de criar produtos novos, sem perder a autenticidade.

- Comercialização. Alguns artesãos do município possuem um sistema de comercialização que está além do mercado local, produzindo durante o ano todo. Há um mercado consumidor para esses produtos, dentro e fora do país, como mostra o crescimento da atividade em Silveiras, na última década (ver ítem 5.2).

- Matéria-prima. Atualmente todo artesanato feito no município utiliza caixeta do local. Sabe-se que a disponibilidade não é grande, mas somam um total de 45 hectares divididos em 5 caixetais. $\mathrm{O}$ suprimento da caixeta para o artesanato poderia ser de fora do município pois há muita oferta dessa matéria-prima no litoral sul de São Paulo. Esse fato não inviabiliza economicamente a produção pois é a mesma situação de Silveiras, que não possui a caixeta e compra-a em outros municípios.

Segundo estudos recentes, nas serrarias do município de Iguape, a caixeta que é serrada para o artesanato apresenta a menor taxa desperdício em relação à caixeta serrada para lápis e tamanco. A produção de artesanato torna-se importante estratégia para o uso sustentável da caixeta pois é uma atividade que agrega um alto valor ao produto e apresenta grande potencial de geração de emprego (Nolasco, 2000)

\subsubsection{A organização dos artesãos}

Os artesãos de São Sebastião, das diferentes modalidades de artesanato, formaram uma associação, em fins dos anos 80 e início dos 90, a Associação dos Artesãos e Artistas de São Sebastião. Essa Associação desfez-se por desentendimentos entre seus membros e até hoje não foi reativada. Sua finalidade era criar estratégias de comercialização para o artesanato local através de feiras dentro e fora do município, realizar cursos de aperfeiçoamento, entre outras. 
A prefeitura local, durante os anos de 1989, 1990 e 1991 realizou feiras de artesanato nos fins de semana, onde os artesãos vendiam seus produtos. Segundo os artesãos essas feiras eram uma alternativa muito boa para a realização de vendas, mas tiveram continuidade. A prefeitura chegou a adquirir barracas que foram entregues aos artesãos.

Em 1989, o Projeto Cultural São Sebastião Tem Alma (PCSSTA) implantou um programa chamado Escolas de Artesanato. As Escolas de Artesanato foram instituídas junto à rede de ensino público local, tinham como objetivo a continuidade das atividades tradicionais da cultura caiçara e visavam resgatar e perpetuar as técnicas do entalhe em madeira, cestaria e cerâmica, além de possibilitar uma futura atividade econômica. Essa iniciativa levou vários artesãos para as salas de aula onde ensinaram seu trabalho para centenas de alunos. Durante os anos em que existiram alcançaram, em média, mil alunos por ano, durante os anos de 1989 a 1997 . Os alunos participantes eram da $3^{\text {a }}$ série ao $1^{\circ}$ colegial, com uma faixa etária variando entre 9 e 20 anos de idade e eram de diferentes origens, filhos de caiçaras e dos migrantes que habitam a região.

Em 1997, esse trabalho foi ampliado e realizado em parceria com o FNMA/MMA através da implantação do Projeto "Núcleo de Educação, Pesquisa e Cultura dos Povos do mar". Esse projeto visava manter e estender as Escolas de Artesanato, mapear junto com os artesãos as áreas de ocorrência dos recursos naturais utilizados para o artesanato, realizar atividades de educação ambiental, visitas de campo (caixetais e taboais) com o intuito de promover a reflexão sobre as questões que envolvem o artesanato, entre elas, a situação dos recursos naturais, a crescente redução das áreas de caixeta, a poluição e outros.

O trabalho desenvolvido pelas Escolas de Artesanato concentrou-se no repasse de técnicas e não pôde atuar em outros aspectos da produção e da valorização da atividade como um todo, principalmente na organização dos artesãos. $\mathrm{O}$ restabelecimento da Associação dos Artesãos era um fator fundamental para se iniciar um processo para a instituição de uma Reserva Extrativista para a caixeta no município. Tais atividades não foram desenvolvidas pelo PCSSTA por falta de recursos financeiros. 
A manutenção e a valorização de aspectos culturais, entre eles, o artesanato, necessita de uma valorização do artesanato como atividade produtiva e também uma valorização do artesão como um profissional. Essa valorização e reconhecimento se dariam a partir dos resultados econômicos advindos da atividade, servindo como estímulo à produção. Embora esse trabalho de resgate e repasse de técnicas tenha estimulado muitos jovens na ocasião, ele necessitava de continuidade e do alcance desses resultados econômicos .

Durante os anos em que atuou com os artesãos o PCSSTA realizou Congressos e Encontros para discussão dos problemas enfrentados pela população caiçara local. Com relação ao uso dos recursos naturais provenientes da floresta foram levantadas muitas propostas, entre as quais, destacam-se as mais importantes:

\section{$1^{\circ}$ Congresso Caiçara - 1990}

- Desburocratização dos trâmites do processo de desapropriação das áreas de ocorrência da caixeta, em geral, de pequena extensão;

- Embargue o aterro, pelo Ministério Público, na área de ocorrência de caixeta em Camburi;

- Levantamento das áreas de ocorrência de caixeta com os nomes dos proprietários e autorização dos mesmos para extração da caixeta, devendo esse documento ser encaminhado ao DEPRN;

- Encaminhamento, à Assembléia, de documento sobre Lei do Extrativismo;

- Incentivos múltiplos às Associações e comunidades autóctones nativas que se interessem por atividades relacionadas à espécies vegetais;

- Todas as essências nativas deverão ser exploradas com projetos de manejo e obrigatoriedade de reflorestamento da essência extraída, na proporção vigente no Código Florestal;

\section{Encontro dos Povos do Mar - 1992}


- Assegurar a participação das comunidades que vivem dentro das Unidades de Conservação nas decisões a seu respeito, a continuidade de suas atividades tradicionais desde já, até que estejam suficientemente organizadas para reivindicar a formação das reservas Extrativistas com manejo sustentado;

- Que as terras de Marinha, ocupadas por comunidades tradicionais, que estejam em conflitos fundiários sejam desapropriadas em favor dessas comunidades, sob forma de Reservas Extrativistas, coibindo a especulação imobiliária;

\section{Pequeno Encontro dos Povos do Mar e da Mata Atlântica - 1993}

- Revisão da legislação em nível nacional, estadual e municipal de modo a adaptá-la às praticas das populações tradicionais;

- Criar Reservas Extrativistas Caiçaras nas áreas de ocupação e manejo dessas populações;

\section{Encontro Internacional dos Povos do Mar e da Mata Atlântica - 1994}

- Rediscussão do Projeto de Lei sobre o Sistema Nacional de Unidades de Conservação com ampla e efetiva participação das populações locais e suas organizações;

- Que sejam implantadas Reservas Extrativistas de Uso Sustentado nas áreas de utilização pelas populações locais;

- Que seja incluído o manejo dos recursos naturais pelas comunidades nos zoneamentos e planos de manejo, observando o princípio de que as comunidades devam participar na elaboração dos mesmos;

Essas ações junto aos artesãos, seja a ação da Assistência ao Pequeno Caiçara, durante os anos 60, que gerou renda durante um determinado tempo, seja da prefeitura ou do PCSSTA, nos anos 80 e 90, que possibilitaram levantamento de dados e informações sobre o artesanato, não evitaram a queda da atividade, apenas conseguiram mostrar a sua evidência. Quando essa iniciativas privilegiam apenas um dos aspectos da 
estrutura da produção, e não promovem ações associadas, no momento em que elas deixam de existir, arrastam junto todo o trabalho realizado. Esses exemplos mostram que a intervenção em processos como esse em estudo requerem estratégias para a organização do processo como um todo, que alcance a cadeia de produção, mas vai além disso. Há uma necessidade de ações que envolvam a educação da população capacitando-a para a auto-gestão dos processos, desenvolvimento de pesquisas na área e políticas públicas de incentivo à atividade.

\subsubsection{Caracterização sócio-econômica do artesão}

\subsubsection{Aspectos Gerais}

Os dados aqui apresentados referem-se a 4 momentos: 1990, 1997, 1999 e 2000 (Quadro 6). Os dados de1990 foram obtidos junto à prefeitura local e constituem um cadastro com o nome, endereço e o tipo de artesanato que os artesãos produzem. Constam desse cadastro 99 artesãos.

Os dados de 1997 foram levantados a partir do cadastro de 1990. Foi realizado um censo, partindo-se daquelas informações. Os artesãos que constam do cadastro de 1990 não foram encontrados em sua totalidade. Outros artesãos foram localizados a partir de uma rede de informações estabelecida com os artesãos contatados. Em 1997 trabalhou-se com o universo de artesãos que utilizam diferentes matérias-primas. Esses dados foram levantados através da parceria entre o PCSSTA e o Laboratório de Movelaria e Resíduos Florestais da ESALQ para o Projeto Artesãos da Mata Atlântica.

Os dados de 1999 e 2000 são relativos apenas ao artesanato de caixeta pois já faziam parte do levantamento de dados para essa dissertação.

A produção de artesanato concentra-se na costa sul do município, que são os bairros urbanizados mais tardiamente, em virtude da dificuldade acesso a esses locais. 
Os artesãos estão distribuídos nos bairros de Barequeçaba, Boiçucanga, Baleia, Cambury, Juqueí e Barra do Una. As principais matérias-primas utilizadas são a caixeta ( Tabebuia cassinoides), a taboa ( Tipha angustifolia), o bambú (Bambusa vulgaris), além de diferentes tipos de cipós, bambús, palmeiras e o barro (São Sebastião, op.cit., p.49)

Em 1990, de acordo com o cadastro da prefeitura, os artesão produziam uma diversidade de objetos tais como gaiolas, cestaria de vários materiais, objetos diversificados de taboa, chapéus e abanos feitos com a folha da brejaúva, potes e panelas de barro, além de gamelas, pássaros, pilões, canoas e outros objetos feitos com diferentes madeiras.

Entre os artesãos, 55 pessoas (48\%) trabalhavam com madeira, 17 (18\%) com taboa, $10(9 \%)$ com taquara e $17(25 \%)$ com outros materiais. Os artesãos que trabalhavam com madeira eram a maioria (Figura 10). Em 1997, o universo de pessoas que trabalhavam com artesanato diminuiu significativamente. Dos 99 artesãos de 1990, foram contatados 27, sendo que alguns destes 27 não constavam do cadastro de 1990. Dos 27 artesãos, 11 (\%) trabalhavam com caixeta, 12 (\%) com taboa, 3 (\%) com taquara e $2(\%)$ com outros materiais.

A diminuição dos artesãos que trabalhavam com caixeta é verificada em 1997 devido às restrições ao uso dessa madeira, o que fez com que a atividade fosse abandonada ou a matéria-prima substituída por tábuas comerciais, com o abandono das técnicas de entalhe e adoção de práticas de marcenaria (Nolasco \& Armelin, 1997). O número de artesãos que trabalham com a taboa aumentou proporcionalmente, em relação a 1990, em função da diminuição do número de artesãos que trabalham com madeira (Figura 11). 

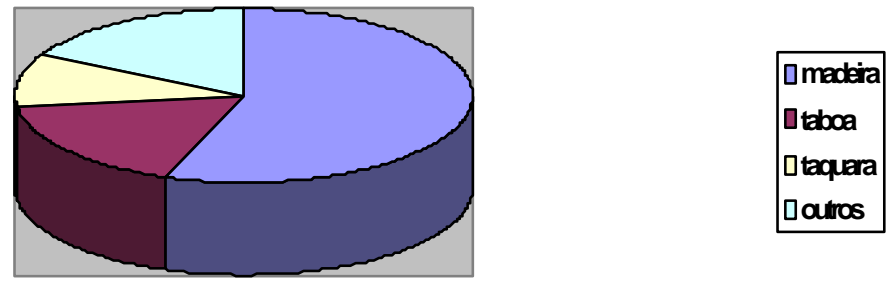

Figura 10 - Distribuição dos artesãos por matéria-prima em 1990 Fonte: (São Sebastião, op. cit., p.49; Nolasco e Armelin, $1997^{3}$ )
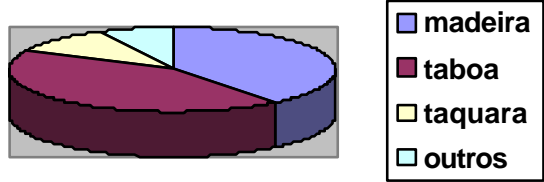

Figura 11 - Distribuição dos artesãos por matéria-prima em 1997

Fonte: (São Sebastião, op. cit., p. 49; Nolasco e Armelin, op. cit., p 78)

Os artesãos locais são predominantemente nascidos em São Sebastião. Dos 27 artesãos consultados, apenas um deles é de São Paulo e outro da Bahia. O artesanato é também uma atividade com maior incidência de mulheres. Foram identificados 12 homens e 15 mulheres nesse universo de artesãos.

Quanto ao nível de instrução, entre os artesãos entrevistados, 24 são analfabetos ou semi-alfabetizados A aprendizagem do artesanato deu-se com familiares, pais, mães, tios, avós, ou com vizinhos que faziam artesanato (São Sebastião/PCSSTA/1997; Nolasco e Armelin, 1997).

\footnotetext{
${ }^{3}$ NOLASCO, A.M. ; ARMELIN, M.J.C. Artesãos da Mata Atlântica: módulo São Sebastião. Piracicaba USP/ESALQ, 1997. 39p. (Relatório de pesquisa do Projeto “Artesãos da Mata Atlântica")
} 
Em relação à faixa etária, pode-se dizer que o artesanato é uma atividade praticada pelos mais velhos (Quadro 4). A produção de artesanato é uma atividade que não oferece estímulo aos jovens uma vez que a renda auferida com essa produção não tem sido suficiente para proporcionar melhoria na qualidade de vida dos artesãos. Por outro lado, fundamentalmente, ocorreu um rompimento com os laços culturais do passado por parte da nova geração, que, na maioria das vezes, não se identifica com as atividades que remetam à cultura tradicional. Canclini (1984) alerta para a influência que os agentes externos promovem sobre as comunidades tradicionais, propiciando mudanças na identidade cultural.

\begin{tabular}{|c|c|}
\hline Idade & \\
\hline$>$ de 40 anos & 18 \\
\hline Entre 30 e 40 anos & 7 \\
\hline Entre 20 e 30 anos & 2 \\
\hline$<$ de 20 anos & 0 \\
\hline Total & 27 \\
\hline
\end{tabular}

Quadro 4 - Idade dos artesãos em 1997

Fonte: (São Sebastião, op. cit., p. 49; Nolasco e Armelin, op. cit., p 78)

Um fator que revela-se de grande importância é o estímulo à atividade junto às novas gerações, sejam elas tradicionais, locais ou migrantes, fortalecendo o tênue laço que as liga à cultura local, valorizando o saber dos antepassados que pode ser perpetuado, através de uma atividade de importância econômica e ambiental.

A renda dos artesãos refere-se a 3 momentos desse estudo: 1997, 1999 e 2000 (Quadro 5). No ano de 1997 os dados referem-se aos artesãos que trabalham com diferentes matérias-primas. Em 1999 e 2000 os dados são referentes apenas aos artesãos da caixeta. 


\begin{tabular}{|c|c|c|c|}
\hline Renda & $1997^{*}$ & 1999 & 2000 \\
\hline Indeterminada & 9 & 4 & 4 \\
\hline Menos de 2 salários mínimos & 6 & - & - \\
\hline Entre 2 e 4 salários mínimos & 4 & - & 2 \\
\hline Acima de 4 salários mínimos & 8 & - & 5 \\
\hline Total & 27 & 4 & 11 \\
\hline
\end{tabular}

Quadro 5 - Renda dos artesãos nos anos de 1997/ 1999/2000

* Fonte: São Sebastião/PCSSTA/1997; Nolasco e Armelin, 1997).

* Artesãos que usam diversas matérias-primas

Em 1997, o artesanato representava a principal fonte de renda familiar, sendo em alguns casos a única fonte de renda entre os artesãos consultados. A renda média destas famílias, proveniente do artesanato, variava entre 1 e 4 salários mínimos, sendo que 8 apresentavam renda maior que 4 salários mínimos.

Em 1999, todos os artesãos entrevistados declararam não saber quanto auferiam com o artesanato pois a atividade estava muito enfraquecida, o que torna as vendas diluídas ao longo dos dias ou meses.

Em 2000, a atividade estava novamente aquecida, numa dimensão aproximada à encontrada em 1997, mas um pouco melhor. Os artesãos com renda maior do que 4 salários, em 2000, representavam mais da metade do total de artesãos, enquanto em 1997, os artesãos com essa renda representavam menos de um terço dos artesãos entrevistados.

Os artesãos que declaram que não conseguem determinar a renda, têm essa dificuldade em virtude da irregularidade de sua atividade. Isso significa que a renda 
obtida é pequena, possivelmente abaixo do salário mínimo ( como declarou um artesão nessa situação).

A dificuldade de estabelecer a renda deve-se à falta de controle dos custos e lucros da produção, falta de registro das vendas e à própria sazonalidade. Essa é uma característica desse sistema de produção tradicional, em que a produção do artesanato mescla-se às tarefas do cotidiano e envolve a ajuda da família.

O artesão, geralmente, possui outras atividades econômicas. A maioria, além do artesanato, trabalha como diarista ou faz "bicos". Nenhum tem emprego fixo. Arrumar um emprego fixo pode implicar no abandono da atividade.

Em 1997, 3 artesãos que trabalhavam com caixeta possuíam uma estrutura de venda e revenda de artesanato. Em 1999 esses artesãos continuavam a produzir artesanato pois estavam amparados por essa estrutura de comércio, onde, eventualmente vendiam produtos próprios.

Os artesãos que possuem loja de venda de artesanato e que trabalham com encomendas conhecem melhor a renda que possuem com o artesanato. Esses artesãos compõem o grupo de renda maior do que 4 salários Esses artesãos são facilmente encontrados pelo comprador de artesanato porque o comprador ou o turista vai até sua loja e compra seu produto. Essas lojas ficam na frente de suas casas, as vezes são os cômodos da frente da casa. Quando o artesão mora num lugar distante e sua casa não é facilmente encontrada, geralmente o comprador ou turista nem sabe que ele existe.

\subsubsection{Aspectos Particulares}

\section{Luzia Marques}

Dona Luzia é caiçara, mascida no Sertão do Camburi, São Sebastião. Foi professora na Escola de Artesanato; em 1997 tinha 57 anos, trabalhava em sua casa produzindo flores de caixeta, criadas por ela. Ela é analfabeta e aprendeu a entalhar com sua mãe há mais de 20 anos. Não sabe determinar sua renda pois suas vendas são muito dispersas. 
Em 1999 foi contatada e relatou que só estava fazendo peças por encomenda pois as vendas estavam fracas e que o artesanato de Silveiras atrapalhava muito.

Em 2000 foi novamente contatada e relatou que as vendas tinham melhorado e que tudo o que ela produzisse seria vendido. Dona Luzia sempre vendeu seu artesanato em casa.

\section{Jomar Moura do Prado}

Caiçara, nascido em São Sebastião, morador do bairro de Barequeçaba. Em 1997 tinha 35 anos. Possuía uma renda de $\mathrm{R} \$ 600,00 /$ mês com artesanato e $2^{\circ}$ grau completo. Em 1999 não fazia mais artesanato, tinha outro emprego.

\section{Arlinda Teixeira}

Nascida na Bahia, mora em São Sebastião há mais de 25 anos, é casada com Juarez Teixeira. Em 1997 tinha 40 anos. Ela e o marido possuem loja de artesanato em frente à casa. Tem o $1^{\circ}$ grau incompleto.

Em 1999 foi contatada e declarou que as vendas tinham diminuído muito. Estava com dificuldade para pegar caixeta e estava usando outras madeiras. Disse que a concorrência com o artesanato de Bali e Silveiras era muito grande.

Em 2000 disse que o artesanato tinha melhorado, estava vivendo do artesanato com uma renda perto de $\mathrm{R} \$ 1.400,00$ /mês junto com o marido.

\section{Benedito Tavares}

Caiçara, morador do bairro do Camburí, tinha 60 anos em 1997, casado com dona Sebastiana Tavares. Tem o $1^{\mathrm{o}}$ grau incompleto.

Seu Benedito ainda fazia artesanato em 1997, mas deixou a atividade, tem problemas de saúde que não permitem que colete a caixeta.

\section{Sebastiana Tavares}

Caiçara, moradora do bairro de Camburí, foi professora de artesanato de taboa nas

Escola de Artesanato mas não foi contatada em 1997 e 1999. É esposa de seu Benedito Tavares. Já fez muito artesanato com diferentes materiais. Tinha parado de fazer 
artesanato porque estava difícil pegar caixeta e não tem quem compre artesanato. Antes tinha barraca de venda na estrada, que agora não tem mais.

Em 2000 disse que estava fazendo apenas pássaros pequenos porque se faz com madeira pequena, fácil de pegar e transportar.

\section{Juarez Teixeira}

Caiçara, morador do bairro de Camburí, tinha 42 anos em 1997. Tem o $1^{\circ}$ grau incompleto, possui loja em frente à casa.

Em 1999 foi contatado e disse que estava fazendo mais serviços de pedreiro porque as vendas de artesanato estavam fracas. As encomendas estavam sendo feitas pela mulher. Em 2000, voltou a fazer artesanato porque as vendas tinham melhorado.

\section{Paulo Eduardo Montagner}

Caiçara, morador do bairro de Barequeçaba, tinha 24 anos em 1997. Tem o $1^{\circ}$ grau incompleto.

Em 1999 não estava fazendo artesanato.

\section{Clementino Elias Marques}

Caiçara, morador do bairro do Camburí, tinha 60 anos em 1997. É irmão de dona Luzia

e pai de Margarida Marques. Tem o $1^{\circ}$ grau incompleto e uma renda de $\mathrm{R} \$ 350,00$ /mês no ano de 1997.

Em 1999 não estava fazendo artesanato. Em 2000 voltou a fazer. Faz peças grandes, mas poucas.

\section{Margarida Elias Marques}

Caiçara, moradora do bairro de Camburí, filha de seu Clementino, tinha 30 anos em 1997. É analfabeta. Em 1999 não estava fazendo artesanato. Na lojinha que possui em frente à sua casa, estava revendendo produtos de Silveiras.

\section{José Carlos dos Santos}


Caiçara, morador do bairro de Boiçucanga, em 1997 tinha 49 anos. Tem o $1^{\text {o }}$ grau completo e uma renda mensal de $\mathrm{R} \$ 600,00$.

Em 1999 não foi contatado.

Em 2000 foi contatado e fazia artesanato com diferentes madeiras.

\section{Maria de Fátima Teixeira Soares}

Caiçara, moradora do bairro de Camburí, tinha 35 anos em 1997, é esposa de Moacir

Soares. Tem o $1^{\text {o }}$ grau incompleto e renda mensal de $\mathrm{R} \$ 600,00$ ( 1997)

Em 1999 não estava fazendo artesanato.

Em 2000 fazia artesanato, com o marido, apenas sob encomenda.

\section{Moacir Soares}

Caiçara, morador do bairro de Camburí, em 1997 tinha 40 anos. Tem o $1^{\text {o }}$ grau incompleto e renda mensal de R\$600,00, em 1997.

Em 1999 não estava fazendo artesanato.

Em 2000 fazia artesanato com a mulher. Disse que a renda compensava.

\section{Lindomar dos Santos}

Caiçara, morador do bairro de Barequeçaba, professor da Escola de Artesanato de Barequeçaba. Foi contatado em 1999. Tem o $1^{\circ}$ grau completo, possui loja em frente à sua casa e produz junto com seu pai. Ele relatou que estava trabalhando apenas com encomendas porque as vendas estavam fracas. Em sua loja revendia outros produtos. Falou da concorrência com os produtos de Bali e Silveiras.

Em 2000 foi contatado e continua fazendo seu artesanato.

\section{Nicinho dos Santos}

É pai de Lindomar, morador de Barequeçaba. Foi contatado em 2000. Ele e Lindomar fazem o trabalho separadamente. Seu Nicinho faz peças maiores, araras, tucanos. A venda é feita no mesmo local, a loja na frente da casa. 


\section{Isabel Marques}

Caiçara, foi uma das professoras de artesanato na Escola de Artesanato do Camburí. Foi contatada em 1997 e 2000. Tem feito algumas peças, apenas sob encomenda para uma outra artesã.

\begin{tabular}{|l|c|c|c|c|}
\hline \multirow{2}{*}{ Nome do artesão } & \multicolumn{5}{c|}{ Ano em que participou da pesquisa } \\
\cline { 2 - 5 } & $\mathbf{1 9 9 0}$ & $\mathbf{1 9 9 7}$ & $\mathbf{1 9 9 9}$ & $\mathbf{2 0 0 0}$ \\
\hline Luzia Marques & $\mathrm{X}$ & $\mathrm{X}$ & $\mathrm{X}$ & $\mathrm{X}$ \\
\hline Jomar Moura do Prado & & $\mathrm{X}$ & & \\
\hline Arlinda Teixeira & $\mathrm{X}$ & $\mathrm{X}$ & $\mathrm{X}$ & $\mathrm{X}$ \\
\hline Benedito Tavares & $\mathrm{X}$ & $\mathrm{X}$ & & \\
\hline Sebastiana Tavares & $\mathrm{X}$ & & & $\mathrm{X}$ \\
\hline Juarez Teixeira & $\mathrm{X}$ & $\mathrm{X}$ & $\mathrm{X}$ & $\mathrm{X}$ \\
\hline Paulo Eduardo Montagner & & $\mathrm{X}$ & & \\
\hline Clementino Elias Marques & $\mathrm{X}$ & $\mathrm{X}$ & & $\mathrm{X}$ \\
\hline Margarida Elias Marques & $\mathrm{X}$ & $\mathrm{X}$ & & \\
\hline José Carlos dos Santos & $\mathrm{X}$ & $\mathrm{X}$ & & $\mathrm{X}$ \\
\hline Maria de Fátima Teixeira Soares & $\mathrm{X}$ & $\mathrm{X}$ & & $\mathrm{X}$ \\
\hline Moacir Soares & $\mathrm{X}$ & $\mathrm{X}$ & & $\mathrm{X}$ \\
\hline Lindomar dos Santos & & & $\mathrm{X}$ & $\mathrm{X}$ \\
\hline Nicinho dos Santos & $\mathrm{X}$ & & & $\mathrm{X}$ \\
\hline Isabel Marques & $\mathrm{X}$ & & & $\mathrm{X}$ \\
\hline Jordão Camargo dos Santos & $\mathrm{X}$ & & & \\
\hline Erondino Lêdo & $\mathrm{X}$ & & & \\
\hline Total & 14 & 11 & 4 & 11 \\
\hline
\end{tabular}

Quadro 6 - Artesãos consultados nos anos de 1997, 1999 e 2000

\subsubsection{Produção e comercialização}

O processo de produção como um todo envolve 3 pontos principais: a obtenção da matéria-prima, o processamento da madeira e a comercialização.

\subsubsection{Matéria-prima}

Segundo os artesãos, a obtenção da caixeta é a principal dificuldade para a produção de artesanato. A coleta da caixeta é uma tarefa difícil devido às condições dos caixetais. Para algumas mulheres e homens, mais idosos, a entrada no caixetal é 
impossível, ou mesmo o corte e o transporte da madeira, que é um serviço pesado. Alguns artesãos, devido a essas razões, conseguem que outras pessoas coletem essa madeira. Podem ser pessoas da família, que nada cobram por esse serviço, mas podem ser ainda um serviço terceirizado. Há pessoas que cortam a caixeta e vendem-na para o artesão. Há também artesãos que coletam sua própria caixeta.

Em 1997, dos 11 entrevistados, usuários da caixeta, 7 declararam que compram e coletam a caixeta, enquanto 4 apenas coletam ( Quadro 7). Esses dados praticamente invertem-se no ano 2000 . Tal fato pode indicar a ocorrência de corte rasos de caixetais, o que aumenta a disponibilidade de caixeta, que pode ser adquirida com mais facilidade. Essa conclusão baseia-se também no depoimento dos 2 artesãos, que, no levantamento de 2000, declararam que já tinham sido avisados 2 vezes para pegar a caixeta que havia sido cortada na região.

\begin{tabular}{|c|c|c|c|}
\hline Forma de obtenção & Novembro/1997* & Junho /1999 & Março/2000 \\
\hline Compra e coleta & 7 & - & 4 \\
\hline Coleta & 4 & 4 & 7 \\
\hline Total & 11 & 4 & 11 \\
\hline
\end{tabular}

Quadro 7 - Formas de obtenção da caixeta nos anos 1997/1999/2000

* Fonte: Fonte: (São Sebastião, op. cit., p. 49; Nolasco e Armelin, op. cit., p 78)

Os artesãos apontam muitas dificuldades na coleta da caixeta. As dificuldades apresentadas variam, mas recaem, sobretudo, nas questões legais.

" Antigamente conseguia fácil, agora tá mais difícil por causa da Florestal, porque ela tá prendendo a gente de trabalhar; se não fosse o problema da Florestal tinha coisa pra gente mostrá pro pessoal”.

(Entrevista com José Carlos dos Santos, Boiçucanga, 1992) 
No quadro abaixo, os artesãos citam as maiores dificuldades encontradas para obtenção da caixeta. Cada artesão citou mais de uma dificuldade portanto a soma final de cada coluna não é o resultado da soma das dificuldades citadas, mas do número de artesãos consultados.

\begin{tabular}{|c|c|c|c|}
\hline Dificuldade & $\mathbf{1 9 9 7} *$ & $\mathbf{1 9 9 9}$ & $\mathbf{2 0 0 0}$ \\
\hline Distância & 9 & 1 & 2 \\
\hline Custo elevado de mão-de-obra & 3 & 1 & 2 \\
\hline Custo elevado de transporte & 4 & & \\
\hline Restrição legal & 11 & 4 & 6 \\
\hline Condições insalubres & 10 & & \\
\hline Problemas de saúde & 2 & 1 & \\
\hline Redução das áreas & 10 & 2 & 6 \\
\hline $\mathrm{N}^{\circ}$ artesãos consultados & 11 & 4 & 11 \\
\hline
\end{tabular}

Quadro 8 - Dificuldades assinaladas pelos artesãos nos anos 1997, 1999 e 2000

* Fonte: Fonte: (São Sebastião, op. cit., p. 49; Nolasco e Armelin, op. cit., p 78)

No levantamento de dados em março/2000, foram entrevistados 11 artesãos que estão produzindo artesanato. 2 artesãos disseram que compram a caixeta porque têm dificuldade para coletá-la e consideram que o preço pago não é alto. Nessa ocasião, pagava-se $\mathrm{R} \$ 10,00$ por um feixe de toras de $0,80 \mathrm{x} 0,10 \mathrm{~m}$. Os demais coletam no bairro de Camburí.

Nos três momentos, os artesãos, em sua maioria, citam a restrição legal e a diminuição das áreas como principais dificuldades, mostrando que a falta de acesso à caixeta é o principal fator de arrefecimento da produção de artesanato. Além desse fator, a distância aparece como um fator importante, indicando que os caixetais mais 
próximos e de mais fácil acesso já não existem mais, restando apenas os caixetais que ficam a distâncias maiores.

Devido à distância, ou à dificuldade de extrair, no caso dos mais idosos e das mulheres artesãs, ocorre a terceirização, ou seja, os artesãos pagam pela caixeta que eles mesmos não podem pegar. Outro fato que tornourse recorrente foi o uso de outros materiais em substituição à caixeta, tais como o compensado, caixas de maçã e outras madeiras encontradas em serrarias.

A falta de políticas públicas no município, que criasse um plano diretor para o uso do solo, estabelecesse áreas para o fornecimento da caixeta para o artesanato, significou a quase extinção dos caixetais locais e, consequentemente, a perda desses ecossistemas e da renda que poderia ser auferida com a produção de artesanato.

A caixeta, matéria-prima do artesanato, que é encontrada no município, está fora de Unidade de Conservação mas está em propriedades particulares. A maior parte dela encontra-se em pequenos fragmentos que permaneceram entre as áreas aterradas para construção de casas. Existem ainda áreas maiores onde a caixeta ocorre em condições ambientais bastante satisfatórias ( como está descrito no item 2.3).

De acordo com Marquesini (1999) a área com ocorrência de caixeta no município é de 45 hectares divididos em 5 caixetais. Nos levantamentos de dados disponíveis sobre a caixeta no município não constam o volume de caixeta pois não foi realizado inventário florestal. Assim, para ter-se uma idéia do que a área de caixeta existente no município representaria em termos de volume, produção, consumo, geração de renda, pode-se fazer um cálculo aproximado, baseado em dados de outras regiões do Estado.

No município de Iguape/SP, existem caixetais que possuem 30,28 mst/ha, com ciclo de corte de aproximadamente 12 anos. Projetando esse volume para São Sebastião, em 45 ha de caixeta, tem-se um estoque de 1.362,6 mst.

Com um consumo mensal de $20 \mathrm{mst}$, um produtor de Silveiras fatura mensalmente, em torno de $\mathrm{R} \$ 12.000,00$. Se projetam-se esse valores para São Sebastião, pode-se dizer que o maior artesão local, cujo faturamento fica entre $\mathrm{R} \$ 800,00$ e $\mathrm{R} \$ 1.200,00$ ( a décima parte do produtor de Silveiras), consumiria aproximadamente $10 \%$ do volume do produtor de Silveiras, o que representa 2 mst. 
Na estimativa realizada junto com o artesão e descrita adiante no item sobre o processo de produção, devem existir 30 artesãos na ativa, isto é, 15 artesãos trabalhando mais um ajudante da família para cada um. Se cada artesão consumir 1 mst, serão necessários 30 mst de caixeta por mês. Com essa caixeta cada artesão obteria uma renda mensal entre $\mathrm{R} \$ 400,00$ e $\mathrm{R} \$ 600,00$, pois teria uma produção equivalente à metade da produção do maior produtor local (2 mst para uma renda entre $\mathrm{R} \$ 800,00$ e $\mathrm{R} \$ 1.200,00$ ).

Multiplicando-se o volume de caixeta usado mensalmente, por 12 meses, temse o volume usado em um ano, que é de 360 mst. Dividindo-se o estoque local por 360 tem-se o ciclo de corte de 3,7 anos. Tal ciclo de corte é muito pequeno para um caixetal, se compararmos ao ciclo de corte do caixetal de Iguape, que é de 12 anos. Diminuindo pela metade o volume usado por cada artesão, ter-se-ia metade da renda ( $\mathrm{R} \$ 200,00$ a $\mathrm{R} \$ 300,00$ por mês) e o dobro do ciclo de corte, isto é, 7,4 anos.

Essa renda equivale à renda da maioria dos funcionários da produção de artesanato em Silveiras ( conforme descrito no item 5.3 sobre a renda dos funcionários de Silveiras) e seria também igual ou maior à renda da maioria dos artesãos de São Sebastião no momento desse estudo.

Os artesãos de São Sebastião compram ou coletam a caixeta com 10 centímetros de diâmetro. Em Silveiras, a caixeta adquirida possui o diâmetro entre 15 e $20 \mathrm{~cm}$.

Com tais cálculos, pode-se dizer que é viável vincular a produção de artesanato ao manejo sustentável da caixeta do município? Qual o diâmetro da caixeta quando alcançar 7,5 anos? Se a caixeta tiver $10 \mathrm{~cm}$ de diâmetro ela poderia ser manejada? Qual a renda que poderia ser gerada a partir do volume de caixeta existente no local? Tais questões necessitam respostas se existir o objetivo e a possibilidade de uso da caixeta local.

Outro ponto a ser lembrado é que o levantamento que identificou os 45 hectares de caixeta é de 1997, que deve ter diminuído muito nesses últimos 4 anos.

A urbanização das praias exerce forte pressão sobre os caixetais. São feitos aterros para a construção de casas e condomínios, diminuindo drasticamente as áreas de 
ocorrência da caixeta, fazendo com que o artesão tenha que buscá-las em locais cada vez mais distantes.

A extração da caixeta ocorre ilegalmente, não existindo um plano de manejo para nenhuma área. Os caixetais do município são áreas privadas e ocorre que seus proprietários encontram formas de conseguir autorização para o corte raso, aterro e construção na área. É comum ver-se às margens da rodovia a edificação de novos condomínios onde antes haviam caixetais.

Segundo depoimentos de 2 artesãos, no ano de 2000, quando há corte raso em alguma área os artesãos são chamados para "aproveitar" a caixeta, fato esse que eles consideram bom. No entanto, o que se pode observar nesse caso é que essa relação estabelecida com o artesão alimenta uma alienação e passividade diante da falta da matéria-prima.

\subsubsection{O processo de produção - processamento da madeira}

A produção ocorre no âmbito da família. A família, geralmente, ajuda na confecção, seja pintando, lixando, montando ou mesmo pegando a madeira na floresta. A produção de artesanato é manual, exceto, como tem ocorrido recentemente, com a adoção de materiais industrializados, como o compensado, que passa por uma etapa de marcenaria onde as peças são previamente cortadas. Com a falta da caixeta os artesãos locais têm usado outras madeiras para produzir o artesanato, entre elas as caixas de maçã, tábuas de compensado e sobras de madeira de serrarias.

$\mathrm{O}$ artesanato é produzido na casa do artesão. Entre os artesãos nenhum possui um espaço próprio para a produção. Quando possuem um local para a produção, trata-se de um cômodo da casa transformado para esse fim. A caixeta fica guardada em toras e é consumida de acordo com a produção.

Em 1997, o total de entrevistados que trabalhavam com caixeta em São Sebastião era de 11 artesãos. Em 2000 foram entrevistados 11 artesãos (todos trabalham com caixeta); desses, 9 eram os mesmos de 1997. No levantamento de 2000, segundo 
depoimento dos artesãos, há outros artesãos que trabalham com caixeta, mas não foram localizados. Segundo estimativa dos próprios artesãos, baseada em outros artesãos conhecidos, no momento desse estudo (abril de 2000) existam entre 15 e 16 pessoas trabalhando com caixeta. Segundo observourse e de acordo com o relato dos artesãos, todos os artesãos recebem ajuda de alguém da família. Essa ajuda é esporádica, pode ocorrer com mais de uma pessoa da família, pode passar um tempo sem que haja ajuda, ou seja, é uma ajuda irregular, de acordo com a necessidade. Fazendo-se ainda uma estimativa, a partir daquela feita pelos artesãos, pode-se pensar que hajam aproximadamente 30 pessoas envolvidas na produção de artesanato.

Os artesãos não sabem o volume de madeira que consomem porque depende das vendas, dos pedidos; esse volume pode variar muito.

Apenas um artesão declarou possuir um ajudante pago, que lhe entrega 200 peças por semana a $\mathrm{R} \$ 0,15$ cada. Em momentos de maior venda, na temporada ou encomendas, os artesãos procuram pessoas para ajudar, o que consiste numa dificuldade pois não há pessoas treinadas para as tarefas.

Aqui tem-se um exemplo de que a intervenção realizada pelo PCSSTA, com a implantação das Escolas de Artesanato, foi insuficiente na manutenção e repasse da técnica. Com o fim das atividades, nenhum aprendiz de artesão foi encontrado.

Por outro lado pode-se observar que a produção em maior escala transforma o sistema de produção à medida em que o artesão passa a terceirizar parte da produção, pagando a um terceiro para fazer uma etapa do trabalho.

\section{Preço dos produtos}

O preço final é dado sem critério, pois o artesão não tem definidas as informações acima citadas. Muitas vezes baseia-se no mercado de outros produtos, ou em conformidade com outro artesão.

Segundo os dados levantados o artesanato de São Sebastião é mais caro que o artesanato de Silveiras como pode ser comparado entre os quadros 9 e 16 . 


\begin{tabular}{|l|l|}
\hline \multicolumn{1}{|c|}{ Produto } & \multicolumn{1}{|c|}{ Valor 2 } \\
\hline Porta-guardanapo & $\mathrm{R} \$ 5,00$ \\
\hline Passarinho $10 \mathrm{~cm}$ & $\mathrm{R} \$ 1,50$ \\
\hline Pássaro 15 a 20 cm & $\mathrm{R} \$ 8,00$ \\
\hline Pássaro 25 cm & $\mathrm{R} \$ 25,00$ \\
\hline Pássaro 40-50 cm & $\mathrm{R} \$ 40,00$ \\
\hline Pássaro - 1 metro & $\mathrm{R} \$ 80,00$ \\
\hline Galho com 3 passarinhos & $\mathrm{R} \$ 5,00$ \\
\hline Mexedor bebida e socador & $\mathrm{R} \$ 2,50$ \\
\hline Ímã de geladeira, espátulas & $\mathrm{R} \$ 2,00$ \\
\hline Orquídeas - arranjo com 2 flores & $\mathrm{R} \$ 30,00$ \\
\hline Helicônias & $\mathrm{R} \$ 15,00$ \\
\hline
\end{tabular}

Quadro 9 - Preço dos produtos em São Sebastião.

\subsubsection{Comercialização}

Os artesãos possuem diferentes formas de comercialização. Alguns artesãos vendem na sua própria casa ou entregam para os lojistas locais, em consignação. Não foi registrado, nesses levantamentos, situações em que o artesão venda o artesanato para $o$ lojista local. Poucos possuem um sistema de comercialização eficiente. No ano de 2000, 4 artesãos ( 2 casais) possuem clientes fixos fora do município, para os quais trabalham sob encomenda. $\mathrm{O}$ mercado consumidor é predominantemente local, para a maioria dos artesãos, exceto para os produtores acima citados, que vendem para fora do município, 
lojistas ou atacadistas que revendem e chegam a exportar o produto. A comercialização do produto se dá de maneira informal, não havendo estratégia de comercialização.

A SUTACO (Superintendência do Trabalho Artesanal nas Comunidades), é um órgão do governo estadual ligado à Secretaria do Trabalho cuja finalidade é estimular, fomentar, financiar e promover o trabalho artesanal de comunidades como as de São Sebastião. Durante um período que vai de fins da década de 80 até a década de 90 (os artesãos não sabem precisar) a SUTACO esteve sempre presente e comprava artesanato dos artesãos de São Sebastião. Devido a alterações na sua sistemática de compras, esse órgão priorizou a compra do artesanato de Silveiras.

Nas conversas informais e entrevistas com artesãos em 1999 e 2000, eles declararam que a SUTACO não apareceu mais porque não quer comprar artesanato feito com matéria-prima extraída ilegalmente, como é o caso da caixeta em São Sebastião.

Diante desse fato da ilegalidade da caixeta, a instituição deixa de adquirir seus produtos e vai buscar artesanato em outras comunidades. Tal fato reforça a idéia de que o poder público possui políticas públicas ineficientes e contraditórias, que não agem no âmago da questão, buscando soluções, oferecendo apoio às comunidades. As políticas públicas não integram a questão ambiental com a questão da geração de renda e trabalho.

A venda de artesanato tem forte ligação com o turismo, conforme declararam os próprios artesãos, portanto, a produção de artesanato aumenta durante a temporada, que é o momento com maiores chances de venda dos produtos, dentro e fora do município. Fora dela, ao longo do ano, para os artesãos cujas vendas estão restritas ao comércio local, as vendas são muito pequenas, o que faz com que o artesão sempre tenha outra ocupação.

Em 1997, dos 11 artesãos consultados, 4 artesãos estavam exportando artesanato (através de atacadistas), 5 entregavam para a SUTACO, 4 declararam possuir ponto de venda próprio, 3 vendiam para outras lojas, e quase todos vendiam em casa (Quadro 8). A casa e a loja de venda são, as vezes, confundidas, no entendimento do artesão.

A venda para o comércio local não rompe com a barreira da sazonalidade que é um desestímulo à produção, pois leva o artesão a realizar outros trabalhos, de 
preferência um emprego fixo. O emprego fixo implica quase sempre abandono da atividade artesanal.

No levantamento realizado em 1999, apenas 3 artesãos que possuem loja de artesanato ( 2 artesãos são marido e mulher e possuem uma única loja) mantinham-se no mercado, com condições melhores de venda, conseguindo vender alguns produtos próprios. Verificou-se que nessas lojas estava ocorrendo revenda de outros produtos artesanais. Segundo depoimento do artesão a revenda é que mantém a loja, ou seja, o comércio e, em segundo plano, a produção de artesanato.

\begin{tabular}{|c|c|c|c|}
\hline Locais de venda & $1997 *$ & 1999 & 2000 \\
\hline Em casa & 9 & 1 & 11 \\
\hline Loja própria & 4 & 3 & 5 \\
\hline Loja de outros & 3 & & 2 \\
\hline Na estrada & 2 & & \\
\hline Na praia & 0 & & \\
\hline Exporta & 4 & & \\
\hline Feiras de artesanato & 1 & & \\
\hline Revendedor & 8 & & \\
\hline SUTACO & 7 & & \\
\hline
\end{tabular}

Quadro 10 - Locais de venda de artesanato em 1997/1999/2000

* Fonte: Fonte: (São Sebastião, op. cit., p. 49; Nolasco e Armelin, op. cit., p 78)

Em 2000, alguns locais de venda não eram mais utilizados pelos artesãos, como a barraca na estrada, a SUTACO, Feiras de Artesanato e outros, concentrando-se mais na venda na casa e nas lojas, próprias ou de outros comerciantes. Embora tenha sido identificado o mesmo número de artesãos em 1997 e 2000, nota-se que em 2000 as vendas estão mais restritas aos espaços privados, não estão nas praias, ruas, estradas. Tal 
fato mostra que o artesão cujas vendas restringem-se ao mercado local está cada vez menos visível na cidade de São Sebastião.

Os artesãos disseram que as vendas estavam aquecidas em 2000, sem saber atribuir esse fato a algum outro. Segundo depoimento de vários artesãos o comércio de artesanato local está saturado com os produtos de Silveiras, que podem ser encontrados em todas as lojas. A grande maioria dos produtos oriundos de Silveiras, mesmo que tenham origem em diferentes unidades de produção, não variam muito, há uma padronização do produto porque os produtores copiam uns dos outros.

No mercado local de venda de artesanato, não se faz a distinção entre os produtos dos artesãos caiçaras e os produtos de Silveiras. Nas lojas que vendem esses produtos, o comerciante procura mostrar que os produtos são do local, não fazem referência a Silveiras.

O turista que passa por São Sebastião não sabe de onde é o produto que está levando.

A inexistência de diferenciadores para o produto local, homogeneiza-os dentro do mercado e diminui suas possibilidades de venda uma vez que competem com produtos mais baratos.

Com esse panorama formado percebeu-se que os produtos das diferentes origens acabam ficando confundidos no mercado, o que prejudica o produto dos artesãos locais.

Assim torna-se necessário identificar mecanismos que possam ser usados para diferenciar tais produtos, uma vez que a produção de Silveiras, semi-industrial, pode copiar e baratear um produto.

Segundo um artesão de São Sebastião, Juarez, um dos maiores produtores locais, que possui loja e tem um sistema de comercialização mais organizado, seus clientes preferem comprar o artesanato dele pois há garantia de que são feitos com caixeta, o que resulta num produto muito melhor. Segundo declarou, o artesanato comprado em Silveiras pode ser ou não de caixeta, não está especificado e não dá para fazer essa opção. 


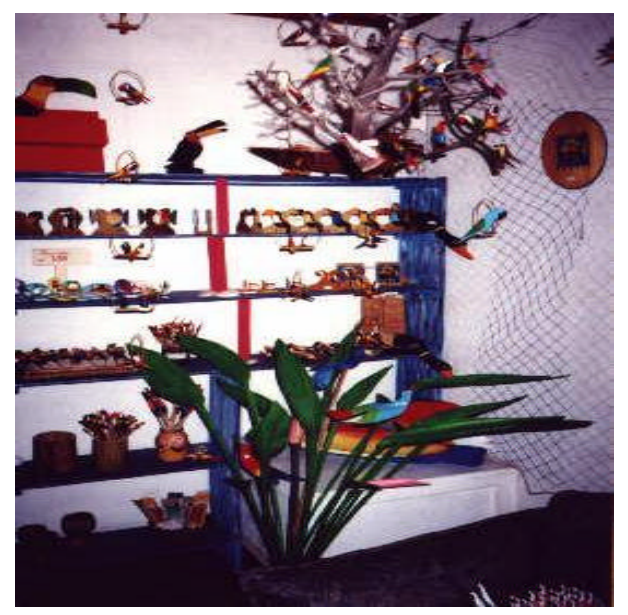

Figura 12 - Loja na casa do artesão, produtos próprios e revenda

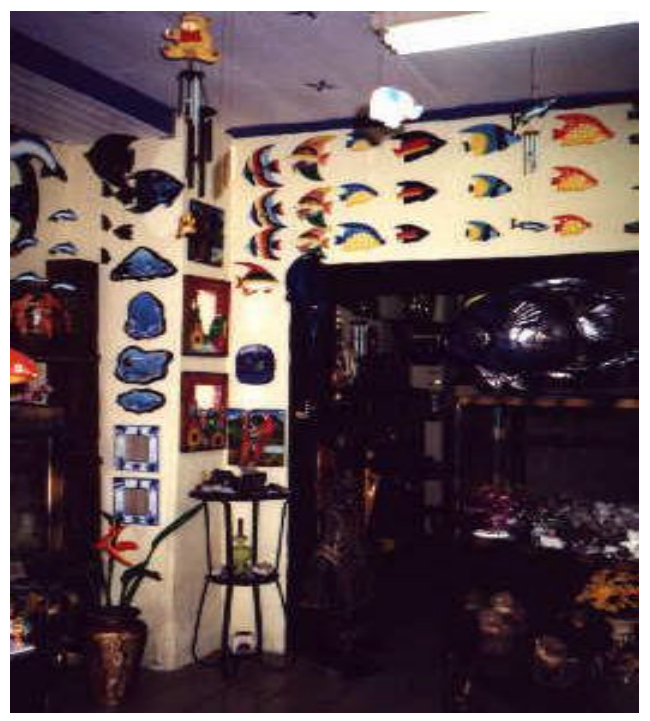

Figura 13 - Loja de artesanato do centro da cidade, venda de produtos locais e de Silveiras 
Durante um período a Prefeitura local pressionou os artesãos que possuem loja para que regularizassem o comércio, "abrindo firma", por pressão de outros comerciantes que tinham a exigência de fazê-lo. Tal fato gerava um descontentamento entre os artesãos que só vendiam seus produtos, que queriam um tratamento diferenciado para os comerciantes.

Atualmente, segundo o levantamento de dados de março de 2000, a Prefeitura não tem exigido essa regularização para quem só vende os produtos próprios, mas está pressionando para que os artesãos que possuem ponto comercial com revenda de outros produtos regularize o negócio.

$\mathrm{O}$ alto custo dos impostos e da terra impedem o artesão local de montar uma estrutura de venda. A maior parte dos artesãos que não possuem estrutura própria de venda entregam o artesanato em consignação nas lojas locais e se mistura aos seus similares vindos de Silveiras.

Não há políticas públicas locais de estímulo ao artesanato, resultando, ao contrário, numa situação em que os artesãos locais, que vendem seu artesanato na porta de casa são tratados como comerciantes comuns, dificultando suas possibilidades de venda. O poder público local não criou nenhuma alternativa para o desenvolvimento do artesanato. A falta de planejamento do uso do solo, garantindo a manutenção dos caixetais seria uma condição da maior importância, tanto para a conservação desses ecossistemas como para a produção de artesanato. As feiras, barracas de estrada e de praia estimuladas pela prefeitura local também foi um trabalho que não teve continuidade, o que, segundo os artesãos, era importante e facilitava as vendas. Finalmente, nunca foi elaborada uma política de estímulo e incentivo que abrangesse todas as modalidades de artesanato, dando assistência e formação ao artesão, fomentando a organização, criando espaços de comercialização, entre outras ações. 
com ele e o artesanato foi se mostrando uma atividade rentável, dando a resposta que aquelas pessoas procuravam.

Durante a participação numa feira em São Paulo, em 1981, na qual vendia seus produtos de sisal, vendeu também alguns pássaros de madeira produzidos por um amigo, artesão de São Sebastião. Depois da feira muitos clientes passaram a ligar e pedir os pássaros. João viu aí a possibilidade de produzir um produto pelo qual havia grande interesse.

Assim, juntou um grupo de moradores da zona rural, membros de uma família extremamente carente, os Carvalho, que já faziam trabalhos em madeira - pilões e gamelas de madeira - a quem deu treinamento, instruções sobre a escultura, pintura e acabamento.

Com esse grupo, João realizou um intenso trabalho de aperfeiçoamento, estudo com ornitólogo para aprimorar o conhecimento dos pássaros da fauna brasileira e assim foram produzidos os primeiros pássaros de madeira em Silveiras. Esse trabalho foi levado em feiras como a UD, Feira da Providência no Rio de Janeiro durante os anos de 1986 e 1987. A renda desse trabalho foi tão significativa que possibilitou à essa família a compra de um pedaço de terra.

No entanto esse trabalho foi feito com madeira local, tirada das matas da região. Os compradores reclamaram que, com o tempo, tais produtos começaram a rachar e dar bicho. João foi até São Sebastião com a intenção de saber qual a madeira usada pelos artesãos do litoral. Assim soube do uso da caixeta e passou a buscar a caixeta cortada em Caraguatatuba, São Sebastião e Ubatuba quando se faziam os aterros para a construção de condomínios.

Nessa ocasião João foi procurado pelos técnicos da REBRAF (ONG Rede Brasileira Florestal), que fazia os Planos de Manejo dos Caixetais no litoral sul do Estado, oferecendo a caixeta manejada para a produção de artesanato. Dessa forma ficou garantido o fornecimento da matéria-prima, viabilizando a produção. Os técnicos da REBRAF estiveram em Silveiras porque souberam do uso que ocorria ali. O contato com a REBRAF foi decisivo para o desenvolvimento do trabalho porque o uso da 
caixeta como matéria-prima foi fundamental para a produção, garantindo um produto melhor, com melhor acabamento, melhor qualidade e durabilidade.

Até esse momento a produção era totalmente artesanal, ou seja, todo o processo era manual, cada artesão fazia suas peças do princípio ao fim e havia o compromisso de fazer aqueles modelos que haviam sido estudados, os pássaros da fauna brasileira. Com esses produtos os artesãos freqüentaram feiras diversas e divulgaram o produto.

Segundo João Camilo o contato com feira foi fundamental para que o produto fosse conhecido. Foi esse contato que possibilitou o conhecimento da produção no município.

Porém, o acesso de lojistas, o contato direto de compradores com o grupo de artesãos fez com que o grupo se desintegrasse, e cada um passasse a produzir de acordo com o pedido do comprador, não sendo mais possível continuar orientando a produção. O lojista fazia um pedido e o artesão atendia, gerando a produção de peças diferentes dos propósitos iniciais.

Produzir artesanato se tornou um bom negócio, levando muita gente a começar a comprar peças de quem sabia esculpir para pintar e vender. Assim, muitos donos de pequenos negócios de comércio - lanchonete, padaria - começaram a produzir artesanato.Com a chegada dos compradores de artesanato os comerciantes de Silveiras, a partir da experiência da produção e do crescente interesse pelo produto, organizaram e formaram unidades de produção, que chamavam de fábrica, onde produziam artesanato, visando atender essa demanda.

Nas unidades de produção que começaram a surgir, por volta de 1986, a produção era totalmente manual, não se usavam máquinas, mas já possuía uma característica de divisão do trabalho, isto é, de manufatura (Marx, 1982) pois cada função já surgiu de forma especializada. Os donos dessas unidades compravam a caixeta, que vinha do litoral, Caraguatatuba, Ubatuba, levavam na casa dos escultores, que eram pouquíssimos, cerca de cinco ou seis pessoas, que já estavam seguindo o exemplo dos primeiros artesãos, os irmãos Carvalho, aprendendo a entalhar. Depois de entalhadas, as peças eram levadas para serem lixadas, receberem a pintura e serem colocadas na raiz. 
O passarinho no galho ( pássaro preso a uma raiz), igual ao primeiro passarinho feito pelo Sr. Jordão, em São Sebastião (como descrito no item 4.1.3 ), foi o primeiro produto e continua sendo o mais vendido até hoje.

Com a demanda sempre crescendo surgiu a necessidade de se estudar formas de aumentar o rendimento da produção. Assim começaram as primeiras tentativas de implantação de técnicas de marcenaria, introduzindo máquinas no processo produtivo. As primeiras máquinas usadas foram as lixadeiras, o que permitia um aumento do rendimento. Depois foram introduzidas as serras tico-tico para modelagem, seguidas das serras circulares e serras de fita. Tal processo dinamizou a produção que passou a ser realizada com a combinação do uso de máquinas com o trabalho manual. Os produtores locais dominaram a técnica de produzir em escala através do uso de máquinas. Assim, pode-se identificar a transformação da produção artesanal em manufatura, com o início da divisão do trabalho.

Alguns artesãos não mecanizaram sua produção e optaram pelo feitio totalmente à mão. Os Carvalho conseguiram se manter no mercado graças à sua qualidade. Os artesãos tiveram que se adaptar à nova fase de trabalho, para sobreviver. Há exemplos de artesão que mantiveram sua produção manual e não conseguem viver do artesanato. $\mathrm{O}$ artesanato local inicioutse com a produção de pássaros que eram colocados em diferentes peças utilitárias ou decorativas.

Com o tempo outros temas passaram a ser incorporados devido à própria relação com o mercado, que foi apresentando tendências e ao interesse dos produtores em produzir objetos diferentes.

Os produtores tinham que dar treinamento às pessoas pois não havia mão-de-obra qualificada para esse trabalho no local. Aos poucos foram formando escultores e pintores, que são hoje os profissionais mais qualificados para o trabalho e também os mais bem pagos. Muitos artesãos formados nas unidades foram abrindo novas unidades, aproveitando a demanda que crescia, e repetindo o mesmo processo de estruturação da produção: compra de máquinas, treinamento de pessoal, aquisição da matéria-prima, produção e venda. 
Atualmente os produtores vêm organizando suas empresas, melhorando o espaço de trabalho, organizando a situação legal das primeiras unidades de produção que surgiram como produção de "fundo de quintal".

Atualmente, segundo o levantamento de 1999, 55\% dos produtores locais possuem Micro-empresa, 18,2\% são apenas registrados na prefeitura, $10 \%$ possuem CNPJ e 18,2\% não possuem registro.

\subsubsection{A produção}

A produção de artesanato em Silveiras está dissociada da questão ambiental, mas associada ao retorno econômico que ela produz e à melhoria da qualidade de vida da população local.

A prefeitura local não possui cálculos precisos sobre a produção de artesanato no município mas estima que se produzam 200 mil peças de artesanato por mês. A agência dos Correios do município tem $70 \%$ de seu movimento com envio de artesanato local para todo o Brasil. Segundo a agência do Banespa do município o artesanato representa $30 \%$ da movimentação do banco, ficando em primeiro lugar na economia do município, seguido da agricultura e pecuária, com $20 \%$, a prefeitura com $20 \%$, o comércio com $15 \%$ e outros $15 \%$ de atividades diversas. ( comunicação pessoal do Secretário Municipal de Turismo do município de Silveiras/ Jornal Gazeta Mercantil 27/08/99).

A produção pode ser caracterizada como pequena-indústria, de acordo com a conceituação de Pereira (s/d) ou industrianato (Paraná, SEASC, 1994), pelo uso de máquinas no processo de produção. Entretanto pode-se caracterizá-la como uma manufatura, de acordo com a conceituação de Marx (1982) à medida em que é um tipo de produção que ganhou força produtiva em relação ao artesanato, devido ao seu caráter cooperativo geral e da especialização do trabalho. Tal processo atribuiu "diferentes funções para o trabalhador, estabelecendo uma hierarquia nas forças de trabalho, no grau de formação profissional, criando valores diversos e diferentes salários (Marx, 1982 "). 
A produção está dividida em etapas que começam com o desdobro da madeira em tábuas, feito na serra circular. A etapa seguinte é o risco das peças sobre a madeira e depois o corte na serra de fita e serra tico-tico e o entalhe. A próxima etapa é a lixa, depois a pintura, verniz e o acabamento final. A produção é realizada dentro e fora da unidade de produção. Os produtos que são entalhados fora da unidade de produção são mandados posteriormente para os lixadores, também em suas casas. Esses trabalhadores de fora não são funcionários das unidades de produção, não possuem relação de exclusividade, podendo pegar trabalho de diferentes unidades de produção. É um trabalho altamente especializado pois cada trabalhador só faz uma determinada etapa e só trabalha com peças de um mesmo tamanho.

O faturamento das maiores unidades de produção pode chegar a 30 mil reais na alta temporada (Quadro 11). De modo geral, o custo operacional fica entre 70 e $75 \%$ do

movimento bruto das unidades de produção. Os custos são calculados somando o valor da matéria-prima (madeira, tintas e lixas) e custo da mão-de-obra. Não foi observado se os custos de desgaste de máquinas, energia e outros ítens foram considerados.

\begin{tabular}{|l|c|}
\hline Mais de 15 mil reais/mês & 5 \\
\hline Entre 5 e 15 mil reais/mês & 4 \\
\hline Menos de 5 mil reais/mês & 2 \\
\hline
\end{tabular}

Quadro 11 - Faturamento das unidades de produção

O crescimento da produção, nos últimos meses ( dez./99 a mar./00), segundo João Camilo está ligado ao movimento de importações relativos à defasagem do cambio. Quando as importações foram liberadas, momento em que o real equiparourse ao dólar, o produto importado era muito barato, inclusive o artesanato vindo da China, da Ásia, em geral, da Indonésia, da África. O comércio de artesanato aqueceurse muito com a entrada desses produtos. Muitas lojas de artesanato foram abertas, havia uma quantidade 
grande de produtos em oferta. Quando houve a desvalorização do real frente ao dólar e os produtos importados ficaram muito caros, o mercado foi em busca dos produtos nacionais. Silveiras foi beneficiada com isso porque as vendas de artesanato aumentaram muito.

Esse aquecimento foi sentido em São Sebastião como pode ser observado no crescimento da atividade de 1999 para 2000 e em Silveiras, com um aumento de 15 a $20 \%$ por ano, segundo os produtores locais.

O crescimento da produção de artesanato em Silveiras vem se dando ao longo dos últimos anos como pode ser observado pela idade das empresas (Quadro 12). Mais da metade da produção total cresceu nessa última década.

\begin{tabular}{|c|c|}
\hline Mais de 9 anos & 4 \\
\hline Entre 4 e 9 anos & 4 \\
\hline Menos de 4 anos & 3 \\
\hline
\end{tabular}

Quadro 12 - Tempo de constituição do empreendimento

\subsubsection{Caracterização do artesão, relações de trabalho e renda}

Em Silveiras, os trabalhadores do artesanato possuem várias origens, principalmente, da zona rural. A queda da atividade agropecuária levou um número grande de pessoas a se dedicar à produção de artesanato. Essas pessoas receberam treinamento, muitas desenvolveram habilidade para o entalhamento e para a pintura.

Há também aqueles que já possuíam habilidades no entalhe de madeira e tornaram-se artesãos como é o caso da família Carvalho. Quatro membros dessa família vivem hoje do artesanato. São autônomos, não utilizam máquinas e são considerados os melhores artesãos do município. Na figura 14 vê-se um exemplo da qualidade do trabalho. 


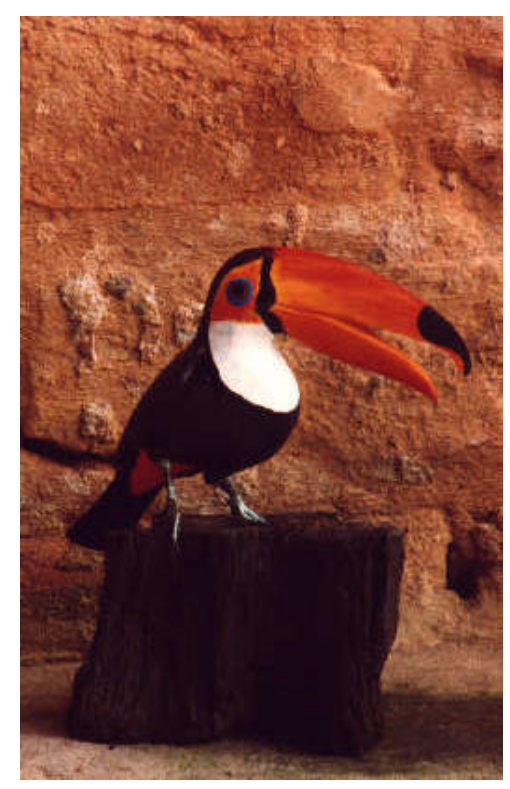

Figura 14 - Tucano feito por um dos irmãos Carvalho

Nas unidades de produção o trabalho é dividido em etapas com funcionários que trabalham dentro e fora das unidades. Quem trabalha dentro pode ser registrado ou não; pode ganhar por produção ou ser assalariado.

A prefeitura local estima que 800 a 1000 pessoas estejam envolvidas direta ou indiretamente com a produção de artesanato (comunicação pessoal do Secretário Municipal de Turismo do município de Silveiras, Jornal “O artesão”/SUTACO, set/99).

\begin{tabular}{|l|l|}
\hline Total de empregados no artesanato & 292 \\
\hline Empregados registrados & 93 \\
\hline Empregados sem registro & 71 \\
\hline Terceiros (fora da unidade) & 128 \\
\hline
\end{tabular}

Quadro 13 - Número de trabalhadores envolvidos no universo pesquisado 
No desdobro da madeira os empregados ganham salário fixo, nas outras etapas $\mathrm{s}$ funcionários ganham por produção.

A terceirização agilizou o processo de produção e o rendimento para o produtor é maior, segundo declararam. Quanto à questão trabalhista, o artesão que realiza uma etapa do trabalho em sua casa, não possui vínculos empregatícios com a empresa e portanto não goza dos benefícios da previdência social.

Com o uso de máquinas na produção aumentaram muito os acidentes de trabalho, numa média de 4 por semana no município (fonte: Posto de Saúde do município). Observou-se que muitos funcionários trabalham sem a devida proteção. Os cortadores de peças na serra de fita ganham por produção, ou seja, quanto mais cortarem, mais ganham. O uso de luvas especiais atrapalha o tato, a percepção das mãos, atrasando o trabalho. Assim, os funcionários preferem não usar luvas, o que aumenta o risco de acidentes. Os trabalhadores que operam as lixadeiras usam máscaras, os operadores de máquinas, em geral, usam protetores de ouvido, mas não foi encontrado esse equipamento em todos os funcionários. Esse fato demonstra que o trabalhador está muito desprotegido nas suas funções e mais sujeito à acidentes.

\section{Renda}

Os funcionários que trabalham dentro ou fora dos núcleos recebem, em sua maioria, por produção, isto é, ganham pelo número de peças que produzem. Os salários de quem trabalha dentro das unidades de produção, variam de 1 salário mínimo de $\mathrm{R} \$ 136,00$ ( Maio/Abril,1999) a $\mathrm{R} \$ 500,00$ por mês, variando de uma para outra unidade. Na parte do desdobro da madeira e operações com máquina o ganho fica entre $\mathrm{R} \$ 150,00$ e R\$300,00. No desdobro não há ganho por produção, o trabalhador é assalariado.

Um lixador ganha, em média, dentro ou fora da unidade de produção, R \$200,00. Na pintura o ganho varia de $\mathrm{R} \$ 190,00$ a $\mathrm{R} \$ 400,00$. No entalhe o ganho varia entre $\mathrm{R} \$ 400,00$ e $\mathrm{R} \$ 500,00$. Nas tarefas de acabamento e ajudante geral o ganho fica em torno de $\mathrm{R} \$ 160,00$ a $\mathrm{R} \$ 200,00$ e o trabalhador também não ganha por produção, é assalariado. 


\begin{tabular}{|l|l|}
\hline \multicolumn{1}{|c|}{ Atividade } & Média salarial \\
\hline Desdobro da madeira & $\mathrm{R} \$ 150,00$ a $\mathrm{R} \$ 300,00$ \\
\hline Operador de máquinas & $\mathrm{R} \$ 150,00$ a $\mathrm{R} \$ 300,00$ \\
\hline Entalhe & $\mathrm{R} \$ 400,00$ a $\mathrm{R} \$ 500,00$ \\
\hline Lixa & $\mathrm{R} \$ 200,00$ \\
\hline Pintura & $\mathrm{R} \$ 190,00$ a 400,00 \\
\hline Serviços gerais & $\mathrm{R} \$ 160,00$ a $\mathrm{R} \$ 200,00$ \\
\hline
\end{tabular}

Quadro 14 - Média salarial por atividade

\subsubsection{Processo de produção}

\section{Locais de produção}

Os locais de produção, em sua maioria são espaços domésticos adaptados para a produção (Figuras 17 e 18). Máquinas ficam em galpões de chão de terra batida.. Os locais de desdobro da madeira são os mais precários, há acúmulo de resíduos, madeira amontoada. Há produtores mais estruturados que já construíram galpões especiais para abrigar as unidades de produção, com espaços divididos e apropriados para abrigar cada etapa da produção. No caso desses locais há galpões para estocagem da madeira, desdobro e corte de máquina em geral, há salas para desenho, pintura, lixa e acabamento, escritório e venda.

\section{Etapas da produção}

\section{Entalhe}

As peças entalhadas são feitas apenas de caixeta devido às propriedades dessa madeira que são especiais para escultura o que não acontece com o pinus e o compensado, também usados na produção. $\mathrm{O}$ entalhe é feito dentro ou fora da unidade de produção. Quando é feito fora o escultor recebe a madeira cortada com um tamanho certo para o pássaro que será esculpido. $\mathrm{O}$ entalhe feito fora é especializado, havendo entalhadores que só trabalham com peças grandes ou médias ou pequenas. O entalhe é 
feito também dentro das unidades de produção. Em alguns casos a madeira que será esculpida recebe os primeiros cortes à máquina, fazendo um esboço da peça que será esculpida.

Um escultor experiente gasta 4 horas e meia para esculpir uma arara grande (40 a $50 \mathrm{~cm}$ ) e chega a fazer 2 por dia ou 10 pássaros médios. Um escultor declarou que chega a fazer 6 araras grandes no dia, das 3 horas da madrugada às 18 horas, numa média de 3 horas e meia por peça.
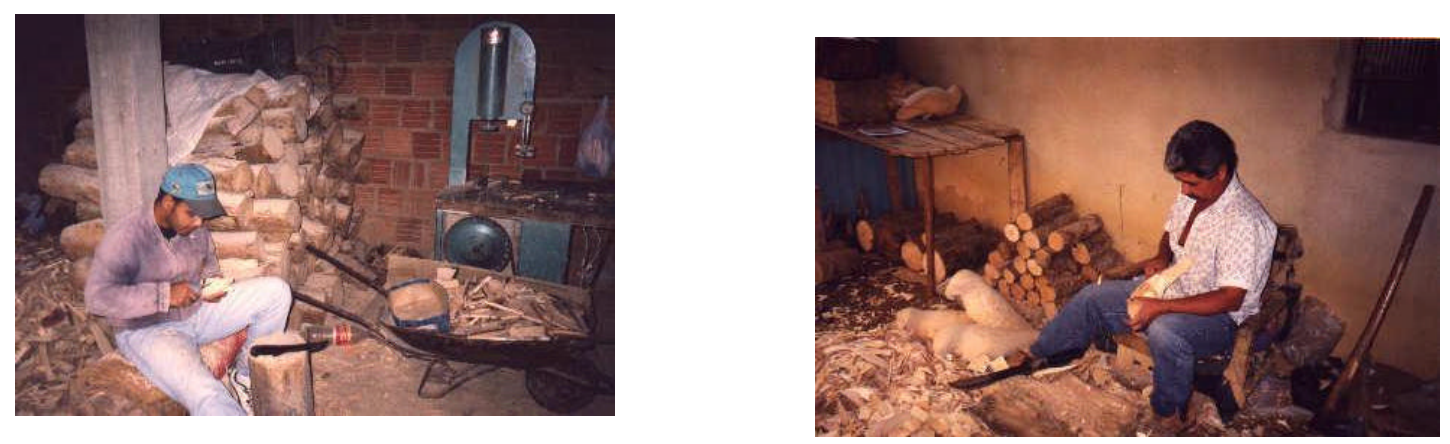

Figura 15 - Entalhe na unidade de produção

Figura 16 - Entalhe feito em casa

\section{Corte}

Algumas peças são cortadas `a máquina, Essas peças são riscadas nas tábuas de compensado ou pinus. Depois de riscadas são costadas na serra de fita (Figura 19)

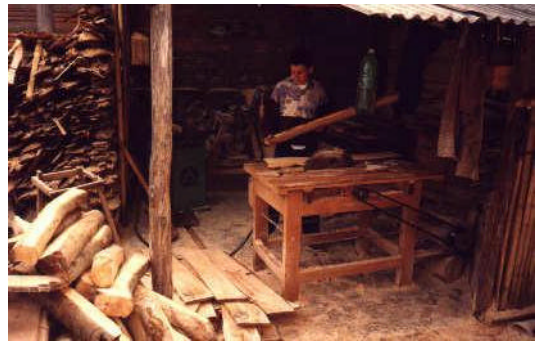

Figura 17- Corte de tábuas

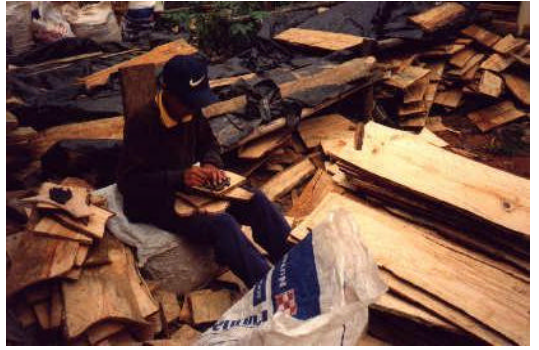

Figura 18 - Riscando as peças 


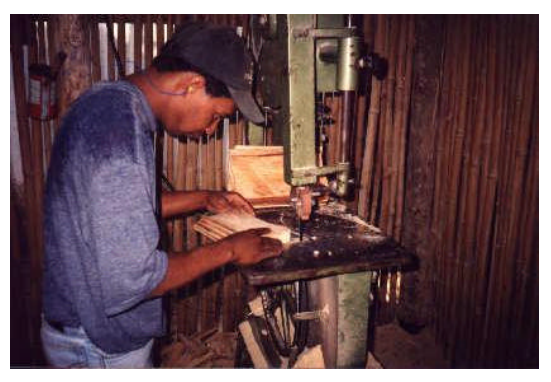

Figura 19 - Corte na serra de fita

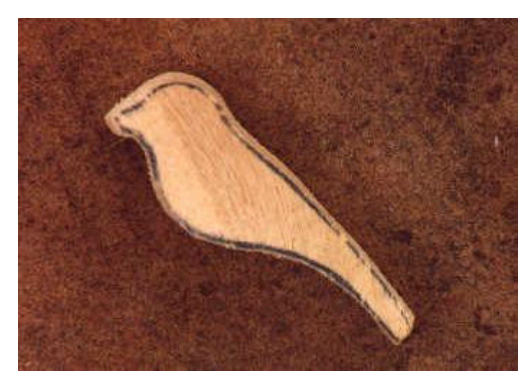

Figura 20 - Peça cortada à máquina

\section{Lixa}

Depois de esculpidas ou cortadas as peças entram na etapa de lixa. A lixa é feita à máquina ou à mão, pode ser feita dentro ou fora do núcleo de produção. Dentro dos núcleos a lixa é feita principalmente com máquinas. Fora dos núcleos a lixa é feita manualmente. A compra da lixa é por conta do produtor.

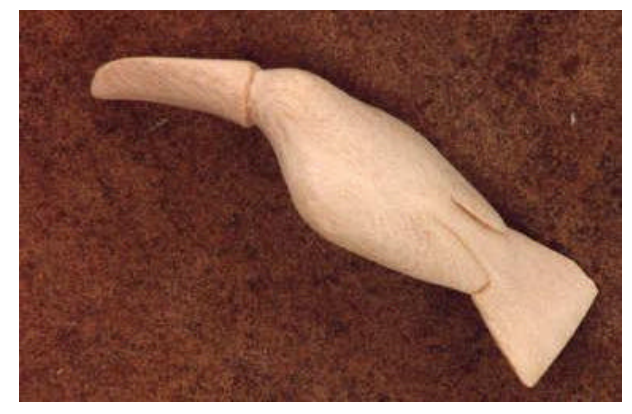

Figura 21 - Peça lixada

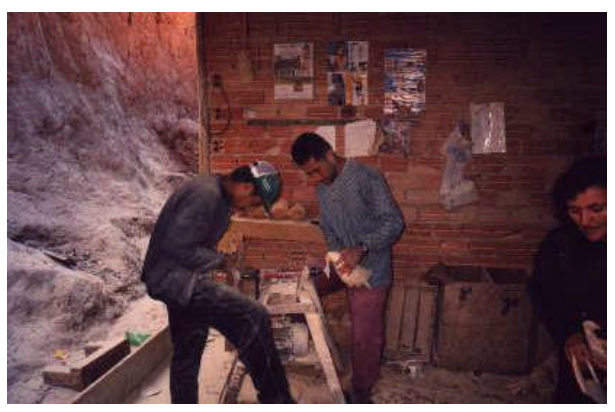

Figura 22 - Lixa feita à máquina 


\section{Pintura}

A pintura é a etapa que ocupa o maior número de pessoas e é realizada predominantemente por mulheres pois é um trabalho muito detalhado. Pode ocorrer fora das unidades, mas ocorre, predominantemente dentro delas.

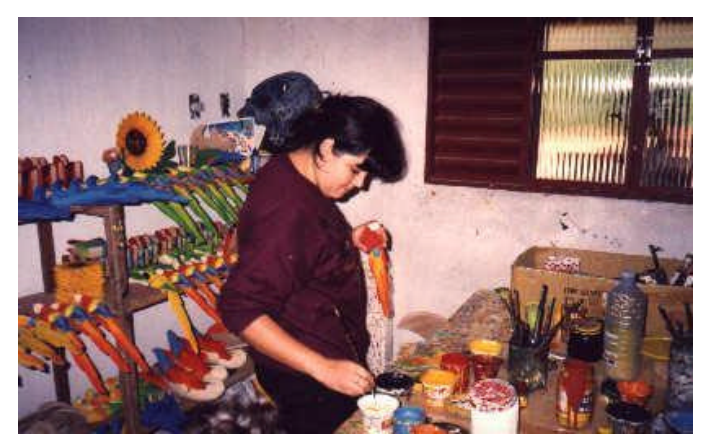

Figura 23 - Pintura das peças

\section{Acabamento}

O acabamento consiste em uma etapa onde são colocados ganchos, alças, espelhos, fios, pés dos pássaros, etc, colagem e montagem das peças quando essas são compostas por mais de um elemento e a embalagem. Do acabamento já são separados os pedidos para a entrega.

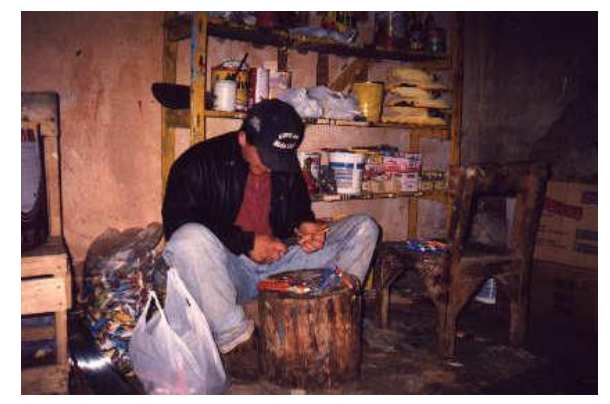

Figura 24 - Colocação de ganchos no acabamento 
Cada etapa de produção possui um valor diferenciado por exigir diferentes habilidades. As etapas cujo valor são maiores são o entalhe e a pintura pois para essas atividades são necessários treinamentos e acompanhamentos, até que o trabalhador esteja habilitado.

\begin{tabular}{|l|l|l|l|l|}
\hline \multicolumn{1}{|c|}{ Peça } & \multicolumn{1}{c|}{ Entalhar } & \multicolumn{1}{c|}{ Lixar } & \multicolumn{1}{c|}{ Pintar } & \multicolumn{1}{c|}{ Preço final } \\
\hline $\begin{array}{l}\text { Pássaro peq. } \\
(\mathbf{1 0} \text { cm) }\end{array}$ & $\mathrm{R} \$ 0,10$ a $\mathrm{R} \$ 0,12$ & $\mathrm{R} \$ 0,03$ a $\mathrm{R} \$ 0,04$ & $\begin{array}{l}\mathrm{R} \$ 0,08 \text { a } \\
\mathrm{R} \$ 0,10\end{array}$ & $\mathrm{R} \$ 0,50$ \\
\hline $\begin{array}{l}\text { Pássaro médio (15/25 } \\
\text { cm) }\end{array}$ & $\mathrm{R} \$ 0,50$ a $\mathrm{R} \$ 2,00$ & $\mathrm{R} \$ 0,20$ a $\mathrm{R} \$ 0,50$ & $\begin{array}{l}\mathrm{R} \$ 0,36 \text { a } \\
\mathrm{R} \$ 2,00\end{array}$ & $\begin{array}{l}\mathrm{R} \$ 8,00(\mathrm{em} \\
\text { média })\end{array}$ \\
\hline $\begin{array}{l}\text { Pássaro/arara grande } \\
\mathbf{( 4 0 / 5 0 ~ c m )}\end{array}$ & $\begin{array}{l}\mathrm{R} \$ 4,00 \text { a } \\
\mathrm{R} \$ 12,00\end{array}$ & $\mathrm{R} \$ 0,80$ a $\mathrm{R} \$ 1,00$ & $\mathrm{R} \$ 4,00$ & $\begin{array}{l}\mathrm{R} \$ 30,00(\mathrm{em} \\
\text { média })\end{array}$ \\
\hline
\end{tabular}

Quadro 15 - Valor pago por peça nas etapas da produção

Fonte: Levantamento de campo realizado em 1999

Entram nesses custos, os ganchos, embalagem, etc., que os produtores não têm noção. Para levantamento desses custos teriam que recorrer às notas referentes à compras de material e fazer cálculos de produção. Nenhum produtor fez esse cálculo para fornecimento desses dados. Há ainda outros ítens que são adquiridos de terceiros, especializados no seu fornecimento, que entram no custo do produto. A raiz de mexerico/cambuí, usada em todas as unidades, custa $\mathrm{R} \$ 5,00$ cada cento ou $\mathrm{R} \$ 45,00$ por milheiro. A espátula de bambú, custa $\mathrm{R} \$ 2,00$ o cento ou $\mathrm{R} \$ 15,00$ o milheiro. Os pés de arara (feitos com ferro) custam $\mathrm{R} \$ 0,20$ o par.

Os produtores apresentam números aproximados sobre seus custos pois eles mesmos declararam não saberem ao certo quanto gastam com cada item. Apenas num dos núcleos obteve-se a informação de que são gastos entre $\mathrm{R} \$ 500,00$ e $\mathrm{R} \$ 600,00$ de tinta por mês. Esse produtor tem faturamento bruto de 30 mil reais na alta temporada.

Baseado em um produtor local, cujas informações foram as mais precisas, podese relacionar alguns dados para comparação com a produção em São Sebastião ( conforme o ítem.4.6) No ano de 1998 o faturamento médio mensal desse produtor foi de 
$\mathrm{R} \$ 12.000,00$. O número de pessoas ligadas diretamente ao seu negócio é de 34 e possui um consumo de 20 metros esteres de caixeta por mês, utilizando apenas a caixeta.

\section{Preço do produto}

Os preços dos produtos variam muito de uma unidade de produção para outra. Os preços de João Camilo são mais altos. Através de suas estratégias de comercialização, ele alcança um consumidor que valoriza seu produto. No quadro 16 pode-se observar a diferença entre os preços praticados por João Camilo (Valor 1) e os preços praticados, em média, pelos demais produtores. A diferença chega a 30\% aproximadamente.

\begin{tabular}{|l|l|l|}
\hline \multicolumn{1}{|c|}{ Produto } & \multicolumn{1}{|c|}{ Valor 1 } & \multicolumn{1}{|c|}{ Valor 2 } \\
\hline Porta-copo e porta-guardanapo & $\mathrm{R} \$ 4,00$ & $\mathrm{R} \$ 2,80$ \\
\hline Passarinho 10 cm & $\mathrm{R} \$ 1,00$ & $\mathrm{R} \$ 0,80$ \\
\hline Pássaro 15 a 20 cm & $\mathrm{R} \$ 6,00$ & $\mathrm{R} \$ 4,50$ \\
\hline Pássaro 25 cm & $\mathrm{R} \$ 10,00$ & $\mathrm{R} \$ 7,00$ \\
\hline Pássaro 40-50 cm & $\mathrm{R} \$ 30,00$ & $\mathrm{R} \$ 25,00$ \\
\hline Galho com 3 passarinhos & $\mathrm{R} \$ 3,00$ & $\mathrm{R} \$ 1,50$ \\
\hline Ímã de geladeira, espátulas, mexedores & $\mathrm{R} \$ 1,00$ & $\mathrm{R} \$ 0,70$ \\
\hline
\end{tabular}

Quadro 16 - Preços dos produtos em Silveiras

O preço que se paga por peça varia de uma unidade para outra e é menor do que o preço pago em São Sebastião. Segundo seu depoimento, o artesão de São Sebastião paga $\mathrm{R} \$ 0,15$ por peça para entalhar, enquanto Silveiras paga entre $\mathrm{R} \$ 0,10$ e $\mathrm{R} \$ 0,12$. 


\subsubsection{Matéria-prima da produção}

Para a produção são utilizadas diferentes madeiras. Alguns produtores utilizam somente a caixeta, outros utilizam a caixeta, o pinus e as chapas de compensado. Esses 3 tipos de madeira entram na produção de algumas peças em diferentes pontos do processo de acordo com suas características. Há peças que utilizam apenas um tipo de madeira.

A partir dos contatos com a REBRAF alguns artesãos passaram a consumir somente a caixeta oriunda do litoral sul do estado onde há plano de manejo para extração. Os produtores locais também compram a caixeta vinda de Paraty/RJ. Essa madeira não tem um plano de manejo aprovado, constituindo-se assim numa ilegalidade. Entretanto alguns artesãos declararam que a madeira vinda de Paraty é mais mole, mais apropriada para o trabalho.

De Registro, município localizado no litoral sul do Estado de São Paulo, no Vale do Ribeira, estima-se que cheguem 35 a 50 metros esteres de madeira por mês. De Paraty estima-se que chegue uma quantia próxima a essa. Essa madeira chega a Silveiras por uma estrada que sai de Paraty vai até Cunha, e de Cunha para Silveiras.

A grande maioria dos produtores buscou outras madeiras como alternativa para baratear o custo pois a caixeta é considerada uma madeira cara. Muitas unidades de produção optaram pelo pinus e pelo compensado porque são mais baratos.

No momento de levantamento desses dados o metro estere da caixeta custava $\mathrm{R} \$ 70,00$, o pinus por volta de $\mathrm{R} \$ 20,00$. O compensado é a mais barata das madeiras porque já vem pronta para trabalhar, pode ser totalmente trabalhado à máquina. Uma folha de compensado varia entre $R \$ 15,00$ e $R \$ 35,00$ com espessura de 4 a $15 \mathrm{~mm}$.

De acordo com o levantamento realizado em 2000 tem-se os seguintes dados: 


\begin{tabular}{|l|l|}
\hline Somente caixeta & 3 \\
\hline Caixeta/Pinus/Compensado & 7 \\
\hline Pinus/Compensado & 1 \\
\hline
\end{tabular}

Quadro 17 - Número de produtores por madeira utilizada na produção

Um grande produtor local, utiliza em torno de 20 metros esteres em um mês e seu faturamento está em torno de 12 mil reais/mês. O consumo individual vai de 1/2 metro estere/mês a 20 metros esteres/mês.

\begin{tabular}{|l|l|}
\hline Caixeta & $67,5 \mathrm{st}$ ou $45,22 \mathrm{~m}^{3}$ \\
\hline Pinus & $79 \mathrm{~m}^{3}$ \\
\hline Compensado & 390 folhas \\
\hline
\end{tabular}

Quadro 18 - Consumo de madeira/mês (alta temporada)

Nesse momento eram consumidos 67,5 st de caixeta em toda a produção. Produtores locais estimam que metade dessa madeira venha de Registro, e a outra metade de Paraty; 79 metros cúbicos de pinus, 390 folhas de compensado por mês durante a alta temporada, que pode cair para $50 \%$ na baixa.

\begin{tabular}{|l|l|}
\hline 5 & Registro \\
\hline 2 & Paraty \\
\hline 3 & Registro e Paraty \\
\hline 1 & Não usa caixeta \\
\hline
\end{tabular}

Quadro 19 - Número de produtores/Origem da caixeta utilizada 
Outros materiais naturais são usados na produção. Usa-se bambú (Bambusa vulgaris) para fazer mexedores e o cambuí (raiz desse arbusto encontrado no local, considerado praga nos pastos). Destes, o bambú é uma matéria-prima que caruncha, o cambuí e a caixeta não caruncham.

O fornecimento desses materiais é terceirizado. Algumas pessoas, no município, especializaram-se na coleta e venda desses materiais.

\section{Conservação da madeira}

Quanto ao armazenamento da madeira, a forma ideal, quando ela é descarregada, é ficar num andaime. Em seguida ser colocada na posição vertical . Essa prática é recomendada e adotada por João Camilo. A maior parte dos produtores armazenam as toras nos pátios, amontoadas. Segundo depoimento de alguns produtores há perda de madeira devido ao apodrecimento de toras. A questão sobre a secagem da madeira é muito importante pois ela garante a qualidade do produto final. Muitos produtores, secam as peças ao sol, o que facilita que rachem. Segundo João o ideal é secar as peças esculpidas no sentido horizontal para que a seiva não escorra e seque lentamente. Esse procedimento evita que a peça rache. A prática mais comum entre os produtores é pendurar peças na vertical, em varais, para secar (Figura 27). Essa prática faz com que as peças rachem, fazendo com que utilize-se massa para o preenchimento das rachaduras. Estufas também são úteis para a secagem das peças porque mantém a temperatura estável. Nas estufas as peças são colocadas na horizontal Apenas um produtor do município possui uma estufa.

Se a madeira estiver na tora, com a casca, é melhor que seja seca em pé pois se ela ficar deitada pode apodrecer na parte de baixo pois a casca segura a água. 


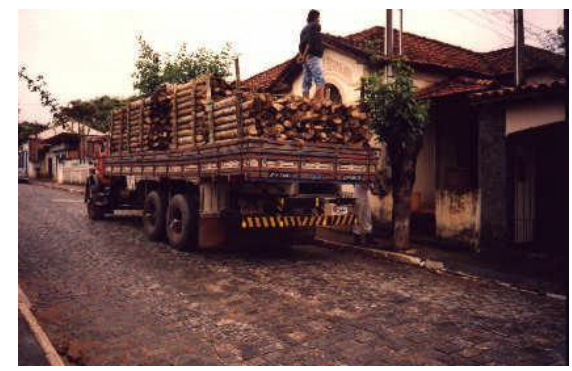

Figura 25 - Entrega da caixeta para João Camilo

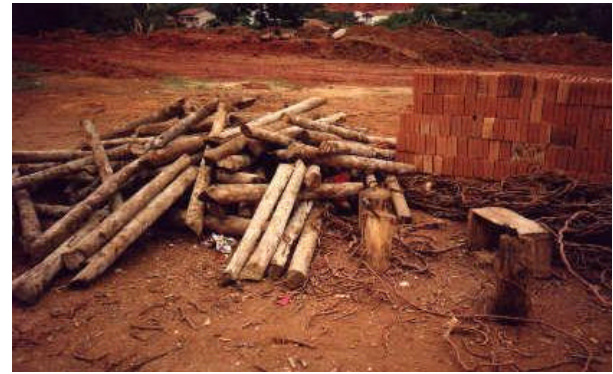

Figura 26 - Armazenagem usual

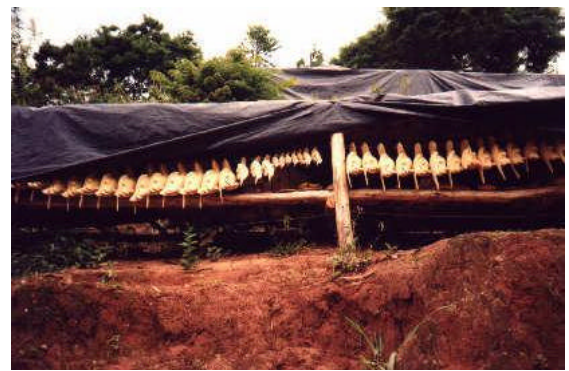

Figura 27 - Secagem das peças em varais
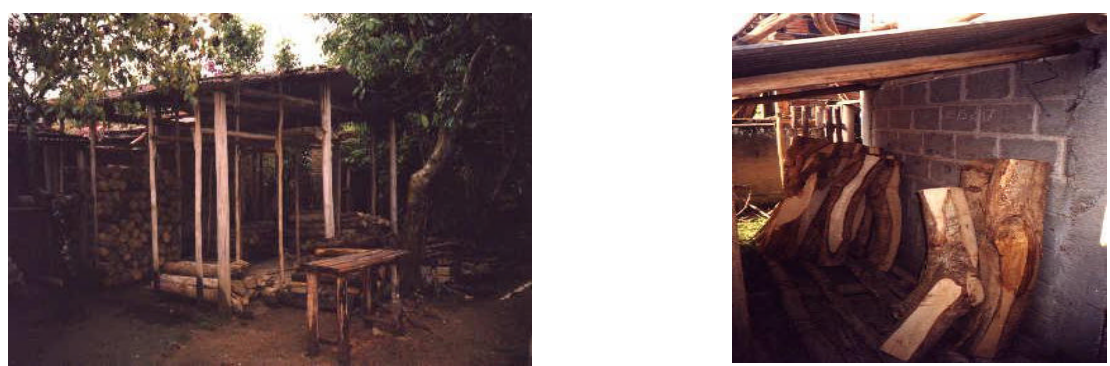

Figura 28 - Armazenamento de toras feito por João Camilo 


\subsubsection{A comercialização}

$\mathrm{O}$ artesanato de Silveiras começou a ser conhecido através de feiras que foram multiplicadoras da informação do produto. $\mathrm{O}$ trabalho com feiras, iniciado por João Camilo, abriu o espaço de comercialização no mercado para todos os produtores de Silveiras.

Os comerciantes, principalmente atacadistas, que conheceram os produtos através das feiras, passaram a procurar os artesãos locais e fazerem os pedidos. Toda a produção é feita por pedidos, praticamente não existe produto para pronta entrega.

A comercialização é uma etapa do processo que precisa ser profissionalizada, segundo avaliza João Camilo . As vendas não podem ter um caráter de relação pessoal . Essa profissionalização implica em transformar a forma de vender. A venda não é mais direta, numa relação em que o comprador dá palpite sobre o produto. O comprador faz o pedido e recebe a mercadoria.

A produção de artesanato está muito ligada ao turismo, tendo seu pico de vendas nas temporadas e feriados. A grande maioria dos produtos é vendida e revendida para cidades litorâneas. Todos os produtores declararam que vendem para todo o itoral do Brasil, e também no interior e exterior.

Todo o produto de Silveiras sai sem identificação de sua origem. Segundo os produtores, o comprador (lojista, artesãos que compram objetos semi-prontos para terminar, etc.) não quer que o consumidor saiba a origem do produto. Muitos lojistas compram artesanato sem pintar, para pintarem posteriormente, dando-lhe outras características. Aqui pode-se verificar a existência de um outro produto, um produto intermediário, o artesanato sem pintura, cuja existência ilustra como num sistema de manufatura vai se diversificando a produção. 


\subsubsection{Formas de comercialização}

\section{Venda no atacado e para lojistas}

Alguns produtores possuem vendedores próprios que saem oferecendo o produto em lojas ou repondo-o para os lojistas que já são clientes. A maior parte da produção, cerca de 70\%, em Silveiras hoje é destinada a atacadistas, revendedores de artesanato. Esses comerciantes fazem pedidos e recebem a mercadoria que revendem em lojas de todo o país ou no exterior.

Todos os produtores vendem para lojistas. Alguns através de vendedores que vão até o lojista, outros para lojistas que vão a Silveiras.

\section{Feiras}

Outros produtores optaram pela participação em feiras como forma de atingir novos mercados. Segundo João Camilo, o artesão precisa participar de feiras dirigidas ao seu produto como fazem outros profissionais pois assim pode evoluir e não ficar só copiando o que os outros fazem, pois na feira pode-se trocar técnicas, informações, etc.

Segundo avalia João,

"a feira profissional leva ao objetivo do artesão, sua proposta de comercialização. Uma feira de artesanato pode ser uma feira de praça, de rua, de clube, de cidade pequena ou uma feira grande, de um centro grande. Nessas feiras tem um público que gosta de artesanato. $O$ artesão vende seu produto no varejo e tem contato com consumidor final, uma coisa importante no trabalho. Esse contato com o consumidor final só se dá nesse momento da feira, e é fundamental que exista. Essa é a importância das Feiras de Artesanato, o contato com o consumidor e com o lojista. Quando o artesão volta para seu trabalho, ele junta as informações que colheu e pode melhorar seu 
produto”.( Entrevista com João Camilo, em Silveiras, 06/99)

\section{SUTACO}

Outra forma de comercialização em Silveiras é através da SUTACO. A SUTACO compra artesanato dos produtores locais, e também oferece outros serviços como indicação de feiras, emissão de nota fiscal, acessoria jurídica, verba para cursos e participação em feiras. Não se levantou o volume de peças adquiridas, nem os produtores de vendem para a SUTACO.

\subsubsection{Estratégias de comercialização}

\section{A escala de produção}

Segundo os produtores de Silveiras, para entrar no mercado, o artesão ou produtor de artesanato precisa ter uma produção em escala, com oferta constante e diversidade de produtos porque o mercado quer constância e novidades. $\mathrm{O}$ artesão/produtor não pode ser insensível à demanda do mercado se quiser conquistá-lo, necessitando ficar atento às suas exigências e tendências. $\mathrm{O}$ mercado pede peças de utilidade, decorativas, que custem pouco. $\mathrm{O}$ custo do produto está diretamente ligado à escala de produção.

João Camilo considera que o aumento da produção é um fator que interfere no produto final, tanto positivamente quanto negativamente. Assim, diz que:

“ o ponto positivo é o fato de que o trabalho estimula e impulsiona o artesão a produzir, a desenvolver um produto novo. O ponto negativo é que na produção em escala, com a divisão do trabalho, já não é o artesão quem faz toda a peça. A qualidade do produto final vai depender do aprimoramento das pessoas encarregadas por cada etapa. 
Muitas vezes o funcionário é apenas um trabalhador que está ali e poderia estar em qualquer fábrica ou outro trabalho, ele faz certo, mas não tem jeito, não se aprimora" (Entrevista com João Camilo, em Silveiras, 05/99)

\section{As características do produto}

João Camilo acredita que o produto tem que levar uma mensagem para $o$ consumidor, para o lojista e para o público. O produto de João tem a mensagem de que ele é feito com uma madeira de boa qualidade, com um acabamento melhor, com durabilidade maior, e que ele representa animais e plantas brasileiras. Tudo isso tem um custo diferente e esse produto tem que ser vendido por um preço diferente porque é um produto com mais valor agregado.

A estratégia de venda de João Camilo foi criar uma mensagem para seu produto. Ele só trabalha com o tema "pássaros, peixes e flores brasileiras". Ele também não vende para atacadista, porque o atacadista, segundo avalia, é um atravessador que vai entregar o produto em qualquer lugar que queira comprá-lo. Com essa estratégia ele escolhe os lugares onde seu produto será vendido porque vende direto ao lojista e assim pode conhecer também seu consumidor.

O fato de participar de feiras constantemente leva seu produto a um público diferenciado, que entende a mensagem de seu produto. Seu produto é mais caro que a média local, aproximadamente $10 \%$ do valor da peça. Esse sobre-preço deve-se ao conjunto de especificidades criadas estrategicamente por João, trabalhando dentro do tema que escolheu, utilizando apenas a caixeta e criando produtos com um design próprio.

João Camilo é o único produtor que possui essa preocupação. Todos os demais estão ligados ao mercado e suas tendências, dispostos a produzir quaisquer produtos e vender para quem se interessar em comprar. É comum encontrar, entre os demais 
produtores, objetos com o desenho do Mickey, Piu-piu, Bananas-de-pijama e outros que vão surgindo na mídia.

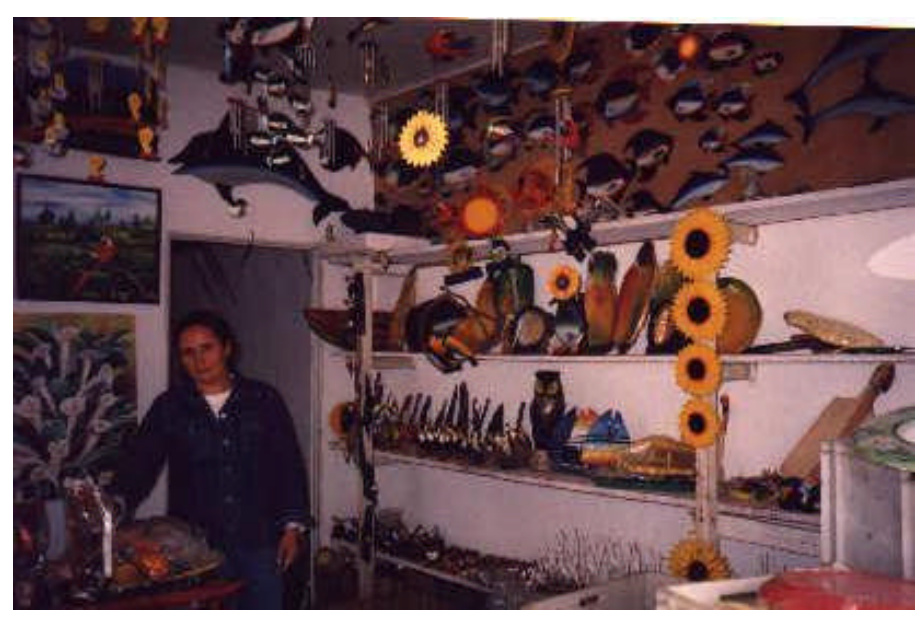

Figura 29 - Local de venda de produtor de Silveiras

\section{Sistema empresarial de produção}

João Camilo chama sua unidade de produção de atelier. Sua proposta é constituir um ateliê-empresa, onde se criam produtos, onde a produção está garantida pelo fornecimento da matéria-prima, instalações adequadas, valorização dos artesãos em todas as etapas, produtividade, eficiência, marketing. Ele ressalta a necessidade de gerenciamento da produção, feito com o planejamento de cada etapa e coordenando todo o processo. Segundo ele próprio, seu produto é resultado de um processo constante de aperfeiçoamento.

A produção de Silveiras pode ser dividida em dois tipos, pode-se dizer que há duas Silveiras. Um desses tipos é uma produção totalmente voltada para o mercado, segundo as tendências da moda e dos meios de comunicação. Novos produtos são feitos de acordo com as últimas tendências e com as demandas de mercado. Essa forma de 
produção possui um sistema de comercialização que caracteriza-se, predominantemente, pelas vendas de atacado.

O outro sistema é o adotado por João Camilo, que trabalha com um tema, que pode se alterar, mas tem uma idéia por trás. $\mathrm{O}$ artesão tem a proposta de fazer objetos referentes ao Brasil. Assim, começou fazendo pássaros brasileiros, depois peixes e flores, todos com a característica de serem representações da flora e fauna brasileiras. Há uma preocupação com a originalidade do produto. Para as vendas investe na participação em feiras, onde conhece o consumidor. Sua estratégia é vender apenas para logistas, para conhecer o público que freqüenta a loja, conhecer o local em que a loja está instalada. Ele quer um consumidor sensível à sua mensagem e que valoriza seu produto.

\subsubsection{Criação, cópia e direito}

No atelier de João Camilo existe uma preocupação grande com a criação e a qualidade dos produtos, embora ele reconheça que seu produto não é tão bem feito como aqueles esculpidos pelos artesãos que só utilizam processos manuais, como os Carvalho. Segundo o artesão, a produção em escala faz com que o produto perca qualidade. Sua intenção é aperfeiçoar as etapas de marcenaria, introduzindo máquinas lixadeiras com capacidade de melhor acabamento para que possa desenvolver um produto bem acabado, podendo dedicar-se mais aos processos manuais. João começou a exportar seu

produto e, segundo ele, o comprador de artesanato do exterior quer um produto padronizado no tamanho, cor, detalhes, etc.

Em Silveiras ocorre uma produção muito diversificada de produtos pois copia-se de tudo, desde os produtos vendidos nas ruas de Aparecida do Norte, feitos com diferentes matérias primas, produtos do Paraguai, o que aparece na televisão e nas revistas. Segundo os produtores/artesãos locais, há mercado para tudo. 

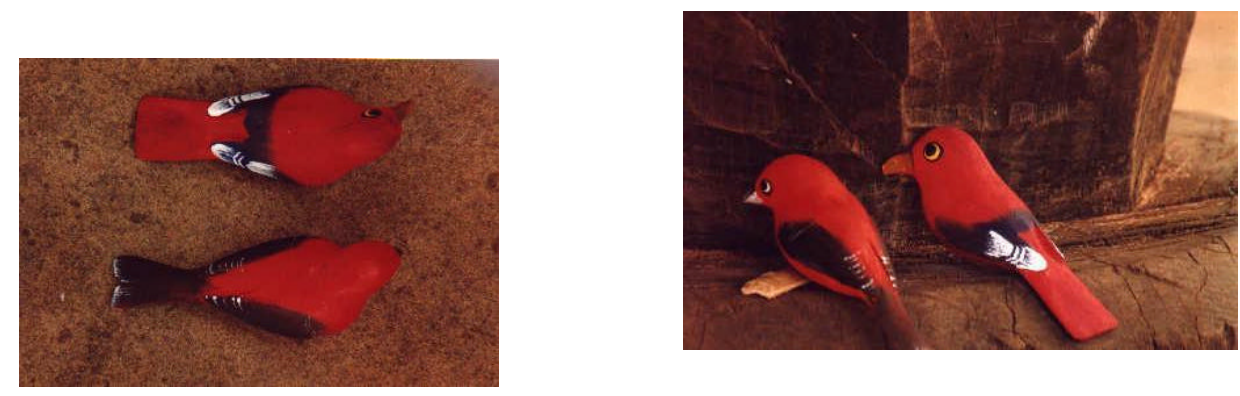

Figura 30 - A diferença na qualidade dos produtos. Acima e à direita os pássaros são feitos à máquina

Sobre a questão da cópia, que se tornou uma prática comum e motivo de reclamação de todos os produtores cabe lembrar que é uma característica intrínseca do processo de implantação da produção de artesanato local. As unidades de produção nasceram umas das outras e, consequentemente, os produtos também fizeram essa trajetória. O que se produzia na unidade original passou a ser feito na próxima unidade criada.

João Camilo, que é um designer, acredita que o artesão sempre vai ter problemas porque ele não tem como defender o seu trabalho e a sua criatividade, porque não existe direito autoral de artesão. Tudo o que é produzido por João Camilo é copiado, assim como tudo o que está nas vitrines, nas revistas, na moda. Ocorre, muitas vezes, que o próprio comerciante de artesanato vai até o atelier de João Camilo, compra algumas peças para "experimentar", leva até outro produtor e pede que a faça mais barato. O próprio comerciante faz o "tráfico da criatividade" do designer para outros produtores. Hoje ocorre essa migração da criação, de unidades que realmente criam produtos novos para outras unidades.

Os produtos estão em constante transformação; sempre haverá produção de objetos novos, muitos, inspirados pelo próprio mercado, outros mais autênticos, originais. 
"Não adianta nada você olhar o trabalho e copiar e achar que você está incorporando alguma coisa de novo fazendo uma cópia. Você pode ter idéias e desenvolver o seu trabalho em cima de uma idéia, que ela pode ser uma idéia de 200, 500 anos atrás. O garfo, a colher, ninguém inventou agora, mas tem designers novos. Então, o que falta no artesanato são designers de artesanato, porque a técnica de escultura de madeira é milenar. O homem esculpe madeira desde a idade da pedra, fazer flecha, enfim” ( Entrevista realizada com João Camilo, em 1999).

Os produtores de Silveiras tiveram a iniciativa de formar a associação para que possam trabalhar de forma mais harmoniosa, em cooperação. Há uma necessidade de resolução de problemas comuns, como a cópia, os cheques sem fundos, e algumas formas desleais de concorrência entre os próprios produtores com a interrupção de fornecimento de matéria-prima, tomar o funcionário do outro.

Entretanto, o próprio artesanato de Silveiras nasceu da cópia dos produtos dos artesãos de São Sebastião. A migração da produção de artesanato para os produtores de Silveiras ocorreu a partir da apropriação do artesanato, e em última instância, da arte popular do artesão caiçara.

A perspectiva de venda e o fato do mercado ser favorável a tais produtos acabam por criar e impulsionar processos de apropriação como esse. Passarinhos de madeira são produzidos em diferentes locais, no Estado de São Paulo e fora dele.

A partir desse estudo estima-se que o fato de se produzir esse artesanato em diferentes locais deve-se aos produtores de Silveiras. Esses produtores apropriaram-se do artesanato de São Sebastião e popularizaram-no em todo o país. O que não dá para estimar é se esse fato é bom ou não para o artesanato de São Sebastião.

Dentre as questões que permanecem sobre o assunto, tem-se a questão da garantia do "direito autoral". Quais medidas poderiam ser tomadas para garantir esse direito para o artesão? Talvez seja mais viável pensar em medidas de diferenciação do 
produto, tais como a criação de selos de qualidade para produtos de maior valor agregado, buscando nichos específicos de mercado. 


\section{DISCUSSÃO E CONCLUSÃO}

A conservação das florestas tornou-se uma das principais questões da atualidade devido à importância dos serviços ambientais que presta e ao seu potencial econômico. A conservação requer estratégias que garantam o uso dos recursos da floresta, bem como sua manutenção a longo prazo. Uma das principais estratégias que se tem nesse horizonte é o manejo florestal que pode ser praticado de forma sustentável, possibilitando compatibilizar o uso e a conservação dos recursos naturais.

Tão importante quanto a conservação das florestas é a necessidade de desenvolvimento das populações que estão direta ou indiretamente ligadas ao uso dos recursos florestais, concentradas principalmente nos países subdesenvolvidos como o Brasil, garantindo-lhes o acesso livre, legal e responsável aos recursos florestais.

O desenvolvimento social em bases sustentáveis requer, por seu lado, estratégias que viabilizem o uso dos recursos naturais, quebrando a tradição brasileira de exportação de matéria-prima e concentrando esforços no aprimoramento de sistemas que visem processar a matéria-prima, agregando-lhe valor e controlando sua comercialização que são as etapas onde são obtidos os maiores ganhos.

Essas estratégias necessitam estar coordenadas através de políticas públicas nos três níveis de governo para que as ações de diferentes áreas, ambiental, social, econômica e cultural possam ser articuladas. 
O modelo econômico que se desenvolve no Brasil tem promovido, na maioria das vezes, a degradação ecológica e a exclusão social. A implantação de grandes empreendimentos econômicos, sob a justificativa do progresso, como é o caso do turismo nas áreas litorâneas do estado de São Paulo, foi e continua sendo um processo causador de grandes impactos ecológicos e culturais que se tornaram irreversíveis, promovendo a especulação imobiliária, a poluição, inviabilizando o modo de vida da população local, marginalizando-a e concentrando a renda.

A falta de planejamento estratégico para o uso do solo e dos recursos naturais ocasionou a perda dos caixetais e, portanto, da diversidade biológica, e a perda da renda para a comunidade local.

O caiçara de São Sebastião, pescador, artesão, canoeiro ou lavrador está marginalizado social e economicamente, destituído de seus direitos ancestrais de uso dos recursos naturais, buscando formas de inserir-se economicamente e garantir sua sobrevivência.

A partir da implantação do turismo, o artesanato surgiu como atividade econômica devido à compatibilidade que essas atividades possuem. Entretanto, as condições de sustentabilidade dessa produção, sejam elas intrínsecas à produção propriamente, ou relativas ao mercado mais amplo onde ela se insere, não encontram-se articuladas, impedindo que essa atividade se consolide.

É importante pensar a produção de artesanato dentro do contexto histórico e econômico em que ela surgiu, como orientaram Pereira (1979) e Canclini(1984) afim de que não se perca a perspectiva das relações que engendraram e que implicam na sustentação dessa produção.

Quando se pensa na sustentabilidade da produção, há que se ter em vista dois aspectos. Por uma lado as relações da produção com o mercado mais abrangente e, por outro, as questões da produção propriamente. 


\subsection{Produção tradicional $x$ produção capitalista}

O artesanato de caixeta de São Sebastião, saiu da produção doméstica de objetos utilitários para a economia de mercado, cujo mecanismo de produção e consumo diferencia-se daquela, dificultando a inserção do artesão.

Nas sociedades tradicionais como a sociedade caiçara de São Sebastião, tinhase a família como unidade de produção e consumo de bens. Pais e filhos eram os responsáveis pela produção de alimento, construção da casa e dos utensílios, pela pesca, e pela vida social e cultural da comunidade em que estavam inseridos. $\mathrm{Na}$ sociedade capitalista tem-se uma estrutura de produção diferente, onde a família e a casa deixaram de ser a unidade de produção, e esta passou a ser a um local fora da casa. A produção não está voltada para suprir necessidades imediatas da família, mas para ser vendida para o consumidor.

Na sociedade tradicional a produção de objetos e utensílios era feita de acordo com as necessidades, mesclada às atividades do cotidiano, com uso de técnicas manuais recebidas de gerações passadas e o artesão detinha em suas mãos o processo de produção do início ao fim. Na estrutura de produção da sociedade capitalista o trabalhador passa a exercer uma tarefa específica e sempre repetida, e recebe um salário pelo seu trabalho.

O valor dos bens produzidos pela economia tradicional estava dado pela sua utilidade, ou seja, os bens, assim como a terra, a floresta, a lavoura, tinham valor-de-uso. $\mathrm{Na}$ economia capitalista, os bens produzidos são mercadorias, produtos que possuem valor-de-troca e podem ser comprados e vendidos no mercado.

O artesão caiçara, que conhecia apenas o jeito tradicional de produzir, ainda não decodifica o novo sistema, não domina os códigos de produção, comercialização e do consumo das camadas urbanas, que passaram a ser os consumidores de seus produtos.

O mercado tem exigências que o artesão caiçara não consegue atender pois não tem controle da produção, não tem condições de gerenciá-la afim de atender às exigências do mercado, que são a constância, a escala, a qualidade e o menor preço. 


\section{$5.2 \mathrm{O}$ artesão e o artesanato no contexto de mercado}

As observações feitas por Canclini (1984) sobre as relações socioeconômicas que envolvem a produção de artesanato podem ser identificadas no artesanato de São Sebastião. A vida social do artesão não está baseada nos moldes tradicionais pois a cultura encontra-se muito descaracterizada. Com a fragmentação da vida social dos caiçaras a partir da chegada do turismo, houve uma dissociação entre a economia e a cultura tradicional e uma reorganização da produção. Nesse processo de reorganização o artesanato passou a ser visto pelo seu valor-de-troca e significa para o artesão caiçara, principalmente, uma forma de obter renda e de inserção econômica, embora lhe dê, ainda que de forma tênue, uma identidade cultural com seus antepassados.

O artesanato de caixeta em São Sebastião existe apenas como valor-de-troca, isto é, a produção ocorre em função da comercialização, lembrando que ela nasceu dessa relação. Ela não é uma produção de caráter simbólico nem é produzida para suprir necessidades cotidianas da população. Dessa forma as implicações levantadas por Ribeiro(1984) sobre a alteração nas instituições sociais do grupo que passa a produzir artesanato "para fora" não se adequam a essa situação de São Sebastião.

As influências que o mercado podem trazer não estão no âmbito das relações culturais, mas no âmbito da produção, que pode se transformar de produção artesanal em manufatura, ou ainda descaracterizar-se ou desaparecer.

A possibilidade de produzir artesanato dá ao caiçara local a oportunidade de um trabalho mais digno do que as outras possibilidades que lhe restam dentro de seu contexto, que, na maioria das vezes, têm sido os trabalhos braçais subordinados.

Produzir artesanato não é uma atividade valorizada, como provam fatos e depoimentos de pessoas que, ao conseguirem um trabalho fixo, deixam o artesanato. A valorização do artesão e do artesanato está ligada, por uma lado, à renda que ele gera, tanto em quantidade como na regularidade, e por outro, no resgate dos valores da cultura local.

Atualmente, com a globalização do mercado, muitas decisões e movimentações financeiras que ocorrem em diferentes locais do mundo acabam por interferir na 
produção agrícola ou industrial em toda parte. A produção de artesanato não foge a essa regra. Segundo João Camilo, quando o mercado brasileiro esteve mais aberto ao artesanato de outros países, a produção de artesanato de caixeta sofreu, mas reaqueceur se em seguida, quando o mercado fechourse para tais produtos. Esse exemplo mostra como fatores externos à produção interferem e condicionam o seu desenvolvimento.

Um fator de ordem semelhante ocorreu em São Sebastião com a entrada do artesanato de Silveiras. Esses produtos entraram no comércio de São Sebastião com preços muito mais baixos, levando os logistas a preferirem comprá-los ao invés do artesanato produzido pelo artesão local, que é mais caro que o artesanato de Silveiras. Os produtores de Silveiras desenvolveram novos padrões de pintura e o consumidor aprovou esse novo padrão, levando artesãos de São Sebastião a copiá-lo para poder vender o seu produto. Assim tem-se uma situação em que as decisões sobre o quê e como produzir passaram para uma esfera que está fora e além da produção local, ou seja, passaram para o mercado, como foi discutido por Canclini(1984).

\subsection{Fatores internos condicionantes da produção de artesanato}

A produção de artesanato, no seu deslocamento para Silveiras, transformou-se numa manufatura, com a divisão e especialização do trabalho, tirando das mãos do artesão o controle do processo de produção, tirando-lhe também a posse dos instrumentos de produção, transformando-o num trabalhador assalariado, como descreveu Marx (1982). Esse processo garantiu maior produtividade e eficiência, menor preço, além de alcançar estratégias de comercialização mais estruturadas, regulares e eficientes. Tal fato alterou a própria produção em São Sebastião, que passou a adotar padrões utilizados em Silveiras.

A produção de artesanato em São Sebastião está condicionada por fatores internos e externos que impedem a organização da cadeia de produção, que começa com a disponibilidade e acesso à matéria-prima, passando pela organização da produção, até chegar na comercialização. 
A produção de artesanato em Silveiras mostrou dois exemplos distintos para organizar a produção, ambos nos moldes de uma empresa, com gerenciamento da produção, planejamento e eficiência na cadeia de produção. Um deles mais aberto ao mercado, em que tudo se produz e se vende. Outro mais resguardado das influências do mercado, baseado numa idéia e buscando o aperfeiçoamento dessa idéia, investindo na qualificação da mão-de-obra e valorização do trabalhador, em estratégias de marketing para buscar um consumidor que entende a mensagem daquele produto.

Esse segundo modelo pode ser mais interessante para o artesanato de São Sebastião uma vez que tem uma ligação com a cultura caiçara, a produção é familiar, o que pode caracterizá-lo como um produto diferenciado dentro do mercado.

\subsubsection{Aspectos ambientais e legais - O suprimento da matéria-prima}

Esse estudo revelou que a falta de matéria-prima foi um dos principais motivos que levaram o artesanato a essa situação de arrefecimento. Uma das dificuldades consiste no fato dos artesãos não serem os donos da terra, cujas posses foram vendidas, impedindo assim o acesso livre aos recursos naturais. Para suprir essa lacuna dentro do processo seria necessário garantir uma forma de acesso à caixeta.

No município de São Sebastião as áreas remanescentes de caixeta estão sendo suprimidas em função da urbanização crescente. A conservação dessas áreas surge como uma questão estratégica, quer no seu aspecto ambiental, devido à sua importância ecológica, quer no seu aspecto sócio-econômico pois representa a oportunidade de gerar renda para um grupo de artesãos locais.

A criação de uma Unidade de Conservação para os caixetais existentes é, portanto, uma medida necessária e urgente, constituindo-se como uma forma de aproveitar os recursos naturais sem esgotá-los e promover a sua conservação, assegurando um pequeno espaço aos caiçaras, que outrora possuidores dessas terras e matas, hoje ficam à margem da sociedade local, correndo o risco de ver desaparecer todo vestígio do que foi no passado sua rica cultura. 
Algumas modalidades de Unidade de Conservação podem ser estudadas e viabilizadas para o local. A Reserva Extrativista ou uma Reserva de Desenvolvimento Sustentado podem ser as opções e constituem situações concretas de barrar o desmatamento dos últimos caixetais de São Sebastião.

Muitos caiçaras, artesãos e outros habitantes e usuários dos recursos naturais da Mata Atlântica demonstraram seu anseio em todas as oportunidades que tiveram para manifestar-se, pela criação de uma Reserva Extrativista, como foi citado anteriormente a respeito dos Encontros e Congressos realizados pelo PCSSTA.

A caixeta necessária à produção poderia ser obtida através da elaboração de um Plano de Manejo para as áreas de caixeta locais, ainda que não estejam sob o controle dos artesãos. Essa medida exigiria a formação de uma associação ou cooperativa visando a solicitação do Plano de Manejo para a caixeta. A caixeta poderia ser obtida em outras regiões fornecedoras do Estado de São Paulo, de onde pode-se adquirir caixeta legalizada. Esta última alternativa fugiria da proposta de manejo da caixeta local, visando a geração de renda e a conservação desses ecossistemas, para deter-se somente na geração de renda a partir do uso da caixeta de fora do município.

Nessa questão específica do recurso natural cabe lembrar que muitas comunidades tradicionais e indígenas estão recorrendo ao artesanato como forma de estabelecer relações econômicas e culturais com o mercado. Tal ação, ao ser posta em prática, deve ocorrer mediante estudo criterioso da disponibilidade do recurso e da possibilidade de manejo afim de que não se promova a extinção de espécies, muitas delas já bastante ameaçadas, como é o caso da caixeta.

\subsubsection{Aspectos sociais - A organização dos artesãos e as intervenções de instituições externas}

É importante ressaltar que a falta de organização do grupo de artesãos de São Sebastião também é um fator que contribui para o enfraquecimento da atividade. A criação de uma Unidade de Conservação no local requer a organização política do grupo que tem interesse, além da formação de uma associação de usuários dos recursos 
naturais afim de que possam adquirir uma condição jurídica para empreender essa reivindicação. A formação dessa associação pode trazer o necessário fortalecimento político, a exemplo dos Seringueiros do Acre e das Quebradeiras de Coco do Maranhão, que tiveram seus direitos reconhecidos, constituindo-se numa força local junto à sociedade e ao poder público no sentido de lutar por políticas públicas que beneficiem a atividade.

O início da produção em Silveiras também contou com a união de artesãos que traçaram juntos uma estratégia de produção, aquisição da matéria-prima e de comercialização. Posteriormente cada artesão ou produtor local seguiu seu caminho, mas no início criaram uma forma de cooperação que os fortaleceu e viabilizou seu produto.

A organização política do grupo, através de uma associação ou cooperativa, pode propiciar o auxílio mútuo, aperfeiçoamento técnico, entre outras coisas. Essa organização é a base para o fortalecimento do grupo sob todos os aspectos. Toda e qualquer intervenção de ONGs, Universidade ou Poder Público deve considerar a organização como uma condição fundamental, promovendo processos participativos para sua consolidação.

Situações como a que se apresenta nesse estudo, isto é, a produção de artesanato, suas condições de entrada no mercado e as implicações de ordem social, cultural, ambiental e política que lhe cabem, necessitam do aporte técnico e institucional de grupos externos. O trabalho de ONGs, de Universidades, das instituições e das políticas públicas é de fundamental importância para o desenvolvimento de atividades junto a grupos como os artesãos de São Sebastião.

Essas intervenções devem estar articuladas para que seus resultados sejam reais e duradouros. A experiência obtida no PCSSTA mostrou que ações isoladas não deixam resultados a médio e longo prazos e seus resultados, mesmo no momento em que estão acontecendo são discutíveis. A cada projeto ou programa começado e não continuado esses grupos vão se desestimulando e desacreditando que tenham reais possibilidades de desenvolvimento, negando-se, as vezes, a colaborar com pesquisadores e técnicos 
quando esses chegam para realizar seus trabalhos, como já ocorreu em São Sebastião, com pescadores, que negaram-se a passar informações pelos motivos acima citados.

Dessa forma chega-se à conclusão sobre a necessidade e urgência de ações articuladas, fundamentalmente ancoradas por políticas públicas que integrem a questão ambiental com a questão do desenvolvimento social.

Grupos tradicionais ou locais, como os artesãos de São Sebastião, carentes de organização, educação e poder econômico, tem uma necessidade urgente, de receberem intervenções externas que os capacite para a autogestão de seus espaços de vida e trabalho pois a falta dessa capacidade não permite que adquiram plenamente a sua cidadania.

Os programas e projetos a serem desenvolvidos deveriam envolver esses grupos desde sua concepção, como forma de dar poder de decisão a essas populações. Sem uma participação efetiva nas tomadas de decisão essas populações continuarão marginalizadas social, econômica e politicamente.

\subsubsection{Aspectos econômicos - Produção e Comercialização}

Os artesãos de São Sebastião, em sua maioria, não estão capacitados para a auto-gestão da produção pois ainda tem uma visão parcial do processo, sua compreensão do artesanato é o "fazer". Os artesãos não tem um controle sobre a produção, sobre o tempo gasto, sobre o consumo de matéria-prima e de outros produtos, o que resulta na falta de planejamento e na baixa produtividade. Em relação à comercialização também não existe uma estratégia de venda, para todos os artesãos, que ultrapasse o mercado local e a própria sazonalidade desse mercado ou a dependência dos intermediários nas vendas do artesanato. Quando o artesão não possui um local próprio de venda é obrigado a entregar seu produto para um intermediário, logista, que é quem obtém os maiores ganhos. Tais fatores são desestimulantes para a atividade, que força o artesão a realizar outros trabalhos. 
Uma importante estratégia de mercado é ter um diferenciador para o produto local, haja visto o grande número de produtos similares que existem no mercado; esse diferenciador pode ser a certificação da caixeta ou poderiam abarcar aspectos ambientais e culturais, valorização da produção familiar, processos manuais de fabricação e outros. $\mathrm{O}$ artesanato poderia ainda ser enriquecido, valorizado e diferenciado com a incorporação de um padrão tido como de origem "étnica" ao design dos produtos. Os produtos poderiam receber rótulos que carregassem essas mensagens.

Ainda, em relação à comercialização pode-se observar os exemplos de Silveiras, com a criação de uma estratégia de comercialização que passa pelo acesso e ampliação do mercado e um projeto de marketing para o produto. Esse mercado pode ser alcançado através da participação em feiras, para se encontrar o consumidor específico do produto.

Os produtos transformam-se quando relacionam-se com o mercado pois visam atender ao consumidor. $\mathrm{O}$ artesanato tradicional nunca será o mesmo, depois que uma comunidade estabelece relações com o mercado. Se ficar dentro da comunidade pode desaparecer devido à substituição por produtos industrializados, se for comercializado vai se transformar para atender o consumidor. $\mathrm{O}$ produto utilitário original dificilmente se conservará em função do momento que se vive de interpenetração do mercado e das economias centrais e periféricas.

\subsubsection{Aspectos políticos - Políticas Públicas}

A sustentabilidade da produção de artesanato requer também políticas públicas no âmbito das diferentes esferas de governo, para o desenvolvimento de atividades produtivas que possuam uma relação direta com o uso e a conservação dos recursos naturais. A responsabilidade dos governos é muito grande na conservação das florestas e no desenvolvimento social, pois são necessárias decisões políticas para que se possam criar áreas para conservação e uso, estratégias de produção e comercialização, capacitação e educação dessas populações.

A SUTACO, enquanto órgão governamental tem também um importante papel no desenvolvimento do artesanato. Embora esteja voltada para a comercialização do 
artesanato, pode atuar junto a outras Secretarias de Estado e programas governamentais visando integrar as políticas ambientais e de desenvolvimento social.

O poder público local tem um papel importante e específico na articulação das condições de cada localidade, criando possibilidades reais e imediatas de desenvolvimento, contribuindo para a integração da questão ambiental com a geração de renda e melhoria na qualidade de vida da população.

\subsection{Artesanato : Expressão cultural x mercadoria}

A cultura caiçara sofreu drasticamente com a predominância dos valores da sociedade moderna ali presentes pela atividade do turismo. As poucas formas de expressão cultural que ainda resistem às transformações - artesanato, produção de canoas, pesca - convivem e sofrem as pressões do mercado e da legislação.

A produção de artesanato de caixeta em São Sebastião não pode ser analisada como uma expressão cultural propriamente, mas pode-se dizer que a raiz dessa produção está fincada na cultura local, como foi aqui relatado. $\mathrm{O}$ artesão não criou um objeto qualquer, mas um objeto que, embora não seja compartilhado pelo conjunto de sua comunidade como objeto utilitário, como o é uma canoa ou um tipiti, reflete as referências que ele tem de seu ambiente e de sua cultura. Aí reside sua originalidade.

$\mathrm{O}$ ato de criação do primeiro passarinho pode ser considerado uma expressão da arte popular do artesão caiçara, como sugere Pereira (1979), expressão de um universo cultural interiorizado. Objeto criado, exposto ao mundo, apreciado e vendido, novamente solicitado. Eis o início da transformação de um produto, que é o resultado de uma expressão artística, em mercadoria.

Seria legítimo, atribuir ao artesanato popular de São Sebastião essa característica de originalidade, estabelecendo um laço com a cultura local? Seria justo negar-lhe essa raiz e considerá-lo um produto como outro qualquer? Esse estudo mostra que o artesanato de São Sebastião é diferente do artesanato de Silveiras por todas as implicações de ordem cultural, ambiental, econômicas e de produção que ele possui, e 
ainda, que o artesanato de Silveiras pode ser o futuro do artesanato de São Sebastião, à medida em que, para sobreviver, o artesanato de São Sebastião tenha que transformar-se na direção da forma de produção de Silveiras. Mostra também que, no presente momento, em que o mercado e a produção de bens absorvem as culturas tradicionais e sua produção, há que se estar atento às condições em que a produção artesanal de uma comunidade tradicional ou indígena é incorporada ao mercado, passando a sofrer suas influências. Tal processo traz uma série de modificações para a cultura por transformar o produto e as relações de produção, além de transformar a relação do homem com seu ambiente. Nas comunidades tradicionais e indígenas, o ambiente é visto como um todo ordenado que supre diferentes necessidades da comunidade, sejam elas materiais ou espirituais. Com o uso intensificado de um recurso, essa visão da totalidade do ambiente pode ser transformada à medida em que o recurso utilizado ganha um valor que antes não possuía.

Quanto ao uso do recurso natural do qual o artesanato depende, à medida em que esse artesanato passa a ser produzido em maior escala, passa a haver uma pressão sobre o recurso, o que faz surgir a necessidade do manejo. A disponibilidade do recurso condiciona a produção, seja por sua sazonalidade ou pelo estoque disponível.

Cabe ainda lembrar que a questão do aumento das populações locais deve ser incorporado à discussão à medida em que o aumento da população aumenta ainda mais a pressão sobre os recursos. Tal fato remete à necessidade de diversificação da base produtiva, buscando-se diferentes alternativas para os vários recursos das florestas, além de outras atividades diferentes do artesanato.

Assim, pode-se concluir que o artesanato tradicional, ou poderá desaparecer à medida em que uma comunidade passa a se relacionar com o mercado, incorporando valores da sociedade moderna, ou terá que $\mathbf{e}$ transformar, isto é, adquirir novos códigos, novas funções, para alcançar o consumidor desta sociedade. Enquanto produto de relações sociais, econômicas e culturais específicas, o artesanato sofre, necessariamente, transformações, à medida em que passam a existir relações com o mercado. 


\section{REFERÊNCIAS BIBLIOGRÁFICAS}

ALMEIDA, A.W.B. de. Quebradeiras de coco babaçu: identidade e mobilização. São Paulo: Ed. Estação Publicidade e Marketing, 1995. 200p.

ADAMS, C. Caiçaras da Mata Atlântica: pesquisa científica versus planejamento e gestão ambiental. São Paulo: Editora Annablume - FAPESP, 2000. $336 \mathrm{p}$.

ALVIM, M.R.B. Artesanato, tradição e mudança : um estudo a partir da "arte do ouro", de Juazeiro do Norte. In: RIBEIRO, B.(Org.). O artesão tradicional e seu papel na sociedade contemporânea. Rio de Janeiro: FUNARTE, 1984. $164 \mathrm{p}$.

BALLÉE, W. Biodiversidade e os índios amazônicos. In: CASTRO, E.V.; CUNHA, M.C. (Org.). Amazônia, etnologia e história indígena. São Paulo: Ed. NHII/USP/ FAPESP, 1993.

BECKER, H.S. Métodos de pesquisa em Ciências Sociais. São Paulo: Editora Hucitec, 1993. 175p.

BEHR, M.V. O desenvolvimento sustentável das populações tradicionais. In: ENCONTRO INTERNACIONAL E EXPOSIÇÃO DE ARTESANATO. Rio de Janeiro, 1994. Anais, Rio de Janeiro, 1994. p.121-129.

BORN, G.C.C. Comunidades Tradicionais na Estação Ecológica da Juréia-Itatins: biodiversidade e medicina popular. In: CONGRESSO NACIONAL SOBRE ESSÊNCIAS NATIVAS, 2., São Paulo, 1992. Anais. São Paulo, 1992. p.804807.

BRANDÃO, C.R. Pesquisa participante. São Paulo: Brasiliense, 1981. 211p. 
BRANDÃO, C.R. Repensando a pesquisa participante. São Paulo: Brasiliense, 1984. 250p.

BRAVERMAN, H. Trabalho e capital monopolista: a degradação do trabalho no século XX. Rio de Janeiro: Guanabara, 1987. 379p.

CALVENTE, M.C.M.H. No território do azul marinho: a busca do espaço caiçara. São Paulo, 1987. 148p. Dissertação (M.S.) - Faculdade de Filosofia Letras e Ciências Humanas, Universidade de São Paulo.

CANCLINI, N.G. As culturas populares no capitalismo. São Paulo: Brasiliense, 1982. $150 \mathrm{p}$.

CÂNDIDO, A . Os parceiros do Rio Bonito. São Paulo: Livraria Duas Cidades, 1987. 284p.

CANELADA, G.V.M. ; JOVCHELEVICH, P. Manejo agroflorestal de populações tradicionais na Estação Ecológica Juréia-Itatins. In: CONGRESSO NACIONAL SOBRE ESSÊNCIAS NATIVAS, 2., São Paulo, 1992. Anais. São Paulo, 1992. p.913-919.

COUTO, A.T. Artesanato: uma estratégia de sobrevivência da agricultura familiar.

In: CONGRESSO DE ECONOMIA E SOCIOLOGIA RURAL, 36., Poços de Caldas, 1998. Anais. São Paulo, 1998. p.911-920.

D’AVILA, J.S. O artesão tradicional e seu papel na sociedade contemporânea. In RIBEIRO, B. (Org.). O artesão tradicional e seu papel na sociedade contemporânea. Rio de Janeiro: FUNARTE, 1984. 164p.

DIEGUES, A.C.S. Pescadores, camponeses e trabalhadores do mar. , São Paulo: Ática, 1983. 287p.

DIEGUES, A.C.S. Desenvolvimento sustentável ou sociedades sustentáveis: crítica dos modelos aos novos paradigmas. São Paulo em Perspectiva, v. 6, n.01/02, p.22-29, 1992.

DIEGUES, A.C.S. Povos e mares: uma retrospectiva de sócio-antropologia marítima. São Paulo: USP/NUPAUB, 1993. 206p.

DIEGUES, A.C.S. O Mito moderno da natureza intocada. São Paulo: USP/NUPAUB, 1994. 156p. 
DIEGUES, A.C.S. ; NOGARA, P.J. O nosso lugar virou parque. São Paulo: USP/NUPAUB, 1994. 187p.

FRANÇA, A. A Ilha de São Sebastião. Estudo de Geografia Humana. São Paulo, 1954. 196p. Dissertação (M.S.) - Faculdade de Filosofia, Letras e Ciências Humanas, Universidade de São Paulo.

FREIRE, P. Criando métodos de pesquisa alternativa. In: BRANDÃO, C.R. Pesquisa participante. São Paulo: Brasiliense, 1981. p.34-41.

HEYE, A.M. Repensando o artesanato: algumas considerações. In: RIBEIRO, B. (Org.). O artesão tradicional e seu papel na sociedade contemporânea. Rio de Janeiro: FUNARTE, 1984. 164p.

LUCHIARI, M.T.D.P. Caiçaras, migrantes e turistas: a trajetória da apropriação da natureza no litoral norte paulista (São Sebastião - Distrito de Maresias). Campinas, 1992. 185p. Dissertação (M.S.) - Instituto de Filosofia e Ciências Humanas, Universidade Estadual de Campinas.

MARCÍLIO, M.L. Caiçara, terra e população: estudo de demografia histórica e da história social de Ubatuba. São Paulo: Edições Paulinas/CEDHAL, 1986. $246 \mathrm{p}$.

MARQUES, J.G.W. Pescando pescadores. São Paulo: USP/NUPAUB, 1995. $304 \mathrm{p}$.

MARQUESINI, M.; PINHEIRO, L.A.F.V.; ARMELIN, M.J.C. Ocorrência de caixetais no município de São Sebastião/S.P. Piracicaba:. USP/ESALQ, 1996. 23p. (Relatório de Pesquisa para o Projeto Caixeta)

MARQUESINI, M.; VIANA, V.M.; LÚCIO, M. J. Revisão participativa no aprimoramento da legislação sobre caixeta (Tabebuia cassinoides) no Estado de São Paulo. São Paulo: Florestar Estatístico, 1999 /no prelo/

MARQUESINI, M.; BERNHARDT, R.; VIANA, V.M.;PAULO, A.R. Potencial de produção e prioridades para a conservação de caixetais no sudeste brasileiro. Piracicaba, ESALQ/USP, 1999. 19p. (Relatório de Pesquisa para o Projeto Caixeta) 
MARX, K. Divisão do trabalho e manufatura. In: MARX, K. O Capital. São Paulo: Ed. Difel, 1982. v.1: Divisão do trabalho e manufatura. p. 386-411.

MEIER, P. El artesano tradicional y su papel en la sociedad contemporánea. Revista del CIDAP - Artesanias de América. v. 12, p.3-21, 1982.

MILANELO, M. Comunidades tradicionais do Parque Estadual da Ilha do Cardoso e a ameaça do turismo emergente. In: CONGRESSO NACIONAL SOBRE ESSÊNCIAS NATIVAS, 2., São Paulo, 1992. Anais. São Paulo, 1992. p.11091111.

MUSSOLINI, G. Ensaios de antropologia indígena e caiçara. São Paulo: Paz e Terra, 1980. 290p.

NOFFS, P.S. Os caiçaras de Toque-Toque Pequeno. São Paulo, 1988. 112p. Dissertação (M.S.) - Faculdade de Filosofia Letras e Ciências Humanas, Universidade de São Paulo.

NOLASCO, A.M. Minimização e aproveitamento de resíduos florestais da Mata Atlântica: o caso da caixeta - tabebuia cassinoides (Lam.) DC. Piracicaba, 2000. 162p. Tese (Doutorado) - Escola Superior de Agricultura Luiz de Queiroz, Universidade de São Paulo.

PARANÁ. Secretaria de Estado e Ação Social e Secretaria de estado da Cultura Desvendando o artesanato: uma contribuição para o Programa de Artesanato Paranaense. Curitiba, 1994. 30p.

PEREIRA, C.J.C. O artesanato na Bahia: fundamentos para o estudo da atividade artesanal em face dos fatores que o condicionam ou influenciam. Salvador: Senai, /195?/

PEREIRA, C.J.C. Artesanato: definições, evolução e ação do Ministério do Trabalho; o programa nacional de desenvolvimento do artesanato. Brasília: MTB, 1979. $153 \mathrm{p}$.

PINHEIRO, L.A.F.V. ; ARMELIN, M.J.C. Levantamento de caixetais do município de São Sebastião. São Paulo: USP/NUPAUB, 1996.24p. 
RIBEIRO, B.G. Artesanato indígena: para quê, para quem? In: RIBEIRO, B. G. (Org.) O papel do artesão na sociedade contemporânea. Rio de Janeiro: FUNARTE, 1984. 164p.

RIBEIRO, B.G. Ao vencedor as batatas! In: RIBEIRO, D. Falas, reflexões e memórias. v.4, n.9, p.113-121, 1993.

RIBEIRO, B.G. A contribuição dos povos indígenas à cultura brasileira. In: SILVA, A.L. ; GRUPIONI, L.D.B. (Org) A temática indígena na sala de aula. Brasília, MEC/MARI/UNESCO, 1995.

RIBEIRO, D. O Povo Brasileiro. São Paulo: Companhia das Letras, 1995. 470p.

SANCHES, R.A. Caiçaras e Estação Ecológica da Juréia- Itatins (litoral sul de São Paulo). São Paulo, 1997. 209p. Dissertação (M.S.) - Instituto de Biociências Universidade de São Paulo.

SATRIANI, L.M.L. Antropologia cultural e análise da cultura subalterna. São Paulo: Ed. Hucitec, 1986.162p.

SACHS, I. Estratégias de transição para o século XXI. In: BURSZTYN, M. (Org.) Para pensar o desenvolvimento sustentável. São Paulo: Ed. Brasiliense, 1993. p. $29-56$

SERVETTO, M. La artesania en la zona Andina Argentina: propuestas para el desarrollo. Córdoba: Servicio de Publicaciones de la Universidad de Córdoba, 1998. $104 \mathrm{p}$.

SIQUEIRA, P. Genocídio dos Caiçaras. São Paulo: Ed. Massao-Ono, 1984. 104p. VIANA, M.V. Perspectivas para a Certificação Sócio-ambiental (selo verde) e Manejo da Caixeta(Tabebuia cassinoides). Florestar Estatístico, v.3, n.8, p. 14 a 20, jul/out.1995.

VIANNA, L.P. ; BRITO, M.C.W. Vila de Picinguaba: o caso de uma comunidade caiçara no interior de uma área protegida. In: CONGRESSO NACIONAL SOBRE ESSÊNCIAS NATIVAS, 2., São Paulo, 1992. Anais, São Paulo, 1992. p.1067-1073. 
VIVES, V. de. A beleza do cotidiano. In: RIBEIRO, B.(Org.). O artesão tradicional e seu papel na sociedade contemporânea. Rio de Janeiro: FUNARTE, 1984. 164p. 